UNIVERSIDADE DE SÃO PAULO

FACULDADE DE FILOSOFIA, LETRAS E CIÊNCIAS HUMANAS

DEPARTAMENTO DE LETRAS CLÁSSICAS E VERNÁCULAS

PROGRAMA DE PÓS-GRADUAÇÃO E, FILOLOGIA E LÍNGUA PORTUGUESA

CAROLINE CALDERON REZAGLI

\title{
O PORTUGUÊS CULTO FALADO POR ALEMÃES RESIDENTES NA CIDADE DE SÃO PAULO: GRAMATICALIZAÇÃO E CONTATO ENTRE LÍNGUAS
}


UNIVERSIDADE DE SÃO PAULO

FACULDADE DE FILOSOFIA, LETRAS E CIÊNCIAS HUMANAS

DEPARTAMENTO DE LETRAS CLÁSSICAS E VERNÁCULAS

PROGRAMA DE PÓS-GRADUAÇÃO E, FILOLOGIA E LÍNGUA PORTUGUESA

\section{O PORTUGUÊS CULTO FALADO POR ALEMÃES RESIDENTES NA CIDADE DE SÃO PAULO: GRAMATICALIZAÇÃO E CONTATO ENTRE LÍNGUAS}

Dissertação apresentada ao Programa de Pós-
Graduação em Filologia e Língua Portuguesa do
Departamento de Letras Clássicas e Vernáculas da
Faculdade de Filosofia, Letras e Ciências Humanas da
Universidade de São Paulo, para a obtenção do título
de Mestre em Letras.

Orientadora: Profa. Dra. Maria Célia Lima-Hernandes

São Paulo

2009 
BANCA EXAMINADORA

\author{
Profa. Dra. Maria Célia Lima-Hernandes \\ (orientadora) \\ USP
Profa. Dra. Vânia Cristina Casseb-Galvão UFG
(titular)
Profa. Dra. Maria Helena de Moura Neves MACKENZIE/UNESP-Araraquara (titular)
Profa. Dra. Patrícia de J. Carvalhinhos USP
(suplente)
Prof. Dr. Maria Angélica Furtado
UFRN
(suplente)
Prof. Dr. Osvaldo Ceschin
USP




\section{Agradecimentos}

À minha orientadora Maria Célia Lima-Hernandes, grande incentivadora para o desenvolvimento de minha pesquisa, por sua paciência, dedicação e carinho.

À profa. Dra. Vânia Casseb Galvão e à profa. Dra. Maria Helena de Moura Neves pela leitura, análise e sugestões apresentadas no exame de qualificação.

Aos meus pais Carmen e Wilson, e ao meu irmão Eduardo, que sempre estiveram ao meu lado me incentivando e vibrando a cada uma de minhas conquistas.

À minha prima Laís, por seu carinho e sua gentileza ao me auxiliar no Abstract.

À querida e saudosa D. Priska pelas aulas de alemão, por toda a ajuda durante meus estudos, pelo carinho e amizade.

Ao Sr. Klaus por suas colaborações durante as aulas de alemão, pela colaboração nas traduções para o desenvolvimento de minha pesquisa e por sua disponibilidade para me ajudar sempre que precisei.

A todos os informantes que colaboraram com suas entrevistas para a produção deste trabalho. 


\section{Resumo}

O presente trabalho apresenta a análise de orações que contêm a preposição para acompanhada de verbos no infinitivo (para+infinitivo), iniciando orações subordinadas em discursos proferidos por alemães residentes em São Paulo, com o intuito de estabelecer se todas as orações, de fato, constituem a ideia de finalidade, ou se apresentam diferentes valores semânticos. O corpus é constituído por ocorrências retiradas de entrevistas com os referidos alemães feitas por mim. São entrevistas de caráter informal sem tema preestabelecido. A estrutura para+infinitivo foi utilizada em contextos semânticos que põem em dúvida seu valor de finalidade, sendo ambíguos ou apresentando desbotamento semântico. Esses outros sentidos, mais abstratos, indicam um processo de gramaticalização na língua portuguesa falada por esses alemães. A estrutura final na língua alemã apresenta variações: um...zu e damit. Além dessas estruturas, a forma zu+verbo no infinitivo responsável, segundo o Hochdeustch (alemão padrão), por indicar verbos no infinitivo, simplesmente, ou orações subordinadas reduzidas de infinitivo, também se apresentou em contextos que geraram dúvidas quanto à sua significação, sendo, por isso, considerada ambígua. Esse fato apontou para um processo de gramaticalização também na língua alemã. Por haver mais de um elemento na língua alemã traduzido para a língua portuguesa com o significado da preposição para, utilizei traduções (para o alemão) do corpus, bem como dados retirados de blogs alemães e jornais digitais alemães, a fim de estabelecer comparações para o desenvolvimento das análises. Este trabalho, dada sua natureza, pode ser uma relevante contribuição para a compreensão do processo pedagógico de ensinoaprendizagem da língua alemã enquanto L2, demonstrando que pode haver diferentes percepções semânticas de estruturas sintáticas tanto por parte dos alunos quanto dos professores ao produzirem discursos em L1 e em L2.

Palavras-chave: replicação, gramaticalização, contato linguístico, orações finais, contextos semânticos. 


\section{Abstract}

This work presents the analysis of sentences that contain the preposition to (para) accompanied of verbs in the infinitive (to+infinitive), beginning subordinate sentences in speeches uttered by resident Germans in São Paulo, with the intention of establishing if all the sentences, in fact, constitute the idea of purpose, or if they have different semantic values. The corpus is constituted by occurrences that came from interviews with the referred Germans done by me. They are interviews of informal character without a preestablished theme. The structure to+infinitive was used in semantic contexts that question its purpose value, being ambiguous or presenting semantic fading. Those other meanings, more abstract, indicate the grammaticalization process in the Portuguese language spoken by those Germans. The final structure in the German language presents variations: um...zu and damit. Besides those structures, the form $z u+v e r b$ in infinitive, according to Hochdeutsch (pattern German), for indicating verbs in the infinitive, simply, or subordinated sentences reduced of infinitive, also came in contexts that generated doubts about its significance, being, for that, considered ambiguous. That fact appeared for a grammaticalization process also in the German language. For there being more than an element in the German language translated for the Portuguese language with the meaning of the preposition to, I used translations (for German) of the corpus, as well as data of German blogs and German online newspapers, in order to establish comparisons for the development of the analyses. The purpose of this work is to contribute in the pedagogic process of teaching-learning of the German language while L2, demonstrating that there can be different semantic perceptions of syntactic structures not only of the students but also of the teachers when they produce speeches in L1 and in L2.

Keywords: replication, grammaticalization, language contact, final sentences, semantic contexts. 


\section{LISTA DE TABELAS}

página

95

Tabela 1: Padrões funcionais da estrutura - Língua Portuguesa L2

(Polaridade x Função semântica)

Tabela 2: Padrões funcionais da estrutura - Língua Portuguesa L2

96

(Identidade dos sujeitos x Função semântica)

Tabela 3: Padrões funcionais da estrutura - Língua Portuguesa L2

96

(Material interveniente x Função semântica)

Tabela 4: Padrões funcionais da estrutura - Língua Portuguesa L2

97

(Estrutura formal x Função semântica)

Tabela 5: Estruturas alemãs - blogs e jornais

(Polaridade x Função semântica)

Tabela 6: Estruturas alemãs - blogs e jornais

(Identidade dos sujeitos x Função semântica)

Tabela 7: Estruturas alemãs - blogs e jornais

(Material interveniente x Função semântica)

Tabela 8: Estruturas alemãs - blogs e jornais

(Estrutura formal x Função semântica)

Tabela 9: Padrões alemães - informantes

(Polaridade x Função semântica)

Tabela 10: Padrões alemães - informantes

(Identidade dos sujeitos x Função semântica)

Tabela 11: Padrões alemães - informantes

(Material interveniente x Função semântica)

Tabela 12: Padrões alemães - informantes 


\section{SUMÁRIO}

página

RESUMO

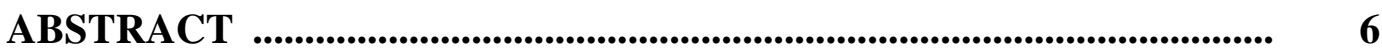

LISTA DE TABELAS $\quad$........................................................................... 7

INTRODUÇÃ $\quad$......................................................................................... 10

Capítulo 1: FUNDAMENTAÇÃ̃ TEÓRICA

1. Gramaticalização e Replicação ......................................................... 19

1.1 Processo de Replicação .................................................................. 21

2. Aquisição de L2 …….................................................................... 28

2.1 Relações entre aquisição de L2, pidgin e crioulo .................................

Capítulo 2: GRAMATICALIZAÇÃO E CONTATO LINGUÍSTICO...... 40

1. Gramaticalização e contato línguístico segundo Heine \& Miyashita ......... 40

2. Code - Switching segundo Shana Poplack e a gramaticalização ................... 44

\section{Capítulo 3: ASPECTOS DA HISTÓRIA SOCIAL DA IMIGRAÇÃO}

ALEMÃ: um olhar sobre São Paulo $\quad$.................................................. 49

1. Aspectos histórico-sociais da imigração alemã para o Brasil ...................... 50

2. A imigração na cidade de São Paulo $\quad$..................................................... 60

3. O aspecto linguístico e a relação com a língua portuguesa $\quad$........................ 68 
1. O emprego do infinitivo na língua alemã ........................................... 74

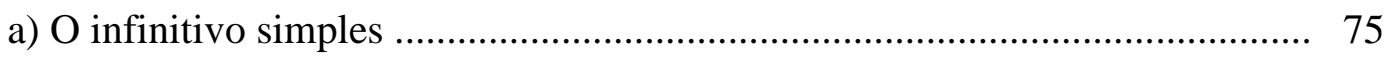

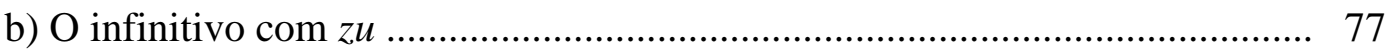

b.1) $u m$... zu: a estrutura para + infinitivo em alemão ............................... 79

c) A preposição $u m$

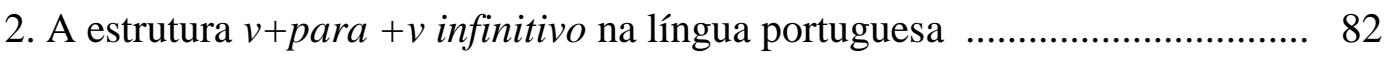

3. A estrutura $v+$ para $+v$ (infinitivo) no discurso de alemães sediados em São Paulo 88

3.1. Análise do corpus em português produzido pelos informantes entrevistados.. 91

3.2. Análise do corpus constituído por elementos retirados do jornal

Deutsch Welle

3.3. Análise da tradução para o alemão do corpus produzido pelos informantes entrevistados

REFERÊNCIAS BIBLIOGRÁFICAS

REFERÊNCIAS ELETRÔNICAS 


\section{Introdução}

A variação linguística é um dos fenômenos mais estudados pelos linguistas por sua importante função de representar a diversidade social dentro das comunidades. Tal diversidade depende de variados fatores para sua manifestação, tais como espaço geográfico, espaço social, espaço temático, espaço temporal e canal linguístico (Castilho \& Preti, 1986).

Restringindo a constituição do corpus a um determinado espaço geográfico ainda restam outros fatores de grande influência na variedade linguística, como a situação e o tema sobre o qual conversam os falantes, o espaço histórico ao qual pertencem (situados em determinado momento histórico: Antiguidade, Era Clássica, Era Moderna ou Contemporânea, por exemplo), o canal linguístico usado pelos falantes (conversa durante um encontro dos falantes, conversa telefônica ou cartas, por exemplo), e o seu espaço social.

O espaço social demarca-se pela estratificação social dos falantes. É bastante comum que linguistas fragmentem esse espaço, para estudo, em dois grupos: os falantes da variedade popular e os da variedade culta. Os indivíduos são, então, distribuídos nesses dois grupos segundo razões políticas, econômicas e culturais, ou seja, segundo seu papel de maior ou menor prestígio social. Em verdade, as duas variantes em questão não possuem entre si um grande distanciamento, principalmente porque a comunidade - tão dinâmica - revela-se heterogênea.

A variação tem sido fortemente estudada por linguistas que tomam a L1 como alvo da investigação. Existem âmbitos de variação, no entanto, que fogem a essa esfera de questionamentos. Com a migração intensa, a globalização acentuada, as interações 
virtuais cada vez mais abrangentes, as reuniões por videoconferência, os intercâmbios cada vez mais incentivados, uma visão multicultural que valoriza as experiências de internacionalização providenciam que estudantes, executivos, especialmente, assumam uma vida nova em países sociolinguisticamente diversos. Assim, falar em variação nesse contexto de produção pode suscitar alguns debates bastante interessantes, já que os produtores dessas mesmas falas, ainda que não dominem completamente a línguameta, são considerados falantes cultos pela comunidade.

Durante meu curso de graduação em Letras pela Universidade de São Paulo, houve a proximidade com professores alemães ministrantes de disciplinas como "Língua alemã”, "Linguística alemã" e "Literatura alemã". Muitos desses professores estavam baseados em universidades estrangeiras e atuavam na Universidade de São Paulo na condição de convidados, situação em que permaneciam por, aproximadamente, cinco anos. Alguns apresentavam maior domínio da língua portuguesa que outros. No decorrer das aulas e em conversas com esses professores, era comum perceber alguns “desvios" fonéticos, sintáticos e morfológicos que produziam em suas falas e, muitas vezes, ficava nítido que muitos desses desvios eram "empréstimos" linguísticos de sua língua materna, razão pela qual farei referência a eles como 'interferências', que considero muito mais adequado ao fato linguístico em si. Estava identificada, então, mais uma variante da língua portuguesa, aquela produzida por alemães.

Ao término de meu curso de graduação, ministrei, por um ano, aulas de língua alemã no "Centro de Línguas" da Prefeitura do Município de Jundiaí. As duas salas de aula nas quais trabalhei eram compostas por, aproximadamente, vinte alunos de idades e níveis de escolaridade variados. No entanto, pude notar que todos eles, sem exceção, também revelavam algumas interferências ao produzir discursos (orais e escritos) em 
língua alemã e, tal qual o processo identificado na fala dos professores alemães da Universidade de São Paulo, eram casos que poderiam ser considerados frutos de empréstimos linguísticos de sua língua materna, a língua portuguesa.

Numa situação de ensino-aprendizagem de língua estrangeira, é muito comum que os alunos façam, mesmo que mentalmente, uma correlação entre sua língua materna (língua-fonte) e a língua a ser apreendida (língua-meta) para, dessa forma, tentar compreender a estrutura da L2. Isso ocorre, pois a maioria dos alunos adultos e jovens que possuem um conhecimento da gramática de sua língua materna, ainda que esse conhecimento seja internalizado, necessitam racionalizar e entender sobre o funcionamento da L2. Acreditam que somente assim conseguirão assimilá-la e reproduzi-la. Esse é um comportamento intrínseco aos adultos e jovens, mas não ocorre numa situação em que os alunos são crianças.

A seguir, cito algumas das interferências identificadas na produção de meus alunos:

(1) (...), weil wenig Leute $\underline{\text { es }}$ da gibt. - a maioria das conjunções alemãs mudam as estruturas que introduzem. A conjunção subordinativa "weil" faz com que o verbo flexionado seja colocado no final da oração, porém o elemento sintático sujeito, permanece em sua posição, aparecendo, portanto, logo após "weil". Nesse trecho transcrito, percebe-se que o aluno sabe da regra da mudança estrutural, porém ele ainda apresenta dúvidas sobre onde "encaixar" todos os elementos sintáticos. O correto seria “(...) weil es wenig Leute da gibt” (porque há poucas pessoas).

(2) (...), weil kann man schwimmen und ein Sonnenbad nehmen - nesse exemplo também não houve a construção sintática em conformidade com a gramática alemã, 
para frases iniciadas por "weil". O correto seria “ (...) weil man schwimmen kann und ein Sonnenbad nehmen" (porque você pode nadar tomar sol).

(3) Kann man gut essen in Restaurant gut Meeresfrüchte. (pode-se comer bons frutos do mar no restaurante) - nesta frase, a partícula "man", que tem a função de índice de indeterminação do sujeito, deveria iniciar a oração segundo a gramática normativa alemã, já que se trata de uma afirmação. O correto nesse caso, então, seria "Man kann gut essen (...)”. No entanto, segundo a gramática normativa da língua portuguesa, não é correto iniciar uma frase com a partícula "se", mas sim com o verbo ao qual se "liga". Os três trechos a seguir, recolhidos de textos produzidos por alunos diferentes, evidenciam e reforçam tal hipótese de interferência entre línguas.

(4) Kann man nach Ubatuba mit dem Auto oder mit Bus fahren. - neste trecho, além do desvio já identificado anteriormente, há uma outra ocorrência: o não-preenchimento de um artigo após a preposição "mit”, que é obrigatória em alemão, porém o seu correspondente em português não o seria. Isso permitiria a realização de "Pode-se ir para Ubatuba de carro ou de ônibus".

(5) Deshalb dort kann man im Meer Schwimmen, oder Kontakt mit der Natur haben (...) - o advérbio conjuntivo "deshalb" muda a estrutura da oração que introduz, fazendo com que o verbo coloque-se à sua direita, ou seja, antes do sujeito ("man"). Em português, no entanto, seria possível a realização de "Por isso lá se pode nadar no mar". A frase transcrita, então, indica replicação ${ }^{1}$ da língua portuguesa.

(6) Man kann essen in Hotel, (...) (pode-se comer no hotel) - na língua portuguesa, usase o verbo com função auxiliar posicionado em posição anterior à do verbo principal como em "pode-se comer", “quero falar" e "deve-se fazer". Em alemão, no entanto, o

\footnotetext{
${ }^{1}$ Replicação deve ser, aqui, compreendida como uma transferência de significados gramaticais e/ou estruturas gramaticais entre duas línguas em situação de contato. Esse fenômeno proposto por Heine \& Kuteva será alvo de discussão mais aprofundada no capítulo I (Fundamentação Teórica).
} 
verbo com função auxiliar (nesse trecho é o verbo modal "kann”) é conjugado e ocupa a segunda posição em uma oração afirmativa, mas o verbo principal ("essen") deve vir ao final da frase em sua forma infinitiva. Fica clara a replicação do uso regular da língua portuguesa nessa frase.

(7) Du wünschst eine Nachspeise? (Você quer um prato de comida?) - O sujeito ("du") usado para iniciar uma oração, mesmo que esta seja interrogativa, é descrito pela norma da língua portuguesa. Na gramática alemã, diversamente, consta que toda oração interrogativa deve ser iniciada pelo verbo (no caso, "wünschst”). Daí, conclui-se que houve, nesse trecho, uma replicação da língua portuguesa.

Toda essa "mistura" de elementos entre as duas línguas, portuguesa e alemã, despertou meu interesse em pesquisar e estudar mais detalhadamente quais os processos envolvidos na produção dessa nova língua que surge do entrelaçamento entre L1 e L2. Decidi, então, por estudar a fala de alemães nativos, cultos, falantes do português e residentes na cidade de São Paulo. Esses foram os critérios suficientes para a seleção dos informantes que produziriam as respostas durante as entrevistas formuladas.

A busca pelos informantes começou através de uma pesquisa no site do Consulado alemão de São Paulo. Coletei algumas informações a respeito de entidades e associações alemãs, como clubes, igrejas e escolas.

O primeiro contato foi feito com pesquisadores alemães que trabalham no Instituto Martius Staden, na cidade de São Paulo, os quais demonstraram extrema gentileza ao participar das entrevistas. Em seguida visitei instituições religiosas, cujos dirigentes auxiliaram-me no contato com alguns de seus membros. A partir de então, com a ajuda de todos os informantes, contatados graças a uma rede de indicações de amigos e parentes, pude registrar 15 entrevistas. 
Cada entrevista foi transcrita para, então, propiciar um estudo mais detido dos efeitos gramaticais decorrentes do contato entre as duas línguas: o português brasileiro e o alemão.

A seguir, identifico algumas das interferências produzidas por esses informantes no momento da interação linguística em língua portuguesa.

No exemplo (8), a conjunção "se" foi empregada num contexto em que um nativo usaria o advérbio temporal "quando". Essa substituição ocorreu, provavelmente, por replicação da palavra wenn, que é usada nos dois tipos de contextos na língua alemã, com valor de "se" e com valor de "quando". No exemplo (9), essa substituição de "quando" por "se" é percebida mais claramente.

(8) (...) não... foi muito difícil porque... se eu chego aqui, eu não fala um palavra em português, né... eu só fala alemão... (informante 3).

(9) Se Mário trabalhou no Iraque, ela escreveu muitas cartas para ele. (informante 4)

Em alemão (no estilo formal ou informal), o item verbal "existir", "Es gibt”, nunca é substituído pelo verbo "ter", "haben", como acontece no português do Brasil. No entanto, encontrei muitas ocorrências de "ter" em lugar de "haver" nas falas, em português, de alguns de meus informantes alemães, como pode ser lido no exemplo seguinte. Esse uso adequado ao falar do português brasileiro, portanto, pode ser considerado um índice de maior fluência na L2.

(10) (...)porque tem muitas coisas positivas na Alemanha ... com certeza ... tem coisas negativas também (...)(informante 3).

Algo que chama a atenção em relação às transferências é uma grande dificuldade em estabelecer quais preposições usar em certos contextos. Em alguns momentos ocorre 
o uso "estranho" e, em outros, também ocorre o apagamento dessas estruturas, como demonstro nos exemplos (11) a (14):

(11) (...) acho que nosso dever é de aprender dos nossos erros e de nossos antepassados (...)(informante 4).

(12) Não de avaliar ... até que ponto obtive sucesso (...)(informante 3).

(13) Nasceu na volta do ano de 1630 (informante 4).

(14) (...) ele faleceu $\Phi 1675$ em Marne(...)(informante 4).

Num contexto como o apresentado em (15), um nativo poderia produzir em seu discurso "continuava a usar" ou, geralmente, "continuava usando". A utilização da preposição "de" antes de um verbo no infinitivo demonstra, de forma bastante nítida, a transposição do infinitivo preposicionado alemão " $z u+v$ infinitivo” para a estrutura infinitiva do português.

(15) (...) ele continuava de usar a marca de identificação (...)(informante 4).

Em alguns contextos específicos, que serão descritos na seção 3.1, o infinitivo alemão pode ser formado utilizando-se a preposição "zu”, que é um uso aproximado do correspondente à preposição "de" do português, antes do verbo. A tradução de uma estrutura infinitiva preposicionada alemã como “Allein ins Kino zu gehen, hatte ich keine Lust" ou "Er hat angefangen zu weinen" seria, respectivamente, "Ir ao cinema sozinho, eu não tive vontade" ou "Ele começou a chorar".

Como demonstrei, são comuns as transferências entre L1 e L2, mas há uma que se revela mais produtiva nas interlínguas (português L2 - alemão L1) sob análise: tratase da estrutura $v+$ para $+v$ infinitivo. Tomando essa estrutura como objeto de estudo, viso a responder questionamentos acerca do estatuto dessa transferência à luz de pressupostos teóricos da gramaticalização associados à aquisição de L2, via contato 
linguístico. Trata-se mais especificamente da descrição da replicação de padrões de usos nas interlínguas do português faladas em São Paulo por informantes alemães.

Para tanto, inicio o trabalho apresentando conceitos acerca do processo de gramaticalização de uma língua e da aquisição de segunda língua (L2). Pela própria necessidade de se construir um espaço de diálogo entre áreas segmentadas na maioria dos estudos que envolvem gramaticalização, obrigatoriamente tratarei de conceitos derivados dessa interface, quais sejam, o estatuto de pidgin, do processo de crioulização, de interlínguas, de code-switching e de empréstimo. Dessa forma, tenho condições de providenciar um diálogo interessante entre gramaticalização e aquisição L2 via contato linguístico, esteio teórico deste estudo.

Em seguida, apresento a sistematização das informações resenhadas a partir de estudos sobre o tema da imigração alemã no Brasil, mais especificamente na cidade de São Paulo. Essas informações serão relevantes para a compreensão dos contatos linguísticos estabelecidos e das interlínguas relatadas como derivadas desse primeiro contato com o povo paulista, o que também se prestará como aspectos sociolinguísticos relevantes na formação de um português culto nessa cidade, num recorte baseado na comunidade imigrante alemã.

No capítulo seguinte, descrevo o emprego da estrutura $v+$ para $+v$ infinitivo nas duas línguas, portuguesa e alemã, as ocorrências dessa estrutura nas interlínguas produzidas por alemães em situação de interação em português.

As discussões tecidas durante a seção 3 do Capítulo 4 apontaram para a necessidade de que eu adotasse uma estratégia preventiva: a composição de uma amostra de controle feita com os imigrantes estáveis habitantes da cidade São Paulo. 
Essa é uma necessidade que se consubstancia nas situações de contato e de aprendizagem da língua portuguesa aqui relatadas.

No entanto, para que a análise fosse mais completa, Analisando o corpus e a base teórica de meu trabalho, percebi que não seria possível identificar indícios de um possível processo de replicação da L1 para a L2 somente com as ocorrências produzidas em português. Dessa forma, constituí nova amostra de controle a partir de língua escrita por alemães nativos, para que eu pudesse estabelecer uma comparação mais adequada. 


\section{Capítulo I}

\section{Fundamentação teórica}

Neste capítulo, organizo as informações teóricas que darão suporte à pesquisa que desenvolvo. A partir das discussões que serão tecidas durante a apresentação dessas informações, terei condições de explicitar, de forma mais clara, os pressupostos teóricos que refuto, dada sua incompatibilidade com os encaminhamentos e mesmo com os questionamentos que movem meus passos para sua elucidação; ao mesmo tempo, darei relevo aos pressupostos que funcionarão como sustentáculo desta pesquisa.

\section{Gramaticalização e Replicação}

O conjunto de estudos sobre a gramaticalização revela diferentes linhas téoricas e metodológicas, porém a maioria dos estudiosos a toma como um processo que pode ser apreendido em sincronia, em diacronia ou em pancronia.

Meillet (1912) foi quem cunhou o termo e quem primeiro discutiu-o como atinente a um processo diacrônico no qual ocorreria a passagem de uma estrutura pertencente a uma categoria lexical plena (nomes, verbos e adjetivos) a uma categoria gramatical (preposição, advérbios e auxiliares). Essa ideia ganhou eco em muitas vozes da segunda metade do século XX, dentre as quais cito as de Traugott \& Heine (1991): "the evolution of grammatical forms (...) out of earlier lexical forms $(\ldots)^{2,}$.

Durante a segunda metade do século e, de modo mais acentuado, no século XXI, no Brasil, vários pesquisadores puderam demonstrar, por meio de descrições

\footnotetext{
${ }^{2}$ Pode ser traduzido como: "a evolução de formas gramaticais a partir de formas lexicais".
} 
linguísticas criteriosas que gramaticalização pode ser compreendida como mais abrangente e, dessa forma, não somente pode ser correlacionada à evolução de palavras (Lima-Hernandes, 2005; Barroso, 2008; Batista, 2008; Spaziani, 2008), mas ainda pode ser correlacionado à evolução de combinação de orações (Neves \& Braga, 1998; LimaHernandes, 1998; Braga, 1999; Dias, 2001; Gonçalves, 2003; Casseb-Galvão, 2007; Sartin, 2008) e de estruturas/construções (Casseb-Galvão, 1999; Lima-Hernandes, 2008; Defendi, 2008).

Heine, Claudi e Hünnemeyer (1991) descrevem o processo de gramaticalização como sendo mais abrangente que os definidos por seus antecessores. Para eles, o mundo real serve como fonte ou motivação para que se deflagre o processo. As chamadas fontes estão relacionadas às experiências humanas mais básicas, que derivam das atividades físicas e dos comportamentos rotinizados pelo homem.

As fontes escolhidas fornecem referências concretas para que se possa entender e referir conceitos abstratos. Geralmente são partes do corpo, fenômenos da natureza, itens relacionados aos seres humanos (pai, pessoa, criança), verbos de movimento, verbos que indicam postura, verbos de processo mental (pensar) e quantificadores. $\mathrm{O}$ paralelo é que os itens-fonte também expressam os estados e processos mais básicos da experiência humana, tais como o espaço físico ("estar em”), de movimento ("move-se para"), de atividade ("faz tal coisa"), de parte-todo (“é parte de”), de equação (“é como um...") e de caráter comitativo (“está com”).

Segundo Heine, Claudi e Hünnemeyer (1991), uma palavra pode sofrer uma movimentação em relação ao seu uso, porém tal movimentação pode ser tão pequena que a palavra não chega a sofrer alteração em sua categoria. Essa movimentação da fonte para o alvo (a nova estrutura gramatical em que o item-fonte se transforma) é 
unidirecional e tem como consequência a alteração semântica gradativa da fonte até que, em caso de processo que se demonstre mais extremo, se mantenha apenas seu conteúdo gramatical.

Essa movimentação unidirecional também é chamada de abstratização (Heine, Claudi e Hünnemeyer, 1991) e pode ser representada pelo encadeamento das castegorias cognitivas: pessoa $>$ objeto $>$ processo $>$ espaço $>$ tempo $>$ qualidade, reformulado por Lima-Hernandes (2008) da seguinte maneira: pessoa > objeto > atividade > espaço > tempo $>$ processo $>$ qualidade ${ }^{3}$.

Numa situação de contato linguístico, determinadas partes que compõem a estrutura de uma língua tendem a ser afetadas e modificadas por influência de outra língua através de um processo de transferência de dados entre as línguas. Argumentam a favor dessa tese Heine \& Kuteva (2006), que defendem ser possível a transferência de significados gramaticais e/ou estruturas gramaticais entre duas línguas em situação de contato. A esse fenômeno os autores chamaram de replicação.

Tendo em vista a importância desse fenômeno para a compreensão do que ocorre em situação de contato linguístico, tratarei da replicação de modo mais detido.

\subsection{Processo de Replicação}

Heine \& Kuteva (2006) vivenciaram experiências de contato linguístico sem intermediação do ensino formal. Da mesma forma, orientaram trabalhos que reforçaram suas intuições acerca dos efeitos de uma língua sobre a outra em situação comunicativa.

\footnotetext{
${ }^{3} \mathrm{O}$ argumento para essa alteração é que a categoria PROCESSO tem em sua base a categoria de TEMPO, o que impede que esta esteja representada mais à direita da primeira no continuum.
} 
A novidade desses trabalhos, diferentemente dos primeiros trabalhos ${ }^{4}$ de caráter constrastivo que focalizam as interferências no léxico e na fonologia, é que demonstram a invalidade de um axioma linguístico: a gramática estaria imune a esses tipos de interferências. Assim como ocorre no trabalho de Heine \& Kuteva, meu principal interesse é a replicação gramatical sem, contudo, me deter na investigação das implicações que essa replicação possa gerar às línguas a partir das interlínguas. Concentro-me, com exclusividade, em identificar os pontos frágeis da gramática, afetados pelo contato linguístico entre português-alemão em espaço paulista.

Os mais recentes estudos desenvolvidos no século XXI relatam que a gramática não está imune às replicações, por isso Heine e Kuteva (2006:1) passam a defender que

a transferência de sentidos e estruturas gramaticais em contextos translinguísticos é comum e (...) não seria uma transferência aleatória, mas esculpida por processos gramaticais de mudança linguística (...); esse processo de transferência está essencialmente de acordo com os princípios da gramaticalização.

Os tipos de materiais linguísticos que geralmente sofrem replicação, segundo Heine \& Kuteva, são: forma (sons ou combinações de sons); significados (incluindo significados ou funções gramaticais) ou combinações de significados; unidades de forma-significado ou combinações de unidades de forma-significado; relações sintáticas (a ordem de elementos significativos); e qualquer outra combinação entre os itens anteriores.

A replicação gramatical tem como condição necessária de manifestação um grau acentuado de bilinguismo extensivo (uma comunidade precisa se comunicar em L2 cotidianamente) ou de bilinguismo intensivo (um indivíduo é exigido, na L2, em

\footnotetext{
${ }^{4}$ Desde a década de 50 do século XX, linguistas se dedicam a estudar o contato linguístico. Um trabalho relevante desse período pode ser ilustrado por Weinreich ([1953] 1964, apud HEINE \& KUTEVA, 2005)
} 
situações diárias de interação). O primeiro caso pode ser ilustrado com o caso do Canadá ou mesmo dos kamaiurás, no Alto Xingu, em que invariavelmente precisam se comunicar numa segunda língua. O segundo caso pode ser ilustrado pelo tipo de comunidade que investigo neste trabalho: alemães que, sem intenção de imigração definitiva, precisam travar contato com a L2 em várias situações cotidianas.

As variáveis que podem desencadear tal replicação gramatical durante o contato linguístico, são muitas. Heine \& Kuteva (2006: 35) identificam as seguintes:

- $\quad$ a configuração sociolinguística;

- $\quad$ a estrutura da língua modelo;

- $\quad$ a estrutura da língua réplica;

- necessidades e intenções comunicativas;

- $\quad$ valores culturais que caracterizam as comunidades associadas com a língua modelo e língua réplica;

- comportamento criativo ativado para o uso de recursos linguísticos avaliados de novas maneiras.

Está na base de cada uma dessas variáveis a tendência que os falantes têm para desenvolver novas estruturas de expressão gramatical que lhes pareçam mais adequadas em determinadas situações, através da manipulação dos recursos linguísticos disponíveis. Tais estruturas representam novas alternativas para a organização do discurso linguístico. Cada um desses aspectos é explanado por mim no decorrer do desenvolvimento desta pesquisa.

O que se aplica à replicação gramatical em geral parece também se aplicar à cópia do código em geral: "The result of convergent developments due to code copying 
are innovative and creative structures which must be regarded as integral parts of their respective codes", (JOHANSON, apud HeINE \& KUTEVA, 2006: 35).

A replicação constitui-se como o objeto teórico que assumi como o suporte ao que ocorre com o objeto linguístico selecionado inicialmente $(v+$ para $+v$ infinitivo $)$. Mais especificamente, o objeto teórico insere-se no campo das replicações de processos gramaticais nas interlínguas produzidas por alemães em processo de aquisição do português do Brasil.

A replicação gramatical por contato entre línguas, ainda segundo Heine \& Kuteva (id.ib), ocorre quando um elemento gramatical Mx de uma língua M, que servirá como modelo nesse contato, é replicado na língua $\mathrm{R}$ surgindo, assim, uma nova estrutura Rx. No entanto, conforme os estudos dos autores revelam, a estrutura Rx não é inteiramente nova, pois ela é "construída" a partir de uma antiga estrutura Ry existente anteriormente em $\mathrm{R}$ e que a replicação transformou em Rx. Em outras palavras, a replicação não parte de um vazio, ao contrário, ela requer um discurso padrão apropriado na língua $\mathrm{R}$ para tomar lugar ${ }^{6}$.

Ainda Heine \& Kuteva (2006:41) ${ }^{7}$ defendem que cada língua possui padrões de uso gramatical com as seguintes propriedades: a. são associadas com algum sentido gramatical específico; b. há recorrentes pedaços de discurso linguístico, os quais podem

\footnotetext{
${ }^{5}$ A tradução pode ser a seguinte: "O resultado da evolução convergente devido ao código copiado são estruturas inovadoras e criativas que devem ser considerados como parte integrante de seus respectivos códigos".

${ }^{6}$ A esse respeito Heine \& Kuteva (2006: 45) afirmam: "In situations of contact, a minor use pattern (Ry) may develop into a major use pattern $(\mathrm{Rx})$ on the model of another language, where replication has the following effects in particular: (i) An existing use pattern is used more frequently; (ii) It is used in new contexts; (iii) It may become associated with a new grammatical function".

7 As palavras textuais dos autores são as seguintes: "They are associated with some specific grammatical meaning. They are recurrent pieces of linguistic discourse. Such pieces may consist of a clause, a phrase, or even a single form used in some specific context. Their use is optional, that is, they may but need not be employed for the expression of that grammatical meaning. They are the primary units figuring in the initial stage of grammatical replication".
} 
consistir de uma oração, um sintagma ou uma forma simples empregada num contexto específico; c. seu uso é opcional, isto é, podem - embora não necessariamente precisem - ser empregados para expressar um sentido gramatical; d. unidades primárias figuram num estágio inicial de replicação gramatical.

Dado que defendem que a configuração sociolinguística pode explicar essas replicações, deve-se ter em mente que padrões de uso são variáveis frequentemente restritas a camadas sociais específicas dos falantes bem como ao tipo de registro e à região de origem e de habitação dos mesmos. É possível aventar a hipótese de que essas restrições podem ser ativadas a depender do tipo de contato linguístico efetivado/exigido e do papel do falante na comunidade que o recebe como imigrante.

Devido a esse fator sociolinguístico é que nesta pesquisa selecionei informantes de um grupo restrito (alemães cultos falantes do português), que utilizam o português em contextos específicos (não têm a intenção de naturalizar-se).

Existem também condições básicas para identificar a replicação induzida pelo contato, ou seja, os mesmos contextos deflagradores da replicação servem de pistas para a seleção dos dados para o estudo: a produtividade do padrão identificado, diversificação do contexto de emprego desse padrão, opacização do sentido original e alteração da função gramatical original.

O processo de gramaticalização induzido pelo contato, então, remete aos tradicionais parâmetros de gramaticalização: alta recorrência (frequência), extensão (emersão de sentidos gramaticais em novos contextos de emprego), dessemantização (bleaching), recategorização. 
A gramaticalização da réplica, segundo Kuteva (2003, apud Heine \& Kuteva 2005:92), ocorreria da seguinte maneira:

a. os falantes notam que a língua $\mathbf{M}$ tem uma categoria gramatical $\mathbf{M x}$;

b. com base nisso, criam uma categoria equivalente $\mathbf{R x}$ na língua $\mathbf{R}$, usando material avaliado na $\mathbf{R}$;

c. para esse fim, replicam o processo de gramaticalização que assumem tomar lugar na língua $\mathbf{M}$, usando uma fórmula analógica do tipo $[\mathbf{M y}>\mathbf{M x}]:[\mathbf{R y}>\mathbf{R x}]$; e

d. gramaticalizam $\mathbf{R y}$ para $\mathbf{R x}$.

Aplicando esses passos hipotetizados e depois ratificados em pesquisa por Heine \& Kuteva ao objeto linguístico que isolei para estudo, posso pressupor que:

a. os informantes alemães percebem, numa dada situação de contato, que em sua língua materna (alemão) há uma categoria gramatical que parece atender à necessidade comunicativa em português;

b. criam, então, uma categoria equivalente no português, usando o modelo da língua alemã;

c. nesse processamento complexo, transferem para o português uma função mais gramaticalizada da língua alemã, impondo a seguinte fórmula analógica [língua alemã > estrutura $z u+v$ infinitivo] : [português $>v+$ para $+v$ infinitivo];

d. finalmente, replicam na estrutura do português a estrutura imaginada a partir da gramática do alemão como correspondente para aquela situação comunicativa.

Ainda em seu estudo sobre replicação, Heine \& Kuteva (2006:60) já demonstram um indício de gramaticalização da expressão um $z u$. Dizem que essa conjunção complexa "não é usada normalmente para introduzir modelos nominais ou 
adjetivos; no entanto há uma ampla aceitação do uso desse padrão, em que um zu pode ser usado como em ein Messer um Brot zu schneiden (uma faca para cortar o pão). Entre os falantes alemães do sul do Tyrol, norte da Itália, intensamente expostos ao modelo da língua italiana, Riehl (2001:255 apud Heine \& Kuteva, 2006) encontrou tal uso padrão aplicado em contextos nos quais uma interpretação proposta não resulta numa compreensão extensa, e na qual parece emergir uma nova função que introduz frases infinitivas com em (16). Riehl argumenta que a extensão do uso para esse contexto tem sido influenciada pelo italiano, a língua oficial.

(16) Deutsch finde ich ideal, um die Einheitssprache in Europa zu werden.

(Eu acho ideal o alemão tornar-se uma língua homogênea na Europa.)

Dessa maneira a expressão alemã do Tyrol Schwierigkeiten, um Freundschaften zu knüpfen (Dificuldade para fazer amizades), ainda que não seja produzida na variedade padrão da língua alemã, tem como modelo no italiano difficoltà a farsi delle amicizie. Esse processo, segundo os autores, está de acordo com a gramaticalização de marcadores de proposições infinitivas. Nesse caminho, o marcador um zu foi aplicado a novos contextos e, ao mesmo tempo, adquiriu uma função mais geral." (Heine \& Kuteva, 2005: 89).

Dado que, além de fenômeno linguístico, há o fato de se reconhecerem forças derivadas da própria intenção de aprender ou não uma língua, conceitos relativos à aquisição de L2 serão mobilizados para que seja possível cercar eficientemente o fenômeno da replicação, situando-o ou distando-o do que já se conhece nessa área de pesquisa. 


\section{Aquisição de L2}

Nesta seção, é objetivo específico a identificação de pontos que permitam um diálogo produtivo entre o estudo da mudança gramatical, o contato linguístico e o processo de aquisição de L2. Tal diálogo justifica-se porque tanto a aquisição de L2 quanto a gramaticalização derivada de contato linguístico implicam interlínguas e, em consequência, replicações.

A aquisição de segunda língua está intrinsecamente ligada às estratégias de aprendizagem. Estas são, segundo Oxford (1990), “ações conscientes e específicas que cada indivíduo utiliza para tornar seu aprendizado mais efetivo. Portanto, as faculdades que cada indivíduo utiliza para organizar e produzir informações”. Essa definição congrega a ideia de que todas as estratégias mobilizadas para a aprendizagem de línguas são motivadas ou direcionadas para o desenvolvimento da competência comunicativa, a que comumente rotulamos fluência.

As pesquisas sobre as estratégias de aprendizagem de línguas tiveram início nos anos 60, mas começaram a ganhar destaque a partir de 1970 com um trabalho de J. Rubin que consistia na investigação e análise do perfil de bons alunos, quais sejam, aqueles que apresentavam boa desenvoltura e fluência na língua estrangeira. Sua questão central era a identificação de estratégias utilizadas por esses bons alunos para a obtenção de sucesso como falantes de segunda língua. Posteriormente, vários autores desenvolveram estudos científicos sobre o tema.

Atualmente, a maioria dos autores apresenta um consenso quanto aos tipos de estratégias de aprendizagem. Para esse resumo, lançamos mão das informações sintetizadas por Oxford em seu Dicionário: 
1. Estratégias metacognitivas: englobam o pensar sobre o aprendizado. Envolvem ações do próprio aprendiz, como o planejamento, monitoramento da compreensão/produção e a auto-avaliação.

2. Estratégias cognitivas: permitem que o aprendiz entenda e produza a língua de diferentes modos, tais como: a repetição de sons, palavras e orações; produção de resumos; a recombinação de novas estruturas, ou seja, a construção de uma sentença de significado ou expressão mais longa na tentativa de unir uma informação nova àquelas pré-existentes; e o uso da compensação, que permite ao aprendiz usar a língua estrangeira mesmo que ele apresente várias lacunas quanto ao conhecimento dessa língua.

3. Estratégias sócio-afetivas: estão diretamente ligadas às atitudes e motivações do aprendiz quanto à língua estrangeira e sua interação com falantes nativos.

O objeto teórico priorizado nesta pesquisa - replicação de estruturas para + infinitivo do alemão para o português - prevê que cada falante, durante seu processo de aquisição de L2, tenha combinado cada uma dessas estratégias na situação comunicativa. Em outras palavras, pressuponho que cada estrutura replicada tenha em sua base o exercício bastante complexo de estratégias metacognitivas, cognitivas e sócio-afetivas.

É importante salientar que, mesmo que a aprendizagem de uma língua estrangeira não seja feita de maneira formal, ou seja, em cursos especializados no ensino de línguas estrangeiras, as estratégias cognitivas utilizadas pelos aprendizes são 
sempre as mesmas, pois derivam de um processamento mental em busca de soluções típicas.

Tendo como base os conceitos teóricos de Oxford (1989 e 1990), as estratégias cognitivas estão subdivididas em quatro áreas:

1. estratégia de repetição;

2. estratégia de prática formal de associação de sons e sistemas ortográficos;

3. estratégia de reconhecimento e uso de fórmulas e modelos comuns às regras existentes no sistema da língua alvo;

4. estratégia de recombinação; e

5. estratégia de prática espontânea.

Estas duas últimas (estratégias 4 e 5) apresentam em comum a liberdade disponibilizada ao indivíduo no momento da produção de seu discurso, devido a características como construir uma sentença mais complexa unindo novas informações àquelas já conhecidas e consolidadas em sua mente, a partir da recombinação entre as informações "velhas" e informações "novas"; e a oportunidade de praticar suas habilidades linguísticas em uma conversa estabelecida com falantes nativos daquela língua.

A estratégia de prática espontânea, que consiste basicamente na recepção e envio de mensagens por meio da língua estrangeira, apresenta como alguns de seus recursos a inferência, transferência e generalização, fundamentais para o estudo de gramaticalização. 
A inferência é um processo mental através do qual o falante formula uma hipótese referente à língua estrangeira, baseado em evidências que lhe são apresentadas por meio do contexto vivenciado (relações entre os participantes do discurso e o tipo de assunto abordado, por exemplo). É também chamada de “estratégia interpretativa”. Assim, os falantes menos fluentes são mais dependentes de pistas linguísticas e de interação social de um determinado contexto.

A transferência refere-se ao processo de reaproveitamento de palavras, conceitos ou estruturas de uma língua para outra, com o objetivo de compreender ou produzir um discurso na língua estrangeira. No entanto, as regras que governam os atos de fala podem diferir substancialmente de uma língua para outra e, por isso, apresentar normas e regras distintas no que diz respeito à realização desses atos.

Por último, a generalização, que recobre ainda conceitos de analogia, regularização e supergeneralização, refere-se ao processo de estender algo conhecido a um contexto novo. No tocante aos atos de fala, a extensão ocorre em relação às regras que os governam.

Considerando que gramaticalização equivale a um processo de "exploração de velhas formas para novas funções” (WERNER \& KAPLAN, 1963 apud GONÇALVES, LiMA-HERNANDES e CASSEB-GALVÃO, 2007), que “conceitos concretos são mobilizados para o entendimento, explanação e descrição de um fenômeno menos concreto" (id.ib.), e que nesses processos são envolvidas a "transferência conceptual (metáfora), aproximando domínios cognitivos diferentes, motivação pragmática e reinterpretação induzido pelo contexto (metonímia)" (id.ib.), então fica evidente que os recursos inferência, transferência e generalização podem constituir gatilhos para o 
desencadeamento ou surgimento de elementos gramaticalizados $^{8}$ nos discursos proferidos em português por alemães nativos, no caso específico do interesse desta pesquisa.

Baseando-me nos conceitos de Hopper (1987) e de Traugott \& Heine (1991), Gonçalves, Lima-Hernandes e Casseb-Galvão (2007:15) postulam que

a gramática das línguas é constituída (...) de partes cujo estatuto vai sendo constantemente negociado na fala, não podendo em princípio ser separado das estratégias de construção do discurso e subjazem a esse entendimento uma concepção de língua como atividade no tempo real e a postulação de que, a rigor, não há gramática como produto acabado, mas sim constante gramaticalização.

e que esse mesmo termo, gramaticalização, "remete a um processo linguístico tanto diacrônico quanto sincrônico de organização categorial e de codificação” (id., p.23), ratifico a afirmação de que as estratégias de aprendizagem cognitivas podem, sim, funcionar como um gatilho eficiente para a replicação de itens em estágio de gramaticalização diverso nas duas línguas envolvidas (língua materna e L2). Então, se na gramática do alemão é possível encontrar a estrutura equivalente a para+infinitivo com funções altamente gramaticalizadas e inexistentes na L2 (português), também é possível que essa estrutura possa ser replicada nessa mesma L2 para outras funções. É esperado, contudo, que essa replicação seja avaliada como desvio (para o normativista) ou como uma estrutura normal de interlíngua (para o linguista).

A ocorrência de todos esses elementos descritos acima como estratégias de aprendizagem certamente resultarão no fenômeno da Interlíngua. Este caracteriza-se pela interferência da língua materna na L2 causando-lhe alterações perceptíveis na

\footnotetext{
${ }^{8}$ Nessa pesquisa, entende-se o termo "elemento gramaticalizado", a unidade linguística que sofreu o processo de gramaticalização.
} 
pronúncia, vocabulário, estruturação de frases e diferenças no âmbito idiomático e cultural. O efeito desse processo é a presença inevitável de formas da língua materna na fala do aprendiz:

O indivíduo que aprende uma segunda língua, além de ter que executar sequências de operações mentais (estruturar ideias) e de operações motoras (articular sons) novas, precisa também evitar os velhos hábitos da língua materna (HARPAZ, 2003).

Quanto mais constante a prática de uma língua, seja ela L1 ou L2, mais interiorizado e enraizado estará seu sistema linguístico. Por isso, quando um indivíduo resolve aprender uma língua estrangeira na fase adulta de sua vida, torna-se muito mais difícil de evitar as interferências de sua língua materna. Porém, mesmo para aprendizes adultos, o grau dessa interferência poderá variar de acordo com o modelo de performance ao qual estiver exposto bem como à intensidade de exposição à língua estrangeira.

Existem ainda pesquisas que demonstraram que alguns fatores fisiológicos interferem na aprendizagem de L2: o sistema fonador, por exemplo, se "enrijece" e se molda aos sons produzidos na L1. Os desvios linguísticos no uso da língua estrangeira podem se estagnar e, dessa forma, o aprendizado se fossiliza. É nesse estágio de fossilização da fluência em língua estrangeira que é detectada a replicação de processos de gramaticalização. 


\subsection{Relações entre aquisição de L2, pidgin e crioulo}

Antes de iniciar a apresentação do tema, deixo claro que, embora haja controvérsias quanto à origem dos termos pidgin e crioulo, o que acaba por se refletir em suas definições e desenvolvimentos, basear-me-ei nos argumentos de Bickerton (1984), Hall (1966), Honório do Couto (1996) e Tarallo \& Alkmin (1987), principalmente no que concerne aos conceitos gerais acerca do tema.

O pidgin, basicamente, “é uma língua auxiliar que surge quando falantes de diversas línguas mutuamente ininteligíveis entram em contato estreito" (COUTO, 1996), como é o caso do contato estabelecido pelos alemães que passam a viver em território brasileiro, mais especificamente na região de São Paulo, alvo de estudo deste trabalho.

Um dos pioneiros dos estudos crioulos e dos pidgins, Robert A. Hall Jr. (apud Couto, 1996) já explicara que o pidgin diferencia-se drasticamente do crioulo pela própria estruturação. Assim, a existência de um pidgin seria a condição necessária para o desenvolvimento de um crioulo: "pidgin não é uma língua nativa de nenhum de seus usuários", "é uma língua de emergência, de contato, drasticamente simplificada estruturalmente" e, consequentemente, "o crioulo resultaria sempre de uma complexificação estrutural e funcional do pidgin inicial". O crioulo, por sua vez, teria estatuto de língua nativa de uma comunidade. Com essa definição concorda a maioria dos pesquisadores do tema.

O pidgin, dado seu caráter totalmente instável, revela estratégias individualizadas para a comunicação interlinguística. Isso é possível porque não há normas socialmente reconhecidas, pelo simples fato de um grupo não conhecer a cultura e a língua do outro em sua totalidade, o que provoca o exercício do ensaio-erro na 
situação comunicativa. Essa também é, segundo o autor, a razão para que ocorram lexicalizações ou enunciados holofrásticos, circunlóquios, 'estruturação' pragmática, gramaticalizações por transferência ${ }^{9}$, além dos universais, segundo Mülhäusler (1984, apud CoUTO, 1996:27).

No estágio da estabilização há "uma eliminação gradual das soluções individuais e o estabelecimento de normas sociais. Ao mesmo tempo, tem-se o início de uma transição do modo pragmático de interação verbal para o modo sintático, como defende Mülhäuser (1986:125, apud CouTO, 1996:27). Note-se que o processo de mudança é similar, se não for exatamente o mesmo que ocorre em um dos estágios da gramaticalização que se baseia no conceito de Dik (1989, apud Lima-Hernandes, 2005:222): A expressão linguística, segundo o autor, é produzida em função da intenção do falante, de sua formação pragmática e da antecipação que faz da interpretação de seu destinatário. Dessa forma, o falante aprende L2, em situação de interação, preocupandose com a organização da informação, da interação e da organização semântica, e passa a produzir estruturas lexicogramaticais estranhas, mas que não coibem a comunicação pretendida. Lima-Hernandes (2005:224) ainda afirma que esses desvios são transformados em gramáticas provisórias que podem ser fossilizados em determinados padrões estáveis de uso.

Todas essas características apontadas, se transferidas para o objeto social de meu interesse nesta dissertação, permitem hipotetizar que um imigrante do alemão que não tenha domínio nenhum do português possa arriscar a se comunicar em uma língua do tipo pidginizante, mas essa língua não se desenvolverá em uma língua crioula, pois todos os alemães alvo desta pesquisa não se estabelecem tempo suficiente no Brasil para

\footnotetext{
${ }^{9}$ Grifo meu.
} 
que uma nova geração - mesclada geneticamente - se fizesse. Eles têm interesses profissionais com data já planejada de retorno ao país de origem.

O fato de se esforçarem para falar o português em vários níveis de fluência ou de interlínguas é que nos permite resgatar a história social do português de São Paulo, pois se, em situação de emergência comunicativa, há um alto índice de replicação de estruturas para + infinitivo, certamente houve fenômeno similar no passado, quando a colônia alemã, embora não tivesse o interesse de aqui permanecer, não tinha perspectiva de regresso, dado o contexto da guerra que assolava seu país. Portanto, diversamente seria o caso dos imigrantes que se instalaram no Brasil sem planos de regresso imediato e que aqui constituíram família e estabeleceram laços, ainda assim, ressalto que que nem todos os fenômenos de interlíngua podem ser tratados como casos de gramaticalização.

Ainda que sejam situações distintas de línguas em contato vivenciadas pelos dois grupos de alemães citados (os do iníco do século XX e os do século XXI, em São Paulo), em ambas estão implicadas fases de língua pidgin. Nesse sentido, Couto (1996:30) defende que "a linguagem dos estrangeiros também é um caso de situação pidginizante" e ilustra com exemplos da língua falada por alemães que residem ao sul do Brasil: Fech' die Janellen. Es chuvt, equivalendo a "Feche as janelas. Está chovendo". Apesar de serem lexemas alemães, a gramática é predominantemente da língua portuguesa. Casos como esses levam o autor a concluir que "sempre que povos ou indivíduos aloglotas entram em contato, pode ocorrer uma situação pidginizante, não, porém, um pidgin propriamente dito" (id.ib). 
Apesar de o português falado pelos "alemães paulistas" $" 10$ apresentar muitas das características dos processos de "pidginização" e "crioulização" apresentadas acima, existem critérios sociolinguísticos descritos em Couto (1996) que impediriam qualquer hipótese de língua crioula nesse contexto de uso:

- Critérios sociolinguísticos: 1 .Contato entre dois ou mais povos ${ }^{11}$ de línguas mutuamente ininteligíveis (situação de multilinguismo). Frequentemente um dos povos é superior socioeconômica e politicamente; 2. Não é língua materna de ninguém (língua de contato); 3. Meio precário de intercompreensão. (...); 4. No caso do pidgin, um modo de comunicação pragmático, ainda não há uma gramática comunitariamente aceita; 5. Os crioulos surgiram dos pidgins produzidos por povos aloglotas $^{12}$ que não se entendiam mutuamente, ou seja, surgem em comunidades bilíngues ou multilíngues.

De qualquer modo, esse processo pidginizante refletiria uma das etapas por que passa a língua produzida e aprendida em situação de contato direto, fora da escola. Esse é ponto em que se pode hipotetizar uma relação mais estreita entre etapa "pidginizante" e replicação, qual seja, somente após a fase pidginizante é que o falante estrangeiro, dada a intensa necessidade comunicativa no português, poderá efetivar transferências gramaticais ou replicar gramáticas.

Embora este estudo esteja, em grande parte, baseado nos conceitos descritos por Heine \& Kuteva (2006), abre um novo caminho de reflexão, pois não se refere ao contato entre línguas de povos geograficamente vizinhos, ou de povos que apresentaram no passado uma relação entre colonizado e colonizador, como faz o estudioso em suas análises. Tampouco se refere a comunidades fechadas estabelecidas em um território

\footnotetext{
${ }^{10}$ Os informantes alemães que se mudaram para São Paulo e vivem aí desde então.

${ }^{11}$ Grifo meu.

${ }^{12}$ Grifo meu.
} 
estrangeiro por motivos como a imigração em massa, sendo o caso de comunidades alemãs encontradas ao sul do nosso país, como aquela localizada na cidade de Pomerode, no Rio Grande do Sul, alvo de análise para várias pesquisas envolvendo contato entre línguas. Refere-se, sim, à análise do discurso em português proferido por alemães que vieram ao Brasil por diversos motivos, em épocas diferentes e que aqui se estabeleceram, sendo que a maioria desses informantes não apresenta vínculos entre si. Dessa forma, será possível investigar, ao menos apresentar indícios sobre o estatuto da replicação de itens em processos de gramaticalização: seria um processo que envolve membros de uma determinada comunidade "fechada"? aconteceria de forma semelhante em discursos de pessoas que tenham certas características em comum (são alemãs, cultas, de determinada classe social), mesmo que nunca tenham tido contato entre si, como um processo cognitivo, intrínseco a qualquer pessoa?

Portanto, as discussões tecidas durante esta seção parecem apontar para a necessidade de que eu adote uma estratégia preventiva: a composição de uma amostra de controle feita com os imigrantes estáveis habitantes da cidade São Paulo. Essa é uma necessidade que se consubstancia nas situações de contato e de aprendizagem da língua portuguesa aqui relatadas.

Analisando, no entanto, somente as ocorrências produzidas em português, não seria possível identificar indícios de um possível processo de replicação da L1 para a L2. Dessa forma, constituí nova amostra de controle a partir de língua escrita por alemães nativos, para que eu pudesse estabelecer uma comparação mais adequada.

Decidi por duas diferentes amostras para a comparação: a primeira delas é constituída pelas mesmas orações produzidas pelos informantes e transcritas por mim, porém, traduzidas para a língua alemã por um colaborador alemão nativo que não 
concedeu nenhuma entrevista. Essa amostra serviu para identificar se há uma correlação entre as ocorrências de para+infinitivo no português e no alemão. A segunda amostra é constituída por dados coletados de fóruns de discussão disponibilizados pelo jornal digital alemão Deutsch Welle e por dados coletados de um blog pertencente ao mesmo jornal, produzido por um jornalista e aventureiro a respeito de uma viagem que fazia à Antártida.

A justificativa para a escolha desses elementos se deve aos seguintes motivos: utilizar dados disponibilizados por um conhecido e repeitado jornal traz maior credibilidade ao uso corrente da língua alemã; os informantes "fantasmas" são (esperase) pessoas cultas; e há o fator espontaneidade, ou seja, a linguagem, ainda que obedeça à maioria das regras do padrão culto alemão, apresenta muitos elementos coloquiais, o que, como já foi citado anteriormente neste trabalho, é uma situação extremamente favorável ao emprego de usos inovadores. 


\section{Capítulo II}

\section{Revisão sobre o Tema}

Neste capítulo, trato de dois trabalhos que ecoam em vários outros trabalhos nas linhas da fundamentação teórica que escolhi para orientar este trabalho, quais sejam, contato entre línguas e gramaticalização. $\mathrm{Na}$ linha do contato entre línguas, o trabalho de Poplack tem peso tão significativo quanto o trabalho desenvolvido pela equipe de Bernd Heine, nos estudos sobre gramaticalização, daí a seleção dessas duas perspectivas para compor o quadro da revisão sobre o tema dos contatos linguísticos e gramaticalização.

\section{Gramaticalização e contato linguístico segundo Bernd Heine \& Hiroyuki Miyashita}

O trabalho de Bernd Heine, como orientador, como pesquisador e como parceiro de vários pesquisadores sêniores, tornou-se representativo e merecedor de citação primeira quando o tema é gramaticalização. Foi por meio desses trabalhos que a comunidade científica pode dar largos passos em direção à universalização de processos de gramaticalização, ao rompimento da dicotomização entre gramaticalização e lexicalização, e mais recentemente em direção ao estudo dos processos de gramaticalização e sua relação com a aquisição de línguas ou mesmo sua relação com o contato cultural entre povos.

Um trabalho que mais diretamente apresenta o método de trabalho no estudo da replicação e uma seleção mais direta de argumentos teóricos sobre a gramaticalização e 
o contato entre línguas é o artigo produzido em parceria com Miyashita (HEINE e MIYASHITA, 2009), que trata de um caso de replicação do francês no alemão, o uso do verbo ameaçar.

Os autores descrevem o processo como sendo “(...)um processo translinguístico regular diacrônico, cujos contornos principais podem ser descritos como condutores de uma estrutura como (1a) para uma estrutura (1b)" como segue:

(1) a gramaticalização de construções auxiliares (auxiliação)

a. um verbo principal (V1) - complemento do verbo não-finito (C)

b. $\quad$ auxiliar (A) - verbo principal (V2)

E explicam que com a palavra regular na definição de replicação remete à possibilidade de derivação das propriedades semânticas e morfossintáticas de (1b) num caminho baseado no de (1a).

O trabalho desenvolvido por Heine e Miyashita envolve o estudo de um grupo de quatro construções do Alto Alemão Moderno, todas envolvendo o item verbal drohen (ameaçar ). As quatro construções associadas com este item são ilustradas a seguir. Farei referência a elas como $\mathrm{C} 1, \mathrm{C} 2, \mathrm{C} 3$ e $\mathrm{C} 4$.

a) Karl droht seinem Chef, ihn zu verklagen. C1

Karl threatens to.his boss him to sue

'Karl threatens his boss to take him to court.'

(Karl ameaçou seu chefe de levá-lo à corte/ao juiz)

$\begin{array}{lllll}\text { b) Uns } & \text { droht } & \text { nun } & \text { eine } & \text { Katastrophe. } \\ \text { to.us } & \text { threatens } & \text { now } & \text { a } & \text { disaster }\end{array}$

'We are now threatened by a disaster.'

(Estamos agora ameaçados por um desastre) 
c)

$\begin{array}{llllll}\text { Das } & \text { Hochwasser } & \text { droht } & \text { die } & \text { Altstadtzu überschwemmen. C3 } \\ \text { the flood } & \text { threatens } & \text { the } & \text { old.town to flood }\end{array}$

'The flood risks flooding the old town.'

(A enchente ameaça inundar o centro velho).

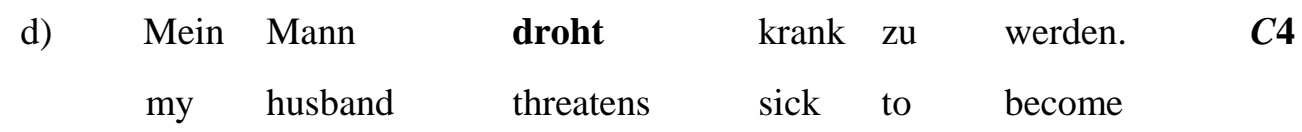

'My husband risks falling ill/threatens to fall ill.'

(Meu marido ameaça ficar doente)

Em C1 drohen é um verbo lexical pleno, que pode ser preenchido em seus três lugares, pois é, ao mesmo tempo, um verbo de atividade (ou a maneira) e um verbo de ato de fala. Possui uma casa destinada a um argumento agentivo que ocupará a posição de argumento externo (sujeito sintático) do caso nominativo. Em C2, não se tem mais o verbo de ato de fala, e o sujeito é não-humano numa construção passiva. O elemento humano ocupa uma posição de submissão a um evento fora de seu controle. Em C3 e em C4, há um verbo funcional que está em posição de $\mathrm{V} 1$, seguido do verbo principal na posição $\mathrm{V} 2$. Em $\mathrm{C} 4$, há ainda o fato de sinalizar o aspecto verbal, abrangendo o verbo de mudança de estado. São verbos que, a despeito de uma mesma forma e mesma origem, assumem padrões funcionais diversos.

O conjunto desses padrões poderia facilmente desenhar uma rota de gramaticalização de verbos no alemão, mas não é somente isso que está implicado nesses usos. Heine \& Miyashita demonstram em seu estudo que as diferentes construções de drohen no alemão não são únicas na Europa e podem ser encontradas em outras línguas européias, como o francês. Demonstram que os primeiros exemplos claros do verbo ameaçar funcional vieram de um desenvolvimento pertinente à língua francesa.

No francês antigo, o verbo menacer (ou menacier, manecier), que significa ' ameaçar ' era um verbo lexical formando uma construção C1, mas já por volta de 1.200 aparece a construção $\mathrm{C} 2$, trazendo um complemento introduzido pela preposição ablativa 'de', e significando que` algo constitui uma ameaça para alguém. A construção C3 foi estabelecida no 
francês antes de 1.300, demonstrada/evidenciada primeiramente já em 1200 (menacer de tomber: ameaçar cair). Mais tarde, na metade do século XVIII, o francês tinha desenvolvido uma construção C4, associada tipicamente com o infinitivo de tomber (verbo 'cair '), conforme o exemplo citado pelos autores e reproduzido a seguir:

(17) Et je l'ai crue menaée de tomber à mes pieds.

E eu acreditara que ela se arriscara a cair aos meus pés.

(E eu tinha acreditado que ela se arriscaria a cair aos meus pés $)^{13}$

Segundo Heine \& Miyashita (2009), foram necessários vários séculos antes que a gramaticalização do verbo ameaçar lexical sofresse mudança para funcional nas outras línguas europeias. No espanhol, por exemplo, os autores afirmam que $\mathrm{C} 1$ foi, até o século $\mathrm{XV}$, essencialmente a única construção disponível, mas que essa mudança se manifestou depois do francês no espanhol. Os primeiros casos atestados de 'amenazar' funcional datam do fim do século $\mathrm{XV}$, quando há casos tanto de $\mathrm{C} 2$, conforme exemplo (18), quanto de $\mathrm{C} 3$. A mais antiga confirmação de $\mathrm{C} 2$ com objeto nominal remonta ao exemplar encontrado em dicionário em 1492.

milagro que amenaza $\mathrm{mal}^{14}$

Segundo os autores, a evolução de ameaçar parece apontar para um marcador de infinitivo, seja com a presença das preposições de ou com, ou sem nenhuma preposição. Todos os exemplos anteriores a esse período que trazem o verbo 'amenazar' funcional envolvem complementos expressando a mudança de estado e é apenas no curso do século XIX que 'amenazar' passa a figurar numa construção $\mathrm{C} 4{ }^{15}$.

\footnotetext{
${ }^{13} 18^{\text {th }}$ century French (Prévost l'Abbé, Lettres angloises ou Histoire de miss Clarisse Harlove (trad.); p. $428 ; 1751$.

${ }^{14} 15$ th century Spanish (Antonio de Nebrija, 1492. Dictionarium latino-hispanicum. Salamanca; Cornillie 2005b)

${ }^{15}$ Os autores citam como fonte o trabalho de Cornillie (2004b: 362).
} 
Essas são as evidências para que os autores ratificassem sua hipótese de que o processo de gramaticalização em línguas germânicas parece ter sido deflagrado somente após o século XVI. Mais do que isso, os autores querem dizer que mesmo quando dois países não têm o contato vivo e direto entre pessoas, ainda assim pode ter tido algum tipo de contato diferente, como é o caso do contato cultural da França com países do mundo todo. Esse contato se daria sob variadas formas, que poderiam ter gerado uma replicação.

Se as intuições de Heine e Miyashita forem procedentes, como parecem ser, então é possível hipotetizar que uma construção de finalidade "para + infinitivo" em suas evoluções tão intensas, como demonstrou Sartin (2008), podem ter sido oriundas do contato com a língua alemã ou outras línguas européias que tenham funções mais gramaticalizadas do que a do português. Uma forma de dar início a essa reflexão é estudar os pontos frágeis de uma gramática de L1 e de L2 em contato, tal como proponho aqui.

\section{Contato linguístico segundo Shana Poplack: Code-switching}

Shana Poplack (1991) desenvolveu um estudo acerca de manifestações linguísticas resultantes do contato entre línguas numa perspectiva variacionista. Para um estudo dessa natureza, é imprescindível que os falantes utilizem regularmente duas línguas.

Dentre outros conceitos, o que mais chama a atenção nos estudos de Poplack (1991) para esta pesquisa é a descrição e análise do fenômeno descrito pela autora como code-switching, que é a combinação de sentenças, ou fragmentos de sentenças, pertencentes a dois sistemas gramaticais, ou subsistemas gramaticais em um mesmo ato de fala de falantes bilíngues. As regras gramaticais, diversamente do que se poderia supor, são preservadas em ambos os sistemas implicados. Assim, ocorre a troca de uma língua para outra durante uma interação comunicativa justapondo-se num mesmo 
período L1 e L2, e o resultado é uma estrutura sintática final mista e coerente. Essa troca é determinada pela função de cada língua no comportamento de cada indivíduo e pelo grau de competência em cada uma delas.

Um estudo dessa natureza também requer que se atente para as interrelações psicológicas e linguísticas do indivíduo, bem como com o grupo social em que está inserido. Portanto, muito mais do gramática e língua estão a serviço da realização do code-switching.

Aplicando esses requisitos de manifestação do code-switching à pesquisa que desenvolvo sobre o contato entre português e alemão, será necessário identificar no corpus sob análise dados que atendam aos traços do português padrão, do alemão padrão, de dialetos da língua alemã e do português coloquial, desde que não gerem incompreensões na situação interativa.

Muitos relatos da história social sobre a imigração alemã dão conta de que, em situações interativas, havia mescla de alemão e português, gerando uma língua estranha, mas totalmente compreensível, o que nos faz supor que o code-switching é típico de comunidades de imigrantes estáveis, sem perspectiva de regresso imediato à pátria. No corpus de língua falada de informantes que não pretendem permanecer por muito tempo em São Paulo, esse tipo de mescla não seria possível.

Uma aproximação entre a aquisição de L2 e as condições para surgimento de code-switching permite que se identifiquem os mesmos processos: físico, emocional, cultural e social. Deve, contudo, haver motivação para o aprendizado mais intenso da língua.

Em outra perspectiva de análise, aproximando o code-switching da gramaticalização no contato entre línguas, percebo que há uma certa semelhança entre os dois processos deflagradores. Enquanto o code-switching é, basica e literalmente, a 
alternância de sentenças, ou fragmentos de sentenças de diferentes línguas - estimulada por diversos fatores - na fala de um bilíngue, a gramaticalização no contato entre línguas apresenta-se como uma espécie de tradução dessas mesmas sentenças de L1 para L2, obedecendo-se a uma correspondência morfológica, fonética e/ou sintática com os elementos de L1, e encaixando-as em sentenças originais de L2 de modo que as alterações, ou adaptações ocorridas em L2 não sejam tão estranhas a ponto de tornar uma fala incoerente. Às vezes, trata-se de adaptações imperceptíveis ao próprio bilíngue. Portanto, de maneira geral, os dois processos baseiam-se em alternâncias, adaptações e substituições de sentenças (ou fragmentos de sentenças) de L1 em L2, ou vice-versa.

Como neste trabalho proponho um estudo a respeito da gramaticalização desencadeada por contato lingüístico entre o português falado por cidadãos alemães da cidade de São Paulo e sua língua materna, torna-se indispensável a reflexão acerca da história dos imigrantes alemães que há muito chegaram e contribuíram para a transformação social desse centro urbano.

A história social é relevante para compreender a história do contato entre pessoas, do contato entre línguas, dos preconceitos, dos estigmas e para compreender como uma comunidade receptora vê um imigrante e como julga sua fala "misturada". Além disso, é a única forma de reconstituir o que de fato ocorreu em São Paulo, com uma migração alemã sem perspectiva de regresso imediato à pátria. Para a maioria deles, sua pátria passou a ser o Brasil, dada a acolhida num momento de perseguição nazista.

O processo de imigração provoca profundas e significativas mudanças nas vidas dos seres humanos. Culturas, valores e línguas confrontam-se, disputam lugares e, por fim, podem misturar-se através da convivência. 
Os imigrantes falantes da língua alemã procediam de diferentes Estados germânicos e de setores muito diversificados da sociedade daquela época, Alemanha central, Prússia e Bavária. Dentre eles havia pequenos camponeses expropriados de suas terras e artesãos desempregados devido à industrialização (em sua maior parte). A partir de 1850, havia também engenheiros, médicos, profissionais liberais e comerciantes. Esses cidadãos alemães que se tornaram um peso para a moderna sociedade em formação na Europa, vieram contribuir significativamente para a sociedade paulistana que se apresentava num momento de transição da escravidão para o trabalho livre. Implantaram nas cidades que ocuparam uma diversificada gama de ofícios como oficinas, hotéis, farmácias, manufaturas de cerveja e de chapéus. Ajudaram, dessa forma, na evolução e no enriquecimento social e financeiro dos novos centros urbanos através do surgimento de novas classes médias.

Dentre tantas dificuldades, a que surge assim que os primeiros alemães chegam a São Paulo é a de estabelecer contato com os nativos brasileiros. Sem saber pronunciar nem mesmo uma única palavra, a maioria dos imigrantes sentiu um certo preconceito em relação à sua língua materna. Precisaram contar com a ajuda de um médico brasileiro que dominava a língua alemã para que pudessem reivindicar seus direitos como imigrantes previstos por lei assim que chegaram às terras paulistanas. No entanto, com o passar dos anos, os imigrantes alemães se adaptaram aos costumes locais, inclusive à língua, integrando-se completamente à sociedade. A aprendizagem da língua portuguesa deu-se, principalmente, através do contato com os cidadãos locais. Não havia escolas voltadas ao ensino da língua portuguesa aos imigrantes alemães.

No início da ocupação das regiões paulistanas pelos colonos alemães, seus modos mais arcaicos e conservadores, suas crenças religiosas e sua língua foram elementos que os tornaram pouco tolerados pelos cidadãos brasileiros locais, bem como 
pelas leis do Império. Seu sotaque denunciava sua procedência que, consequentemente, os identificava tornando-os alvos da rejeição. Muito pouco se sabe, no entanto, acerca do contato linguístico entre alemães e brasileiros, mas é possível resgatar indícios desse contato por meio da história cotidiana.

Nesse sentido, apresenta-se o próximo capítulo que visa descrever os aspectos mais relevantes da experiência de vida cotidiana dos alemães em São Paulo durante o século XIX para esta pesquisa. Uma rápida análise de um processo intenso de integração social desses imigrantes a ponto de se tornarem personagens principais da história do desenvolvimento e evolução da cidade de São Paulo como centro urbano e de uma reestruturação de valores e de costumes que perpassam os obstáculos e dificuldades geradas pelo distanciamento entre as línguas de origem (alemão) e a de seu novo lar (brasileira). 


\title{
Capítulo III
}

\section{Aspectos da História Social da Imigração Alemã: um olhar sobre São Paulo ${ }^{16}$}

\begin{abstract}
Este capítulo toma como objeto de discussão a imigração alemã e sua atuação social em São Paulo. Num primeiro momento analiso os aspectos históricosociais da imigração alemã para o Brasil desde a chegada dos primeiros imigrantes alemães no século XIX. Na seção 2, apresento um relato especificamente acerca da imigração alemã na cidade de São Paulo. Por último, desenvolvo uma análise dos aspectos linguísticos da língua alemã e de sua relação com a língua portuguesa.
\end{abstract}

Como ocorre em toda pesquisa científica, nesta tenho tomado o cuidado para não generalizar fenômenos que possam ser individuais e também não perder a proporção exata da criatividade individual para a resolução de um problema comunicativo bem pontual. Essa é a razão por que projetei a constituição de uma amostra de controle, gerada a partir de um grupo de imigrantes que guardam diferenças substanciais dos informantes prioritários desta pesquisa.

Para saber se o objeto teórico sob análise (replicação), observado mediante o a produção de dados contendo o objeto linguístico detalhado anteriormente (estrutura $v+$ para $+v$ inf) não seria uma tendência de uso prevista na fala de pessoas que tenham a mesma origem independentemente de ser imigrante que se estabeleceu no Brasil ou

\footnotetext{
${ }^{16} \mathrm{O}$ texto que deu origem a este capítulo é principalmente baseado em trabalho de Rezagli e Del Grossi (inédito) no ano de 2007.
} 
imigrante temporário, compus uma amostra a partir da produção de informantes estabelecidos no Brasil e, para compreender as situações de contato e de aprendizagem da língua, também realizei um estudo de caráter mais histórico-social que segue em detalhes.

Ao contrário do consenso de que a imigração alemã concentrou-se ao sul do Brasil, a configuração da paulicéia não se resume apenas a italianos e a japoneses. Uma parcela importante de alemães migrou para São Paulo. No Brasil, como um todo, essa parcela tem proporções variáveis.

\section{Aspectos histórico-sociais da imigração alemã para o Brasil}

Juntamente com os colonizadores portugueses o que se viu foi a vinda de alemães de maneira esporádica ao nosso país, até meados de 1808. Financiados e estimulados pelo governo português, os alemães desbravadores que aqui chegaram tinham como objetivo proteger e defender a terra.

Os germânicos eram, na maioria, profissionais que tinham um certo grau de cultura, ainda que grupos menos cultos também tenham feito parte do cenário, como revela Fouquet (1974: 19):

pertenciam às mais diversas profissões ou ofícios, integrando as mais variadas classes sociais: eram mercenários, comerciantes, militares, religiosos católicos, cientistas ou artistas. A serviço de Portugal, participavam da conquista, da defesa ou da exploração do território; tomavam parte ativa no plantio da cana-de-açúcar, no comércio, na catequização dos aborígenes e contribuíam para a formação política e social de uma população bastante heterogênea, espalhada por imensas 
matas e pampas, integrada por elementos de raças diversas, falando idiomas vários e observando costumes diferentes.

Em 1808, aconteceu a transferência do Príncipe Regente Dom João VI para o Rio de Janeiro. Nesse mesmo ano, o príncipe concedeu a abertura dos portos brasileiros às nações amigas e, em 25 de novembro, anexou ao documento um decreto que “possibilitou o acesso à propriedade fundiária a estrangeiros, incentivando a entrada de grupos imigrantes das mais variadas procedências no território brasileiro" (cf. SIRIANE, 2003).

O caráter das relações entre Alemanha e Brasil modificou-se com a instalação de Dom João VI e sua corte no Rio de Janeiro, em 1808, mas intensifica-se em 1817 com a chegada de D. Pedro I, acompanhado de sua mulher, a Grã-duquesa Leopoldina. Como afirma Dreher (2003: 29), “a maioria dos pesquisadores crê que a imigração germânica no Brasil se deve especialmente a uma sugestão da Imperatriz Leopoldina, filha do Imperador Francisco I da Áustria”. Essa ideia explica-se porque D. Leopoldina, como era chamada, assumia o poder sempre que D. Pedro se ausentava, participando ativamente das articulações de independência do Brasil. Apaixonada pelo país e muito respeitada por sua visão moderna e avançada (LYRA, 2001), a sua chegada fez com que os alemães, que em momentos anteriores aqui apareciam esporadicamente, começassem a afluir aos milhares:

A princípio os comerciantes e operários, em seguida os soldados e agricultores, começaram a vir em fluxos variáveis. A chegada da jovem princesa-noiva, que se deu em 1817, que em sua comitiva trouxe alguns homens de ciência e artistas que logo adquiriram renome no cenário mundial, assim como a fundação, em 1818, das primeiras colônias alemãs "Leopoldina" e "São Jorge de Ilhéus" são marcos desse movimento. De sua corte faziam parte oito cientistas e dois 
pintores, dando início às atividades científicas e artísticas no Brasil.(FOUQUET, 1974:24)

Ainda no que concerne aos motivos das primeiras imigrações, não se pode esquecer da perspectiva política de Portugal, que não tinha interesse em convidar imigrantes de nações possuidoras de colônias, como eram, na época, França, Espanha, Holanda e Inglaterra. Assim, abrir as portas da colônia ou do jovem Império a imigrantes dessas nações significava um risco enorme, preferindo o Brasil imigrantes da Alemanha, Suíça e Itália (cf. DREHER, 2003).

Também é importante ressaltar que a emigração em massa verificada na Alemanha no século XIX foi, em última análise, consequência dos desníveis sociais e econômicos existentes na região, tendo suas origens com o Bloqueio Continental, decretado por Napoleão Bonaparte, em Berlim, em 1806.

Inicialmente o bloqueio possibilitou um crescimento da indústria artesanal na área rural da Alemanha, mas, após as guerras de libertação e a consequente abertura dos mercados alemães, seguiu-se um progressivo empobrecimento das populações rurais. Para os estados alemães o período que engloba os anos de 1815 a 1848 foi marcado por grandes transformações econômicas e sociais devido ao processo de industrialização que acontecia de maneira lenta, porém gradual. Além disso, o artesão alemão não possuía especialização para trabalhar em indústrias e apresentava uma grande resistência à modernização, dois elementos problemáticos naquela sociedade.

O avanço industrial exercia, pois, pressões cada vez mais fortes sobre as pequenas oficinas artesanais. Paulatinamente muitos artesãos tinham sua força de trabalho substituída por máquinas modernas e, consequentemente, enfrentavam o 
desemprego e a ruína financeira (cf. SIRIANE, 2003). O primeiro setor econômico a industrializar-se foi o têxtil:

As dificuldades se acumulavam de acordo com os setores profissionais e a região. A crise na Alemanha atingiu principalmente o setor têxtil, que, mais do que qualquer outro, sofreu a concorrência da produção inglesa de tecidos, em rápida expansão. Os artesãos do pano sofriam dupla pressão: a de fora, vinda da Inglaterra (o estado Prussiano, por razões práticas, entre outras, para forçar a modernização do setor produtivo, não fechou suas fronteiras às importações) e a de dentro, com a introdução de máquinas que os substituíram no fabrico de tecido de lã, linho e algodão. A pressão interna, devido ao ritmo desigual de introdução da mecanização, não foi unifore. O setor de fiação foi o primeiro a mecanizar-se enquanto suas agregadas, as tecelagens, demoraram muito mais tempo a fazê-lo. (RENAUX, 1995:27, apud SIRIANE, 2003)

A melhor opção para esses artesãos era a emigração. Assim, grandes grupos partiam rumo às Américas do Sul e do Norte.

Em algumas regiões, fatores como a fome e as más colheitas fizeram com que os agricultores também emigrassem, já que as poucas indústrias existentes não tinham condições de absorver a mão-de-obra existente. Além desse fator, muitos alemães pretendiam fugir ao regime monárquico-reacionário da época da Restauração ou ainda escapar à carga tributária dos pequenos Estados (WILLEMS, 1980).

Segundo Siriane (2003), foi o decreto de D. João VI, em 16 de março de 1820, em que declarou o interesse do governo em receber alemães como imigrantes, o ponto de partida para a intensificação da vinda de alemães. O teor do decreto era o seguinte: 
Considerando a vontade de emigrar que os diferentes povos da Alemanha e de outros países manifestem pelo excesso de suas populações e considerando oportuno o estabelecimento de colônias estrangeiras no seu Reino do Brasil, seja para o bem deste mesmo reino, seja para o bem das famílias e pessoas que formarão as ditas colônias, Sua Fidelíssima Majestade Real se dignou determinar as condições sob as quais estes colonos deverão ser admitidos e as vantagens que lhe serão outorgadas.

$1^{\circ}$ - Sua Majestade concederá aos colonos estrangeiros vindos ao Brasil para estabelecer-se uma área gratuitamente para sua colonização. Esta área será de uma légua quadrada, mais ou menos, conforme a quantidade de famílias e pessoas que compõem a colônia.

\section{(...)}

$6^{\circ}$ - Os colonos que no Brasil se estabelecerem nas terras a eles cedidas gratuitamente deverão ser considerados, a partir deste momento, cidadãos de sua Majestade, sujeitos às leis e aos costumes do país; ao mesmo tempo, porém, desfrutarão de todos os privilégios e vantagens como os súditos portugueses.

$8^{\text {o- }}$ Para poder entrar no gozo dos mencionados direitos e privilégios, todos os colonos deverão ser de religião católica romana e pessoas de bons costumes e princípios. Deverão provar ambas as exigências mediante certificados que deverão ser reconhecidos pelos Ministros ou outros funcionários de Sua Majestade no exterior.

(Trechos do decreto de 16 de março de 1820)

O decreto mostrava, sem nenhuma inibição, que havia uma grande ansiedade em relação à vinda de europeus para o Brasil, mas em nenhum momento explicava o porquê. No entanto, Hipólito da Costa deixou bastante evidente em vários textos que 
escreveu para o Correio Mercantil que era a favor da introdução de brancos europeus no Brasil com o propósito de povoar o território e "melhorar a população".

Esse processo deveria ocorrer ao mesmo tempo em que ocorreria uma abolição gradual da escravidão no Brasil, pois, embora a mão-de-obra escrava fosse uma fonte muito lucrativa e atendesse com certo sucesso à demanda dos trabalhos nas lavouras, havia uma grande preocupação com o número de escravos, cerca de 1.500 .000 nas primeiras décadas do século XIX, no que diz respeito a possíveis rebeliões.

Essa situação criava um clima de grande tensão social. Hipólito da Costa completava seu discurso dizendo que "o assentamento de núcleos de imigrantes europeus também apresentava possíveis inovações nas técnicas de cultivo, que poderiam ser introduzidas pelos estrangeiros e imitadas pelos nativos" (SIRIANE, 2003).

Concomitantemente a essa época em que os pequenos estados germânicos passavam por dificuldades econômico-sociais, acontecia a Independência do Brasil em 1822, quando Portugal retirou as suas tropas do Rio de Janeiro, deixando a capital exposta.

Com a necessidade de uma nova defesa e aproveitando-se da empatia dos conterrâneos de sua esposa, D. Pedro I envia o major Georg Anton Aloys von Schaeffer às cortes alemãs. Com a finalidade de mover o maior número possível de pessoas para a imigração ao Brasil, Schaeffer e outros agentes faziam promessas que não eram aprovadas pelo governo brasileiro e que, em parte, contrastavam com a constituição brasileira (cf. DREHER, 2003). 
Os primeiros alemães aqui chegaram em 1824 e foram alocados no sul do Brasil, onde ocorriam sucessivas disputas territoriais. Eles provinham de diferentes regiões, já que no século XIX o termo alemão era utilizado para definir uma unidade de idioma e de cultura que abrangia diversos países, cada qual com particularidades regionais. Eram, segundo Fouquet, gente dos estados do Reich de 1871, incluída a Alsácia-Lorena, do Luxemburgo, da Suíça, da Áustria e Hungria, da Romênia, da Polônia e da Rússia e suas províncias bálticas, enfim, todos os países que haviam integrado a "Ordem alemã".

Apenas as autoridades os classificavam de acordo com a sua nacionalidade, ou de acordo com o Estado ao qual pertencia o lugar de nascimento naquela data, que deveria mudar com frequência ao longo do século XX. Assim, eram alemães aqueles imigrantes de língua alemã que aqui se radicavam (cf. FoUQUET, 1974).

Além de diferirem-se uns dos outros no tocante ao aspecto territorial, os germânicos apresentavam particularidades linguísticas, não sendo a língua alemã homogênea a todos. Foram introduzidos no Brasil quase todos os dialetos, entre eles o dialeto renano, chamado Hunsrückisch, ainda hoje existente no sul do Brasil em cidades como São Leopoldo, Igrejinha, Nova Petrópolis e Campo Bom; o Westfaliano, falado em Teutonia, Estrela e Lajeado; e o dialeto pomerano, falado na parte sul do Rio Grande do Sul, como em São Lourenço do Sul.

As principais atividades dos imigrantes, além do trabalho no campo, restringiam-se ao comércio em geral, ao artesanato e às indústrias. Alguns se tornaram livreiros, tipógrafos e oficiais de encadernação; outros se tornaram preceptores de línguas e ainda dedicaram-se à importação de produtos como perfumes, roupas e livros.

Após a primeira leva de imigrantes em 1824, D. Pedro I continuou o projeto de colonização de seu pai e, em 1828, incentivou a vinda de mais imigrantes através de 
intensa propaganda na Alemanha. Porém, a partir de 1830, a política migratória do Império sofreu grandes abalos. Pode-se citar a lei de 15 de dezembro de 1830, criada pelas forças conservadoras do parlamento aliadas aos latifundiários. Essa lei tirava do governo todos os meios financeiros para promover a colonização com estrangeiros no país.

Os latifundiários acreditavam que a política imigratória do governo visava à libertação dos escravos, e isso seria prejudicial para seus negócios. Contudo, essa medida do parlamento brasileiro não levou a uma interrupção total da imigração. Já em 1824, o governo conseguira, através de um ato adicional, que as diversas Províncias fomentassem a imigração por conta própria. Dessa forma, surgiram legislações que esclareciam a imigração, como a de 1854 (cf. DREHER, 2003).

Mesmo assim, as lacunas existiam. O estado prussiano resolveu, então, promulgar, a partir de 1853, leis que protegessem, por um lado, seus imigrantes e que, por outro lado, limitassem a emigração para o Brasil. A mais famosa dessas leis é o Rescrito de von der Heydt, promulgado em 1859, que deixava claro que não impedia a emigração para o Brasil, mas que visava a proteger seus súditos prussianos que pretendiam emigrar, mas poderiam ficar nas mãos de inescrupulosas de agentes (cf. DREHER, 2003). Ainda assim, o rescrito foi abolido em 1895, causando revolta na opinião pública brasileira, que acreditava ser essa medida uma tendência imperialista do Imperador alemão. Não se pode negar, contudo, o aspecto positivo da lei, já que forçou o governo brasileiro a regularizar a situação jurídico-legal dos protestantes.

Em 1889, proclamava-se a República no Brasil. Com esse fato surgiram para os descendentes dos imigrantes alemães duas vantagens significativas: a concessão generalizada de cidadania brasileira e a separação de Igreja e Estado, inovações estas 
que haviam sido exigidas desde o princípio pelos imigrantes. Porém, aconteceu o contrário, já que no Brasil a maioria dos descendentes dos imigrantes alemães ou integrava ou era simpatizante do Partido Liberal e defensora fiel da monarquia. Isso era evidenciado principalmente entre os protestantes.

Um segundo período de imigração alemã ocorreu no período entre guerras. Após a Primeira Grande Guerra Mundial, parte da burguesia, arruinada pela inflação e desemprego, emigrava para o Brasil. Porém, o desenrolar dos acontecimentos na Europa levou a que, no Brasil, fossem feitas demonstrações públicas em favor da Entente $^{17}$ as quais provocaram saques e levaram a excessos da população contra alemães e descendentes de alemães. O torpedeamento do navio brasileiro "Paraná", em 1917, levou ao rompimento das relações diplomáticas entre Brasil e Alemanha. As instruções proibiam a circulação de jornais em língua alemã e ordenavam o fechamento das escolas nas quais não era ministrado o ensino da língua portuguesa (cf. DREHER, 2003).

Um terceiro período de emigração foi visto após a segunda guerra mundial, mesmo com toda marginalização que esses germânicos sofriam. Dreher (2003:35) ainda explica que após a segunda guerra mundial, um grupo de suábios (pessoas que falavam o dialeto suábio, um dos dialetos da língua alemã) do Danúbio procurou o Brasil para aqui formar uma nova existência. Diferentemente do que presenciado até aquele momento, a emigração desses dois grupos foi motivada por questões religiosas e políticas.

Nos anos da Segunda Grande Guerra Mundial, medidas repressivas foram tomadas. Proibiu-se a publicação de jornais em língua alemã, o uso da língua alemã em lugares públicos; seguiu-se o confisco de livros e de documentos em casas de teuto-

\footnotetext{
${ }^{17}$ Segundo o Dicionário Houaiss eletrônico, entente refere-se a entendimento internacional; acordo que visa à troca harmônica de ações. (http://houaiss.uol.com.br).
} 
brasileiros; houve destruição de bibliotecas alemãs, confisco de armas das sociedades de atiradores, prisões e confinamentos. Mas ainda assim os imigrantes chegavam ao Brasil em busca de um novo lar e seus descendentes procuravam por uma identidade definitiva, uma tentativa de agrupamento da sociedade.

A falta de identificação com a cultura local foi um importante fator para o desenvolvimento do espírito associativo dos alemães, caracterizado pela criação de igrejas e escolas para a comunidade. Assim também aconteceu na cidade de São Paulo. Como a maioria dos imigrantes pertencia à religião protestante, foi necessária a criação de igrejas luteranas. Essas garantiam a identidade espiritual do grupo, além da cultural, já que as igrejas evangélicas defrontaram-se com o problema de conseguir preservar, tanto na doutrina como no idioma, uma unidade interna.

A esse respeito Dreher (2003:15) afirma que a manutenção de sua fé estava muitas vezes relacionada à manutenção das tradições de seus grupos étnicos e de sua língua. Dessa forma, entendemos o porquê de cultos e pregações serem feitos em língua alemã, de preferência por um pastor alemão, vindo da Alemanha especialmente para tal tarefa.

Contudo, a partir de 1939, também a igreja foi atingida em sua essência, quando novas leis eliminaram, progressivamente, todas as línguas estrangeiras do culto da comunidade. Os cultos, que até então haviam sido oficiados quase que exclusivamente em língua alemã, tiveram que ser oficiados em língua portuguesa, com a consequência de que a maior parte dos membros da comunidade não mais entendia a pregação feita em língua portuguesa. 
Também existiram as igrejas católicas, porém em menor número. A sua religião era a mesma do Estado (Brasil), por isso tiveram maiores assistências. Porém, ainda assim havia as mesmas dificuldades linguísticas.

\section{A imigração na cidade de São Paulo}

Os primeiros registros de imigração em São Paulo datam de novembro de 1827, quando vieram alemães que se fixaram na região de Santo Amaro e Itapecerica da Serra em decorrência de um aviso expedido pelo governo imperial ao Presidente dessa província. Nesse aviso era comunicado que um grupo de alemães estava sendo enviado e deveria ser estabelecido pelas autoridades (SIRIANE, 2003):

Sua Majestade o Imperador é servido que o vice-presidente da Província de São Paulo tome desde já as medidas que julgar convenientes para receber colonos estrangeiros que em breve sairão desta Corte para essa província, e os mais que sucessivamente lhe serão enviados a medida que forem chegando; recomendando-lhe que na distribuição das terras se escolham as mais salubres, não só porque assim o aconselha a humanidade, mas porque as vantagens que uns gozarem podem decidir outros a que venham procurá-las; e deixando ao seu discernimento fixá-los, se o julgar conveniente, na nova povoação dos campos do Guarapuava, ou em Vila Nova de Franca do Imperador, ou em qualquer outro lugar, que em Conselho eleger por mais vantajoso. E assim o manda pela Secretaria de Estado dos Negócios do Império participar ao mesmo Vice Presidente para sua execução, ficando na inteligência de que deve dar parte pela mesma secretaria da escolha dos lugares, e dos motivos que determinaram a preferência. Palácio do Rio de Janeiro, em 8 de novembro de 1827. Visconde de São Leopoldo. (DAESP, 
Livros de Registros de Avisos do Ministério do Império. Ordem: 7705, Livro I, Anos: 1821 - 1831).

O grupo, que era formado por duzentos e vinte e seis alemães, chegou após quarenta dias do aviso emitido pelo império. A província de São Paulo era um local com poucos recursos, com escassa infra-estrutura e pouco habitado, não estando, portanto, preparada para receber aquele grupo de estrangeiros. Por isso, num primeiro momento, foram enviados ao Hospital Militar de São Paulo, onde permaneceram por dois anos. A esse pequeno grupo foram juntando-se outros menos numerosos e formouse, assim, uma população de, aproximadamente, mil alemães.

Um dos principais obstáculos enfrentados por esses estrangeiros aqui no Brasil foi a questão da língua. Havia uma grande dificuldade de comunicação entre os estrangeiros e os nativos. Para tentar resolver tal problema, antes que o grupo se estabelecesse definitivamente na cidade, um médico paulistano chamado Dr. Justiniano de Mello Franco, que dominava o idioma alemão, foi tornando-se representante e autoridade máxima entre os imigrantes.

Enquanto os alemães aguardavam uma resposta definitiva a respeito das terras prometidas pelo governo, não conseguiam um trabalho e, por isso, não tinham renda fixa nem como se sustentar. Muitos acabavam vagando pelas ruas da cidade, entregando-se às bebidas e aos jogos.

O então diretor do grupo, Dr. Justiniano de Mello Franco, lutou por uma série de medidas que garantissem a sobrevivência do grupo. Uma de suas conquistas foi o estabelecimento de subsídios diários de \$ 160 réis para os adultos e $\$ 80$ réis para as crianças (cf. SIRIANE, 2003). 
Por conta do pagamento dos subsídios, funcionários locais deixavam de receber seus vencimentos, e essa situação fez nascer e crescer um sentimento xenofóbico em relação aos alemães. Entretanto, o governo logo tomou a decisão de entregar as terras do sertão de Santo Amaro a esses estrangeiros. Esse sertão era uma região com vegetação densa, de difícil acesso, além disso era abrigo para animais perigosos como suçuaranas e onças. A primeira reação dos alemães, ao chegar a essa região, foi de choque e frustração.

Mais tarde, soube-se através de uma portaria ministerial que não era do conhecimento do governo qualquer tipo de contrato entre os colonos e o governo imperial, por isso os colonos não tinham a obrigação de se manterem fixos naquelas terras que lhes foram destinadas; dessa forma, nenhum contrato formal prenderia os alemães ali. Então, poucos anos depois, muitos dirigiram-se à Vila de Santo Amaro e à cidade de São Paulo.

Entre os anos de 1827 e 1889, havia um quadro bastante diversificado no que diz respeito às profissões. $\mathrm{O}$ que predominava eram as profissões ligadas à agricultura. No entanto, muito alemães que se declararam agricultores quando da chegada ao Brasil não conheciam praticamente nada da profissão. $\mathrm{Na}$ verdade, eram sapateiros, alfaiates e pedreiros. Por isso um grupo de alemães que estava assentado na região do sertão de Santo Amaro abandonou suas terras e dirigiu-se à capital paulista. Lá, exerceram suas profissões de origem.

Em relação à distribuição geográfica dos alemães na região de Santo Amaro, pode-se constatar, a partir de informações contidas em inventários e em escrituras disponíveis no Arquivo do Estado de São Paulo, que viviam concentrados na região da vila. 
Santo Amaro torna-se auto-suficiente com um comércio relativamente agitado, pois estava numa área de rota de muitos viajantes. A região, durante todo o século XIX contribuiu para o abastecimento da cidade de São Paulo, principalmente no que diz respeito aos gêneros da agricultura, da madeira e da pedra de cantaria ${ }^{18}$. O crescimento de Santo Amaro, portanto, acompanhou o crescimento urbano da cidade de São Paulo.

Além da região da vila de Santo Amaro, os comerciantes e os prestadores de serviços alemães também apresentaram uma grande incidência demográfica, anos mais tarde, nas regiões da Sé e da Santa Ifigênia, pois ali concentravam-se as ruas mais movimentadas da cidade; no bairro da Liberdade, região que ligava a capital à vila de Santo Amaro e onde se estabeleceram comerciantes e artesãos; além das regiões do Brás e do Tatuapé, onde havia chácaras com pequenas lavouras de subsistência e alguns armazéns de secos e molhados.

A cidade de São Paulo concentrou o maior número urbano de pessoas de língua alemã que veio ao Brasil. Essa população chegou a ser maior do que aquela de Porto Alegre. A afluência, primeiro da Europa e posteriormente de outras partes de Brasil, desenvolveu-se por intermédio de levas de índole bastante diversas entre si na primeira parte do século passado, havendo aumentado após 1918, 1933 e novamente depois de 1945.

De início vieram os artífices e pequenos comerciantes. Em consequência foram sendo iniciadas fábricas e firmas comerciais, sendo que - terminada a Segunda Guerra Mundial - agruparam-se na região da Grande São Paulo diversas filiais da indústria alemã (cf. FOUQUET, 1974).

\footnotetext{
${ }^{18}$ Pedra de cantaria é utilizada na área de construção.
} 
A sociedade alemã, no Brasil, foi muito marcada pelo seu espírito associativo. Através de uma agressiva política de preservação de germanidade, iniciada desde o período da instauração da República, os alemães pretendiam fugir do processo de assimilação de sua cultura com a brasileira. Segundo Dreher (2003: 43), pretendia-se alcançar essa meta através de quatro caminhos: a imprensa alemã, a escola alemã, as congregações e as igrejas de fala teuta e a marinha alemã.

Dreher (2003:55) afirma que inicialmente os imigrantes tiveram que lutar pela mera sobrevivência. Seu isolamento na mata virgem praticamente não lhes dava a oportunidade de contato com a população brasileira nem a oportunidade de aprender sua língua. Os contatos isolados que, mesmo assim, foram estabelecidos praticamente não serviram para a integração, levando, no máximo, a que fossem adotadas determinadas particularidades linguísticas. Por isso deve ser visto como normal o fato de se continuar a usar a língua alemã no culto e na pregação.

Da mesma forma, pode-se entender o papel da escola. A educação no Brasil colônia não era preocupação dos portugueses, já que estes viajavam para a Europa quando necessitavam continuar seus estudos. O jovem império independente também não estava em condições de oferecer escolas às novas povoações. Contudo, para os alemães a escola deveria fazer parte da vida de todo jovem, já que essa era tradição em sua terra.

A solução para esse problema foi a criação de escolas alemãs, garantindo melhor inserção e manutenção dos códigos culturais e da ligação com o país de origem. Assim, a maioria das escolas particulares era mantida por associações para tal fim constituídas, algumas dependendo de outras sociedades, como as de auxílio mútuo, outras de responsabilidade de paróquias. 
Contemporaneamente às pequenas escolas rurais cresciam as escolas urbanas, com cursos de 5 a 7 anos de duração. A partir de 1900, surgiram escolas de duplo currículo, que tanto possuíam o sistema ginasial brasileiro como o curso médio das escolas alemãs. Os que concluíam o curso da "Escola Alemã” de São Paulo tinham, a partir de 1929, livre ingresso nas universidades alemãs - o que denotava o alto padrão daquele estabelecimento de ensino. Isso foi mantido até 1941.

A insuficiência do ensino de português em escolas particulares gerou censura e desconfiança. Até meados da década de 20, ainda havia inúmeras escolas rurais em que a língua portuguesa não era ensinada (isso acontecia porque os professores, nascidos no exterior, não dispunham de meios para estudá-la); também havia outras em que o ensino do vernáculo era precário, devido à falta de professores brasileiros para executá-lo, vez que estes preferiam permanecer nas cidades maiores.

É importante ressaltar que os alemães foram os primeiros estrangeiros a inserir o espaço escolar no território paulistano. Muitos foram os brasileiros de origem alemã que foram formados em cursos preparatórios, como professores bilíngues, culminando, após a Primeira Guerra Mundial, na criação da “Associação Nacional dos Professores Teutobrasileiros", sediada em São Paulo. Contudo, tanto esta como outras associações foram obrigadas a se dissolver após o desfecho da Segunda Guerra Mundial. Algumas das escolas foram adaptadas para o ensino ministrado exclusivamente em português, outras foram substituídas por escolas públicas provisórias ou simplesmente extintas.

Em 1864, foi fundada a "Sociedade Beneficente Alemã", ainda hoje muito ativa. Ponto culminante foi atingido entre os anos de 1919 e 1939. Havia nessa época, na cidade e nos subúrbios, quatorze escolas teuto-brasileiras, dentre as quais figurava o 
“Colégio Alemão de São Paulo", que possuía um ginásio em moldes brasileiros a par de um curso reconhecido na Alemanha.

Era pioneiro no gênero no país: mais de oitocentos jovens frequentavam-no, sendo que foi ele que deu origem ao "Colégio Visconde de Porto Seguro". Do mesmo período são a "Associação alemã para ciência e arte", o "arquivo da imigração alemã" e o "Instituto Hans Staden", que propiciou condições para a criação da "Fundação Martius", mais adiante, em 1951 (cf. FouQUET, 1974).

Juntamente com a escola e com a igreja, a imprensa alemã teve um importante papel na história da imigração, estando ativa em São Paulo desde 1878. Segundo Fouquet (1974:199), os jornais tinham um papel fundamental:

orientavam o leitor de maneira hábil e apropriada a respeito de acontecimentos da época, suscitando amor e compreensão em relação à nova pátria, à sua gente, ensinando-os a enfrentar problemas que lhes apresentava a natureza estranha e o clima a que ainda se não haviam habituado, incitando-os a cumprirem com suas obrigações e os esclarecendo a respeito de seus direitos. (...) Assuntos de agricultura, indústria, comércio, ciência, arte, religião ou literatura, também eram tratados. Ao lado de contos e romances de autores alemães, encontrava-se boa literatura brasileira. Mais tarde, em coluna própria, passaram os periódicos a se ocupar do imigrante e a dar a palavra a seus filhos e netos. Nunca se perdeu de vista as "colônias", sendo que essa imprensa logrou despertar-lhes o sentido de auto-consciência, por vezes até com certo exagero, em relação a colônias vizinhas.

A maioria dos empreendimentos jornalísticos tinha sua base em cooperativas até que algumas iniciativas particulares começaram a surgir. Algumas editoras cresceram 
como negócios de família, passando de pai para filho durante muitas gerações. Exemplos disso são a da família Troppmair, em São Paulo, com o "Deutsche Zeitung" (Jornal alemão) e seu sucessor, o "Deutsche Nachrichten" (Notícias alemãs). A principal renda dos editores era com assinaturas e publicidade, já que a venda avulsa era inexpressiva, a não ser nas grandes capitais.

Raros os jornais que tivessem compromissos políticos e talvez nenhum deles tivesse obtido lucro com a defesa de determinado partido, a não ser vantagens mediatas, como ocorria nos jornais vinculados às igrejas. Vários, todavia, recebiam subvenções das autoridades brasileiras, pelo que se apoiavam em suas atividades ligadas à colonização e ao recrutamento de imigrantes. Entre eles situava-se o "Deutsche Zeitung” por volta de 1907/1908. No mais, a imprensa teuto-brasileira era livre.

A fidelidade da imprensa teuto-brasileira ao Brasil era fato. Ainda que por vezes a natureza de suas intenções fosse posta em dúvida, engajou-se em defesa irrestrita pelos interesses do país, embora consciente de que a crítica fazia parte de sua função. A imprensa alemã no Brasil sofreu grandes restrições impostas no decorrer das duas grandes guerras mundiais, que lhe paralisaram as atividades durante diversos anos.

Com a proibição de 1940, a maioria dos jornais cerrou suas portas, sucumbindo a um destino não-merecido. Atualmente são publicados os semanários "Deutsche Zeitung", sucessor do diário "Deutsche Nachrichten" e o semanário "Brasil Post", em São Paulo. 


\section{O aspecto linguístico e a relação com a língua portuguesa}

O contato dos imigrantes falantes do alemão com o meio-ambiente, a sociedade e a cultura brasileiros resultou no processo de aculturação e consequente formação de uma "cultura híbrida" (WILLEMS, 1980), ou seja, uma terceira cultura que carrega a coexistência de atitudes e valores provenientes das duas culturas distintas das quais se originou (alemã e brasileira). Essa terceira cultura, a germano-brasileira, possui características evidentes e marcantes principalmente no âmbito linguístico.

Em solo brasileiro, os imigrantes alemães provenientes de diversas áreas da Europa (como Hunsrück, Vestfália e Pomerânea) e seus diferentes dialetos entram em contato. A grande maioria desses Mundarten (dialetos) possuem características muito específicas, a ponto de tornar o diálogo entre seus falantes impossível.

Por esse motivo, os diferentes grupos comunicam-se através do Hochdeutsch, a língua-mãe, ou seja, a língua alemã mais antiga e tradicional. Da mistura proveniente do contato entre os diversos dialetos, o Hochdeutsch e o português surge, principalmente ao sul do Brasil, a linguagem nomeada de teuto-brasileira. No entanto, devido à já citada diversificação dialetal entre os imigrantes, não existe uma língua teuto-brasileira unificada.

O constante processo de assimilação da língua nativa nessas comunidades incorporou mais de mil palavras brasileiras ao vernáculo dos imigrantes. Dessa forma, surgem palavras compostas em português e alemão, como Brasil Deutschtum, Deutschbrasilianertum, Schuhloja (loja de sapatos) e Milhebrot (pão de milho), numa mescla bem próxima ao que Poplack nomeia code-switching. Há palavras portuguesas que foram germanizadas como Carret (carreta), Larange (laranja), Scharak (jararaca), 
Rossa (roça), Fakong (facão) e Kamiong (caminhão), que não é uma mescla muito mais refinada e inominável. Houve, ainda, mudanças no que se refere às expressões idiomáticas, por exemplo, a expressão de cortesia do idioma brasileiro “Tudo bem?" foi traduzido literalmente para "Alles gut?" e assim utilizado pelos colonos. No entanto, a expressão "Alles gut" significa "tudo de bom" na cultura original alemã. Dessa forma, pode-se pensar numa estrutura sintática brasileira conformando o léxico alemão, que deve ser lido num contexto pragmático de cumprimentos brasileiros.

Observa-se também uma apropriação do português no uso dos verbos que ganham a terminação em alemão, surgindo, assim, lembrieren, namorieren, ofendieren e respondieren. Nesses casos, o morfema radical é brasileiro e o morfema flexional é alemão, ou seja, léxico brasileiro e gramática alemã.

Por último, também se podem assinalar interferências sintáticas como, por exemplo, no uso do verbo sonhar, "träumen": seu uso na língua tradicional alemã é feito em conjunto com a preposição "von", que em português significa "de”, ou seja, "sonhar de". Porém, passa-se a traduzir "sonhar com" literalmente, surgindo "träumen mit (com)" no linguajar teuto-brasileiro. Do ponto de vista da normatividade alemã, há um desvio claro. Do ponto de vista linguístico, temos um exemplo riquíssimo de que preposições regenciais podem ser incorporadas de uma língua em outra e estabilizar seu uso como correto numa comunidade fechada. Não é pidgin (tem uma estrutura gramatical desenvolvida), não é crioulo (não é produzido por falantes nativos), não é code-switching (não há mescla de léxico, tão somente de regência), não é interlíngua (não se está falando português ou uma L2). É uma língua corrente alemã, com interferências claras da língua corrente brasileira. 
Como consequência das interferências da língua portuguesa, a linguagem teutobrasileira torna-se bem peculiar, pois possui léxico, gramática, sintaxe e fonologia bem diferentes, distanciando seus falantes da sociedade nacional e até mesmo dos imigrantes recém-chegados. Por esse conflito inter-étnico, os imigrantes teuto-brasileiros sofreram grande preconceito linguístico e sua linguagem escrita era considerada de baixa qualidade, além de sua estética reprovada.

Há, no entanto, uma grande produção literária teuto-brasileira, chamada "literatura de almanaque e jornal", pois romances, obras de ficção e poesias eram publicadas por esses meios de comunicação escritos e editados por membros das próprias comunidades. A produção literária mais notória aconteceu em Santa Catarina, mais especificamente em Blumenau, cuja importância política evidenciou uma elite local empenhada em conservar traços culturais germânicos concomitantemente à valorização da cidadania e do território brasileiros.

Sua literatura refere-se ao novo ambiente, ao cotidiano nas colônias, aos percalços migratórios e às cidades e centros de civilização. Estes dois últimos elementos causavam certa estranheza antes da Primeira Guerra Mundial, quando já havia boa parte dessa literatura e eram poucos os centros considerados urbanos nas áreas coloniais. Acredita-se que a temática da cidade, mesmo que esta possuísse proporções aldeãs, tem relação com o sentido civilizatório atribuído à colonização alemã no Brasil.

Os alemães foram protagonistas do primeiro fluxo de imigração relevante no Brasil e tentaram, através da organização de uma estrutura comunitária com a construção de Igreja e Escola, a preservação e manutenção de seu patrimônio cultural e da língua alemã. No entanto, reconheciam a importância de se aprender o idioma local e a história do Brasil. 
Acreditavam que era possível manter sua cultura e costumes, conhecer a cultura e costumes locais sem que houvesse choques inter-étnicos entre eles. Lutavam para manter fora de suas relações familiares e com os outros membros da comunidade a língua e costumes nacionais. Reflete as ideias do Centro de Tradições Gaúchas de São Leopoldo a expressão que diz que as tradições "são a alma de um povo", e a perda das tradições significa a perda da identidade do povo.

Segundo Wilhelm Rotermund, teólogo e professor que fundou a "Livraria Evangélica", quando emigrou ao Brasil em 1874 e escreveu gramáticas para o aprendizado da língua alemã para os colonos aqui estabelecidos, a importância da língua alemã reflete a importância da cultura de um povo:

Não é outra coisa senão seu patrimônio cultural alemão, quer dizer, porque eles falam alemão, pensam em alemão, vivem como alemães e têm costumes e hábitos alemães, força e ideais alemães. Enquanto eles preservarem seu patrimônio cultural, eles desempenharão algo excelente, apesar do número reduzido deles. Mas se abrirem mão disto, então vai-lhes acontecer o que aconteceu com diferentes tribos germânicas [...] porque eles se adaptaram às línguas românicas e com isto adotaram as visões e o modo de vida dos romanos. No entanto, Claro que é recomendável [...] que todo alemão aprenda também a língua portuguesa nacional e oficial. Mas quem torná-la a língua da família e por isso adotá-la como língua materna para seus filhos, este está dando um passo muito determinado para o enfraquecimento da estirpe alemã na nossa pátria, o Brasil. Certamente nossos filhos devem conhecer nas escolas a língua e a história do país, mas devem, sobretudo, aprender a língua e a história da própria estirpe; e a história, o ensinamento e a doutrina de nossa religião cristã, que lhes devem ser transmitidos, só pode ocorrer em língua alemã. 
Fatores como o rompimento das barreiras de isolamento das colônias, ainda no século XIX, no entanto, favoreceram um contato mais sistemático com a sociedade nacional mais ampla. O processo de nacionalização durante o Estado Novo, quando houve a proibição do uso da língua alemã tanto na fala dos descendentes quanto na publicação de jornais, revistas, almanaques, em demais escritos, em cultos e em reuniões das sociedades germânicas, impulsionaram os fenômenos de assimilação e aculturação entre as culturas.

Tais fenômenos podem ser vistos como negativos para os descendentes germânicos, mas é certo que os imigrantes alemães contribuíram muito para a formação da nação brasileira. Até a chegada desses imigrantes, o país era composto praticamente por senhores e escravos, o que significa que foram eles que introduziram a classe social intermediária dos pequenos agricultores e, em torno deles, estabeleceram-se atividades complementares.

Como foi citado anteriormente, também foram os alemães responsáveis pelo crescimento e desenvolvimento de povoados rurais em cidades e implantação dos primórdios da indústria. Em relação à cultura na cidade de São Paulo, deram grandes contribuições nas ciências, artes, filosofia, literatura e nos dois setores que merecem maior destaque quanto à influência alemã, a escola e a religião.

E como citado anteriormente, a contribuição na área escolar foi grandiosa: numa época em que o governo brasileiro não tinha condições de proporcionar educação escolar aos imigrantes, estes lutaram para impedir o analfabetismo entre seus jovens organizando escolas primárias comunitárias que mais tarde tornaram-se escolas públicas e particulares oferecidas a todos, independentemente das origens. É por todos esses 
componentes que Fouquet afirma que São Paulo deve ser reconhecido como o centro gravitacional da cultura brasileiro-alemã. 


\title{
Capítulo IV
}

\section{Replicação da estrutura $v+p a r a+v$ infinitivo no português $L 2$}

\begin{abstract}
Neste capítulo apresentarei as regras regidas pela norma culta alemã a respeito do emprego dos verbos em sua forma infinitiva e a estrutura utilizada em orações subordinadas finais, $u m \ldots z u$, baseadas nos conceitos apresentados por Monika Reimann em sua gramática Grundstufen Grammatik für Deutsch als Fremdsprache e por Herbert Andreas Welker em seu livro Gramática Alemã. Em seguida, baseada nos estudos de Elisângela Sartin (2008), Gramaticalização de combinação de orações: estruturas "para + infinitivo" no português, resgatarei o que a autora estudou sobre a gramaticalização das orações para + infinitivo, em português, e depois voltarei a atenção às produções de meus informantes para proceder ao estudo contrastivo. É exatamente essa análise que me permitirá avaliar a hipótese sobre a replicação do processo de gramaticalização do alemão ao português falado por alemães radicados no Brasil.
\end{abstract}

\section{O emprego do infinitivo na língua alemã}

Na língua alemã, existem dois tipos de infinitivo: o infinitivo simples e o infinitivo com $z u$ (Welker, 2008 ). Somente o primeiro é utilizado no português, mas os falantes de português L2 adotam indistintamente as duas estruturas para se comunicar 
em português. A seguir descrevo os usos normativos do alemão para, na sequência, demonstrar as replicações para o português.

\section{a) $O$ infinitivo simples}

Chamado somente de "infinitivo", o infinitivo simples é construído sem auxílio de preposição e ocorre nas seguintes situações específicas.

- no futuro do presente, formado pelo verbo auxiliar werden + verbo principal no infinitivo e no Konjunktiv com o verbo auxiliar würden:

(19) Wir werden dich benachrichtigen. (Nós te avisaremos.)

(20) Er sagte, er werde bleiben. (Ele disse que ficaria.)

(21) Ich würde das nicht tun. (Eu não faria isto.)

- como complemento dos verbos modais, dos verbos de percepção sehen (ver), hören (ouvir), riechen (cheirar), fühlen(sentir), spüren (sentir) ou dos verbos bleiben (ficar), fahren (ir utilizando-se algum meio de transporte), gehen (ir), heissen (chamar), helfen (ajudar), kommen (vir), lassen (deixar), lehren (ensinar), lernen (aprender), schicken (mandar, enviar):

(22) Wir müssen viel lernen. (Temos que estudar muito.)

(23) Siehst du ihn kommen? (Você está vendo ele vindo?) 
(24) Ich fahre Tennis spielen. (Eu vou jogar tênis./ Estou indo - de carro, bicicleta, etc. - jogar tênis)

- como sujeito da oração - e nesse caso é escrito com letra maiúscula, pois teria o valor de um substantivo:

(25) Warten ist furchtbar. (Esperar é horrível.)

(26) Hier ist Rauchen verboten. (Aqui é proibido fumar.)

- como o predicativo do sujeito ou do objeto:

(27) Nicht immer heisst arm sein auch leiden. (Nem sempre ser pobre significa também sofrer.)

- no lugar do imperativo:

(28) Aufstehen! (Levantar!)

(29) Bitte noch nicht shreiben. (Favor não escrever ainda.)

- como partícula separável de alguns verbos como bleibenlassen (parar com, deixar), kennenlernen (conhecer), seinlassen (deixar, não fazer), etc:

(30) Wir haben uns gestern kennen gelernt. (Nós nos conhecemos ontem.) 
(31) Lass das sein! (Deixe isso!)

- com valor locucional equivalente a estar + gerúndio, em algumas regiões alemãs, em letra maiúscula junto com o verbo sein $+a m$ :

(32) Er ist am Arbeiten. (Ele está trabalhando.)

(33) Diese Tiere sind am Aussterben. (Estes animais estão em via de extinção.)

Portanto, sete são as possibilidades de emprego do infinitivo simples no alemão. Existem, contudo, casos em que o infinitivo vem combinado a outras partículas. Esses são os casos de construções infinitivas complexas que apresento na sequência desta seção.

\section{b) $\mathbf{O}$ infinitivo com $z u$}

A preposição $z u$ deve acompanhar o infinitivo em alguns casos específicos, sem que ela apresente significado algum nesse tipo de locução.

O infinitivo com $z u$ pode ocorrer sozinho ou pode ser acompanhado de outros elementos, sendo chamado de "infinitivo ampliado". Nos dois casos, ele é considerado oração reduzida de infinitivo. É empregado nos seguintes casos: 
- quando constituir uma oração subordinada substantiva objetiva:

(34) Ich hoffe, dich nie wieder zu sehen. ( Espero nunca mais te ver.)

- quando no caso de verbos não citados no item "infinitivo simples":

(35) Er befahl den Soldaten zu schiessen. (Ele ordenou aos soldados atirarem.)

- quando o infinitivo ou toda a oração infinitiva exercer a função de complemento nominal:

(36) Ich bin sicher, dir schon morgen eine Antwort geben zu können. (Estou certo de poder dar-lhe uma resposta já amanhã.)

- quando ele é o sujeito da sentença:

(37) Viel zu essen ist nicht gut. (Comer muito não é bom.)

(38) Es geffält mir jetzt nicht mehr, per Anhalter zu fahren. (Agora não me agrada mais viajar de carona.)

- quando ele é o predicativo do sujeito:

(39) Mein Taum ist, auf einer Insel zu wohnen. (Meu sonho é morar numa ilha.) 
- quando é complemento dos verbos brauchen (precisar), drohen (ameaçar), haben (ter), pflegen (costumar), scheinen (parecer), sein (poder ser, dever ser), vermögen (ser capaz) e versprechen (prometer) - nesses casos ele faz parte do "complexo verbal":

(40) Du brauchst nicht zu kommen. (Você não precisava vir.)

(41) Das Haus droht einzustürzen. (A casa ameaça cair.)

- quando a oração infinitiva é introduzida pelas conjunções anstatt, statt (em vez de), ohne (sem) ou um (a fim de, para), as quais são as únicas que permitem o emprego de orações infinitivas:

(42) Ich arbeite nicht nur, um Geld zu verdienen. (Eu não trabalho somente para ganhar dinheiro.)

Existem, ainda, outros casos complexos que exigem uma combinação de elementos que não se encontram justapostos nas orações. São os casos apresentados na seção seguinte.

\section{b.1) $u m$... zu: a estrutura para + infinitivo em alemão}

Ao contrário do que ocorre em português com "em vez de", as conjunções alemãs (an)statt (em vez de), ohne (sem), um (para, a fim de) só podem formular orações que apresentem o sujeito - implícito e idêntico ao sujeito da oração principal. Caso contrário, no lugar de um a conjunção damit é que deve ser usada. 
(43) Wir rannten, um den Bus nicht zu verpassen. (Nós corremos para não perder o ônibus.)

(44) Ich habe dir das Geld gegeben, damit du Zigaretten kaufst. (Eu lhe dei o dinheiro para (você) comprar cigarros.)

Os exemplos deixam clara a exigência de marcação de diferenças sintáticosemânticas de sujeitos. Em português, essa marcação não é explícita e, por isso, não é percebida pelos usuários da língua, por isso somente linguistas em um trabalho descritivo conseguem formalizar essas diferenças, que acabam se configurando na língua do dia-a-dia como uma variação estável.

\section{c) A preposição um:}

Em relação à locução conjuntiva $u m . . . z u$, é formada por duas preposições: $u m$ e $z u$. A preposição $u m$ é a responsável pela ideia de finalidade na oração subordinada final, pois na dupla $u m \ldots z u$, segundo Reimann, em sua gramática Grundstufen Grammatik für Deutsch als Fremdsprache, é ela a que indica a ideia "a fim de".

No entanto, como uma preposição, pode ser utilizada em outros contextos, isoladamente da preposição zu. Nesses casos, pode indicar a ideia de "à volta de", "por volta de" (exemplos 45 e 46) ou indicar uma ideia temporal (exemplos 47 e 48). Por exemplo:

(45) Gehen Sie um den Häuserblock. ${ }^{19}$

Dê (o senhor/a) a volta na quadra.

\footnotetext{
${ }^{19}$ in Welker, 2008, p.214.
} 
(46) Die Kinder

$$
\text { sitzen }
$$

$u m$

den Weinachtsbaum ${ }^{20}$.

As crianças (estão) sentadas

em volta da árvore de Natal.

(47)

$\begin{array}{llll}\text { Der Zug } & \text { Kommt } & \text { um } & 15.34 \mathrm{Uhr} \text { an. } \\ \text { O trem } & \text { chega } & \text { às } & 15.34 \mathrm{~h} .\end{array}$

(48) J.W. von Goethe ist so um 1750 geboren ${ }^{22}$.

J. W. von Goethe em 1750. (morreu)

Como se pode perceber dessa exposição sucinta, os empregos da expressão v + para $+\mathrm{v}$ (infinitivo) no alemão possui nuanças de sentido e de conformação sintática diferente daquela que utilizamos no português padrão. A esse respeito, encontramos o estudo de Sartin (2008), que descreveu os padrões funcionais dessa estrutura e os valores a elas correlacionados, o que demonstra que não é tão simples assim o emprego dessa estrutura também no português corrente.

\section{A estrutura $v+p a r a+v$ infinitivo na língua portuguesa}

Nas gramáticas normativas consultadas para a execução deste trabalho, Cegalla (2005), Cipro Neto e Infante (1997) e Cunha \& Cintra (1985), e consequentemente, nos livros didáticos de Cereja e Magalhães (2004) e Paschoalin e Spadoto (1996), as orações reduzidas de infinitivo encabeçadas por preposição na configuração $v$ (fin) + para $+v$ (inf) são descritas como codificadoras de finalidade. Por essa razão, são categorizadas no conjunto das orações subordinadas adverbiais finais.

\footnotetext{
${ }^{20}$ in Reimann, 2005, p. 165.

${ }^{21}$ id., ib. Com relação ao elemento an, ao final da oração, é um prefixo que faz parte da estrutura do verbo principal, ankommen que é um verbo separável (Trennbar Verb), ou seja, o verbo é conjugado sem a presença do prefixo e se mantém em sua posição $\left(2^{\mathrm{a}}\right)$ na oração, ao final desta o prefixo é citado complementando o sentido total do verbo.

${ }^{22}$ id. ib. A locução verbal ist...geboren indica o pretérito perfeito "morreu".
} 
Ao tratarem de orações de finalidade, muitos gramáticos (e livros didáticos), dentre os quais estão Cegalla (2005), Cipro Neto e Infante (1997), Cunha \& Cintra (1985), Cereja e Magalhães (2004) e Paschoalin e Spadoto (1996), indicam que o uso prototípico é aquele encabeçado por para $+q u e+v($ fin $)$. Essa indicação, contudo, não coincide com a realidade dos usos, majoritariamente representada pela formalização para $+v($ infin $)$.

Bechara (1999), numa análise mais detida, constroi um raciocínio interessante sobre a diferença entre as infinitivas flexionadas ou não-flexionadas. Segundo ele, além da interpretação comum de que indica intenção, objetivo, finalidade do pensamento expresso na oração principal, afirma que podem codificar outros valores em contextos específicos.

O infinitivo sem flexão, segundo o autor, revela que a nossa atenção se volta especialmente para a ação verbal; a flexão, ao contrário, serviria como recurso de insistência da pessoa do sujeito. Ilustra com os seguintes exemplos:

(51) Estudamos para vencer na vida (para vencermos na vida).

(52) As crianças são acalentadas para dormirem, e os homens enganados para sossegarem (Marquês de Maricá)

Sobre a estrutura para + infinitivo, Bechara (1999) demonstra a função de um emprego específico, qual seja, pedir para, que indica uma nova acepção semântica do uso de estruturas para+infinitivo. $\mathrm{O}$ autor explica que o verbo pedir precisa de um objeto direto (uma "coisa") e de um objeto indireto (a/para "alguém") como complementos, ou seja, Pedir a alguém (objeto indireto) um favor (objeto direto). 
Segundo o autor, se o objeto direto é um favor, então após o verbo pedir pode-se acrescentar uma oração subordinada adverbial final que indique qual é o objetivo do favor. Exemplo: Pediu-lhe licença para sair (ou para que saísse). Neste caso, deve-se entender que o sujeito do verbo pedir é o mesmo do verbo da oração subordinada adverbial.

Segundo o autor, essa ocorrência surge da aproximação das ideias pedir que algo aconteça (oração subordinada substantiva objetiva direta) e trabalhar para que algo aconteça (oração subordinada adverbial final), por conta da linguagem coloquial. Dessa forma, a preposição para é utilizada para iniciar a oração que serviria como objeto direto do verbo pedir.

Neves (2002) expõe, em sua gramática descritiva do português, que as orações finais iniciadas por preposição para levam o verbo para o infinitivo e não apresentam restrição quanto ao sujeito. Há períodos cujas orações finais compartilham o mesmo sujeito. Nesse caso, o infinitivo pode ou não estar flexionado, mas a maior incidência de flexão reflete os casos em que os sujeitos detêm traço [-identidade], ou seja, não são idênticos. Observem-se os exemplos seguintes:

(49) As autoridades se organizaram para regularizar o abastecimento do leite. (PASCHOALIN \& SPADOTO, 1996)

(50) As crianças são acalentadas por dormirem, e os homens enganados para sossegarem. (Marquês de Marica, apud BECHARA, 1999)

Segundo a autora, em vários contextos exemplificados, a relação de finalidade com a oração principal parece estar expressa a partir de um núcleo nominal, o que torna 
opaco esse valor típico de finalidade. Entretanto, se a estrutura para+infinitivo indicar finalidade, a oração principal apresentará um sujeito capaz de exercer controle sobre o evento expresso na oração final, tal como se pode observar no exemplo seguinte:

(53) Esboçou um movimento para seguir em frente.

Neves ainda faz uma análise das orações finais, dividindo-as em dois tipos:

1. as que se ligam ao conteúdo proposicional da oração principal (adverbiais circunstanciais), como no exemplo (53); e

2. as que modificam o próprio ato linguístico (adverbiais de enunciação), como no exemplo (54).

(54) Para dizer a verdade, não sei o que se passa na cabeça do rei.

As orações finais em infinitivo iniciadas por preposição não apresentam restrição quanto ao sujeito, afirma Neves. Há orações com o mesmo sujeito da principal, podendo ou não ter o infinitivo flexionado para concordar com o sujeito. Há, também, combinação de orações com sujeitos com [-identidade] e, nesse caso, o mais comum é que o infinitivo apareça flexionado para concordar com o sujeito.

Existem casos, ainda segundo Neves, em que a oração iniciada pela estrutura para+infinitivo está ligada a um núcleo nominal apresentado na oração principal. Nesse caso, a oração caracteriza-se como uma oração subordinada substantiva completiva 
nominal, conforme o exemplo (55). Nesse caso, há a tendência de que os sujeitos das orações envolvidas sejam correferenciais.

(55) O entrevero com Maria Mimosa lhe dera tempo para recuperar a sua famosa calma nos momentos de ação. (Neves, 2000)

Numa abordagem funcionalista do processo de gramaticalização da combinação de orações, Sartin (2008) demonstra que, pelo menos desde o período antigo até o século XVI, ocorre uma "inovação" quanto à utilização da estrutura para +infinitivo. Segundo a autora, a ideia que fazem Mattos e Silva (1989), Said Ali (1964) e Epiphânio Dias (1970) sobre a motivação para o emprego da estrutura que não fazia parte do padrão culto da língua é a necessidade de argumentos sintáticos e de se colocar em evidência um novo sujeito.

Refletindo sobre o tema, Sartin argumenta que, tendo em vista que o português deriva do latim vulgar, é plausível supor que a inovação semântica tenha se implementado de modo bem tênue, mantendo a estrutura original. Se, recolhendo dados divergentes no português atual, podem-se ter pistas das várias fases de uso no português falado de outras épocas, então faria sentido pensar que esse processo de deslizamento hoje percebido esteja já há muito tempo se processando no português falado. E ainda, dado que as fronteiras entre fala e escrita tem sido cada vez menores, também faz sentido supor que muito do que é falado esteja sendo registrado em sua modalidade escrita.

A partir de seus estudos, Sartin conclui que mesmo sendo as orações [-finitas] pouco recorrentes nas gramáticas, por exemplo a gramática dos autores Cunha \& Cintra 
(1985), também consultada para o presente estudo, (e em materiais que os tomam como modelos), nem sempre é percebida alguma diferença entre as duas formas de codificação e entre as várias funções da oração para + infinitivo.

Construída sua posição calcada na descrição de usos, Sartin (2008) propõe oito critérios fundamentais para discernir entre os padrões funcionais da estrutura para + infinitivo no português, sendo um deles de caráter social ou externo. Trata-se do sexo do informante $^{23}$. Os demais são de caráter estritamente linguístico, quais sejam: estrutura formal, presença do sujeito, semântica do verbo, polaridade, valor semântico e material interveniente:

a) Estrutura formal - a autora identificou as estruturas formais: para + verbo, $0+$ verbo e para + material interveniente + verbo.

b) Material interveniente - nos dados colecionados por Sartin, a autora identificou três tipos de materiais nesse contexto: pronome, sintagma nominal e advérbio.

c) Valor semântico: as orações formam um conjunto em que todos os elementos constituintes apresentam o valor semântico de finalidade, no entanto tal valor não aparece sempre explicitado pela estrutura para + infinitivo. Sartin identificou cinco nuanças semânticas: finais exclusivamente (indicam o objetivo), desbotadas semanticamente (acumulam tanto a função de argumento sintático quanto a de finalidade já enfraquecido), encaixadas (orações altamente entrelaçadas que

\footnotetext{
${ }^{23} \mathrm{O}$ estudo de Sartin compõe um rol de informantes bastante interessante: professores de duas escolas públicas, que serão consultados por meio de testes, e produções dos alunos desses professores. Sua intenção é mostrar que existe uma ideia incutida pela normatividade que é regra categórica a função de finalidade nessa construção sob análise. Que o professor ensina com base nessa regra aprendida e não abre espaço para discussão com seus alunos. As meninas e os meninos são avaliados quanto à aderência dessa normatividade, daí a variável sexo.
} 
desempenham função de complemento), ambíguas (acumulam função de finalidade e outras circunstâncias) e discursivas (sinalizam informações ligadas ao plano das intenções).

d) Polaridade: quando uma oração subordinada apresenta o valor semântico de finalidade, segundo Sartin, espera-se uma polaridade positiva. Ou seja, já que a ideia de finalidade transmite a possibilidade e o desejo de se alcançar um objetivo, espera-se que este seja de fato conquistado. Por isso, uma polaridade negativa teria a capacidade de alterar o valor semântico original dessas orações, porém ela não é somente aprendida em orações negativas, mas ainda em orações afirmativas com itens de polaridade negativa (com marcação não-explícita).

e) Semântica do verbo: Sartin identificou diferenças de usos ao discernir os verbos que aparecem na estrutura para+infinitivo segundo codificassem ação física, ação mental, estado, movimento, dicendi, perceptivo modal e processo.

f) identidade entre sujeitos: correferencialidade dos sujeitos e não-correferencialidade dos sujeitos.

Esses critérios serão empregados para avaliar as estruturas para + infinitivo produzidas pelos alemães falantes de L2. 


\section{A estrutura $v+$ para $+v$ (infinitivo) no discurso de alemães sediados em São Paulo}

Muitos estudos acerca do contato entre línguas têm sido publicados em livros e monografias. Vários fenômenos resultantes desse contato têm sido observados e analisados por diversos pesquisadores.

As pesquisas baseiam-se, geralmente, no estudo de povos geograficamente vizinhos, o que facilita, obviamente, o contato entre suas línguas maternas. Ou ainda, comunidades de imigrantes que se formam em países que os acolheram, como é o caso do Brasil, onde encontramos colônias alemãs, geralmente, ao sul e colônias italianas no sudeste, por exemplo. Trata-se de comunidades bilíngues que fazem questão de manter aspectos da cultura tradicional de sua terra natal, incluindo sua língua.

A proposta deste estudo diferencia-se da maioria daqueles mencionados acima, pois não está baseado na análise do produto resultante do contato de línguas entre povos geograficamente vizinhos nem de indivíduos pertencentes a uma determinada comunidade bilíngue.

O estudo baseia-se em alemães que fixaram residência no Brasil, porém que não dominam com alto grau de fluência a língua portuguesa, que é para eles L2. Todos os informantes entrevistados são cidadãos comuns, residentes na cidade de São Paulo e não necessariamente pertencentes a comunidades bilíngues, a não ser sua própria família. Mesmo que alguns dos informantes pertençam a grupos como clubes e igrejas, cujos frequentadores em grande parte apresentam-se como bilíngues, cada um deles é 
participante de instituições diferentes, ou seja, os entrevistados não pertencem todos a um mesmo grupo de convívio.

O objetivo deste estudo não é estabelecer um padrão linguístico comportamental de um grupo isolado, mas analisar se, mesmo vindos de diferentes regiões da Alemanha, e mesmo sem estabelecer contato entre si, haveria um fenômeno que indique um processo de gramaticalização que se replica na fala em situação de comunicação em português L2.

Para a produção desta análise, muito do que se refere a pesquisas a respeito do contato entre línguas foi estudado e, por coerência à hipótese levantada para o desenvolvimento do trabalho, os estudos desenvolvidos por Bernd Heine \& Tania Kuteva (1996) e Shana Poplack(1991) foram eleitos como base dos fundamentos teóricos aqui utilizados.

O contato estabelecido entre mim e os entrevistados sempre se deu através de terceiros, por isso, ao me encontrar com alguns possíveis informantes soube sobre elementos de suas vidas que apresentavam incoerências em relação a este estudo. Tais como: dois "informantes" não eram de fato alemães, eram descendentes bilíngues; um terceiro "informante" estava no Brasil há pouco menos de um ano, fato que demonstrou não ter havido tempo suficiente para uma estabilidade na comunicação em língua portuguesa, ou seja, ainda estava em processo de aprendizagem de L2; um quarto "informante" sabendo com antecedência de minha visita, preparou um texto escrito com algumas histórias acerca de sua vida e acabou por dirigir, insistentemente, a entrevista; e, por fim, o quinto informante frequentava o mesmo clube e igreja que outro entrevistado. Dentre as 10 (dez) entrevistas feitas, portanto, cinco foram descartadas por não obedecerem aos critérios estabelecidos para esta pesquisa. 
Critérios estabelecidos para a escolha dos informantes:

- Ser alemão nativo e culto;

- Ser adulto acima de trinta anos;

- Ser residente na cidade de São Paulo há, pelo menos, cinco anos;

- De preferência, não frequentar os mesmos clubes, igrejas e outras instituições de caráter cultural alemão a menos que seja um ambiente profissional;

- Estar totalmente integrado à comunidade paulistana;

- Não houve preocupação em estudar comparativamente o comportamento de homens e mulheres em relação ao uso de L2, todos foram considerados somente alemães bilíngues.

Portanto, o quadro de informantes e respectivos dados produzidos é o seguinte:

\begin{tabular}{|l|l|l|l|}
\hline & tempo no Brasil & tempo no Brasil & tempo no Brasil \\
\hline feminino & 7 anos (Inf.3) & 5 anos (Inf.5) & \\
\hline masculino & 56 anos (Inf.1) & 10 anos (Inf.2) & 8 anos (Inf.4) \\
\hline
\end{tabular}

Feitas as entrevistas e transcritos os trechos relativos à ocorrência da estrutura sob análise, adotei os critérios utilizados por Sartin (2008) a fim de verificar se existiriam nuanças semânticas como aquelas surpreendidas em produções de jovens e em falas de adultos, tal como demonstrou a autora em seu trabalho. 
Analisando, no entanto, somente as ocorrências produzidas em português, não seria possível identificar indícios de um possível processo de replicação da L1 para a L2. Dessa forma, constituí nova amostra de controle a partir de língua escrita por alemães nativos, para que eu pudesse estabelecer uma comparação mais adequada.

Como já expliquei anteriormente, no Capítulo 1, decidi por duas diferentes amostras para a comparação: uma delas constituída pelas mesmas orações produzidas pelos informantes, porém traduzidas para a língua alemã por um colaborador alemão nativo que não concedeu nenhuma entrevista. Essa amostra serviu para identificar se há uma correlação entre as ocorrências de para+infinitivo no português e no alemão. A segunda amostra constituída por dados coletados de fóruns de discussão disponibilizados pelo jornal digital alemão Deutsch Welle e por dados coletados de um blog pertencente ao mesmo jornal, produzido por um jornalista e aventureiro a respeito de uma viagem que fazia à Antártida. A justificativa para a escolha desses elementos se deve à credibilidade ao jornal Deutsch Well e ao fator espontaneidade, ou seja, a linguagem, ainda que obedeça à maioria das regras do padrão culto alemão, apresenta muitos elementos coloquiais, favorecendo o emprego de usos inovadores.

O resultado dessa estratégia metodológica permitiu que eu aplicasse os critérios de Sartin (2008) de modo satisfatório (utilizando a codificação indicada abaixo). A quantificação foi feita tomando como critério central o valor semântico. Então analisei:

valor semântico x polaridade; valor semântico x identidade de sujeitos; valor semântico x material interveniente; e valor semântico x estrutura formal, para os itens 1,2 e 3 conforme segue:

\subsection{Análise do corpus em português produzido pelos informantes entrevistados}


(20 ocorrências)

\section{Estrutura formal:}

1. para + verbo

2. $0+$ verbo

3. para+0 (verbo subentendido)

\section{Material interveniente:}

n - não há material interveniente

$\mathrm{p}$ - pronome pessoal

$\mathrm{d}$ - pronome demonstrativo

$\mathrm{s}$ - sintagma nominal

o - oração

\section{Valor semântico:}

$\mathrm{f}$ - finalidade

e - encaixada - desempenha a função de sujeito, de objeto direto etc.

d - discursiva - tem relação com o ato de fala, com o discurso e não com uma ideia relatada

a - ambígua - pode ser final e também causal ou outra circunstância

\section{Polaridade:}

p - positiva

n - negativa 
$\mathrm{s}-\operatorname{sim}$

n - não

a) Estrutura formal - os dados recolhidos para análise puderam ser agrupados em três tipos de estrutura:

para + verbo: 1nfpn (56) (...)eu fiquei bem distante de alemães...porque para aprender a língua você precisa falar com o povo(...) - inf. 4

$0+$ verbo: 2ofps $(67)(\ldots)$ ah, isso é difícil dizer ... eu escolhi o Brasil pra ...eu vim de propósito, né?...queria vim ao Brasil... morar aqui... eu gosto... - inf.4

para+0: 3dfpn (73) (...)eu trabalhei, ãã, volunta/não voluntariamente, não, como free lancer para uma revista brasileira-alemã, então para isso (acontecer).... - inf.4

b) Material interveniente - nos dados colecionados por Sartin, a autora identificou três tipos de materiais nesse contexto:

pronome: 3dfpn (73) (...)eu trabalhei, ãã, volunta/não voluntariamente, não, como free lancer para uma revista brasileira-alemã, então para isso (acontecer).... - inf.4

sintagma nominal: 2sfps (72)(...)isso é minha experiência aqui...tudo faça para...para...as coisas acontecer(...) - inf.4

oração: 2ofps $(67)(. .$.$) ah, isso é difícil dizer ... eu escolhi o Brasil pra...eu vim de$ propósito, né?...queria vim ao Brasil... morar aqui... eu gosto... - inf.4 
c) Valor semântico: as orações formam um conjunto em que todos os elementos constituintes apresentam o valor semântico de finalidade, no entanto tal valor não aparece sempre explicitado pela estrutura para + infinitivo, existem, segundo Sartin(2008), "cinco nuanças semânticas":

finalidade: 1nfps (57)(...) eu acho que na Alemanha ... nas Universidades ... não tem muitos lugares para estudar português, né?(...) - inf.5

desbotamento semântico: não foi encontrada nenhuma ocorrência

encaixamento: 1nepn (59)(...) eu pediu alguém para dar uma olhada(...) - inf.3

ambiguidade: 1nann (64)(...)língua português tem, é, também um pouco de influência pra inglês, por exemplo, muitas palavras, né...também da língua francesa ... e esse coisas...pra falar depende sempre também a pessoas $(. .$.$) - inf.4$

discursiva: 1ndns (60)(...)de fazer uma coisa melhor...C: interessante...isso eu nunca tinha ouvido...M: mas, mas... só pra completar talvez, mas às vezes, eu sou aqui responsável pelos projetos culturais.(..) - inf. 3

d) Polaridade: quando uma oração subordinada apresenta o valor semântico de finalidade, segundo Sartin, espera-se uma polaridade positiva. Ou seja, já que a ideia de finalidade transmite a possibilidade e o desejo de se alcançar um objetivo, espera-se que 
este seja de fato conquistado. Por isso, uma polaridade negativa, por sua vez, teria a capacidade de alterar o valor semântico original dessas orações, porém ela não é somente aprendida em orações negativas, mas ainda em orações afirmativas com itens de polaridade negativa (com marcação não-explícita).

Polaridade positiva: 1nfps (58)(...) então, é, no curso a mesma coisa ... o que eu fiz para entregar $(. .)-.\inf .3$

Polaridade negativa: 1nens (61)(...)por isso até hoje, né, eu entender mais com eu falar, né? ler, é claro, é um problema, mas também pra conversar é um pouco difícil...língua portuguesa já/já difícil(...) - inf. 2 - sujeito

e) identidade entre sujeitos: a correferencialidade de sujeitos pode indicar uma maior gramaticalização, já que em orações finais os sujeitos são tipicmente diferentes.

correferenciais: 1nens (65)(...)que eu não trabalho como professor aqui, mas eu acho que pra trabalha é igual(...) - inf.2

não-correferenciais: 1nfpn (74) (...)eu fiquei bem distante de alemães...porque para aprender a língua você precisa falar com o povo(...) - inf.5

Tabulando esses dados com base nos critérios adotados, verifico que há indícios de gradação de sentidos:

Tabela 1: polaridade x função semântica

\begin{tabular}{|l|l|l|}
\hline função semântica & polaridade positiva & polaridade negativa \\
\hline
\end{tabular}




\begin{tabular}{|l|l|l|}
\hline finalidade & 10 & 1 \\
\hline $\begin{array}{l}\text { desbotamento } \\
\text { semântico }\end{array}$ & Não há & Não há \\
\hline ambígua & 1 & 1 \\
\hline discursiva & Não há & 1 \\
\hline encaixada & 1 & 2 \\
\hline Total & 12 & 5 \\
\hline
\end{tabular}

A tabela 1 indica que há uma frequência de $60 \%$ de polaridade positiva e $25 \%$ de polaridade negativa. Dentre aquelas que apresentaram polaridade positiva, $50 \%$ apresentam como valor semântico a finalidade, 5\% apresentam ambiguidade e 5\% apresentam encaixamento. Dentre aquelas que apresentaram polaridade negativa, 5\% apresentaram como valor semântico a finalidade, 5\% apresentaram ambigudade e $10 \%$ apresentaram encaixamento. Maior frequência de polaridade positiva com valor de finalidade.

Tabela 2: identidade dos sujeitos x função semântica

\begin{tabular}{|l|l|l|}
\hline função semântica & Identidade entre sujeitos & Não há identidade entre sujeitos \\
\hline finalidade & 7 & 4 \\
\hline $\begin{array}{l}\text { desbotamento } \\
\text { semântico }\end{array}$ & 0 & 0 \\
\hline ambígua & 1 & 1 \\
\hline discursiva & 1 & 0 \\
\hline encaixada & 2 & 1 \\
\hline Total & 11 & 6 \\
\hline
\end{tabular}

A tabela 2 indica, entre os dados, uma frequência maior de identidade de sujeitos, $55 \%$, sendo que $35 \%$ apresentam finalidade, $5 \%$ apresentam ambiguidade, 5\% discursividade e $10 \%$ apresentam encaixamento como valor semântico. Maior frequência de identidade de sujeitos com valor de finalidade.

Tabela 3: Material interveniente x função semântica

\begin{tabular}{|l|l|l|l|l|l|}
\hline função semântica & $\begin{array}{l}\text { Não } \\
\text { material }\end{array}$ & $\begin{array}{l}\text { Prono- } \\
\text { me }\end{array}$ & $\begin{array}{l}\text { Pronome } \\
\text { demonstrati- }\end{array}$ & $\begin{array}{l}\text { Sintag- } \\
\text { ma }\end{array}$ & oração \\
\hline
\end{tabular}




\begin{tabular}{|l|l|l|l|l|l|}
\hline & $\begin{array}{l}\text { interveni- } \\
\text { ente }\end{array}$ & pessoal & vo & nominal & \\
\hline finalidade & 8 & 0 & 1 & 1 & 1 \\
\hline $\begin{array}{l}\text { desbotamento } \\
\text { semântico }\end{array}$ & 0 & 0 & 0 & 0 & 0 \\
\hline ambígua & 2 & 0 & 0 & 0 & 0 \\
\hline discursiva & 1 & 0 & 0 & 0 & 0 \\
\hline encaixada & 3 & 0 & 0 & 0 & 0 \\
\hline Total & 14 & 0 & 1 & 1 & 1 \\
\hline
\end{tabular}

A tabela 3 demonstra que a maior frequência é de ocorrências com valor semântico de finalidade e sem material interveniente, $40 \%$. Ainda entre os dados que não apresentam material interveniente, $10 \%$ apresentam ambiguidade, 5\% discursividade e 15\% apresentam encaixamento. E demonstra, também, a ocorrência de $15 \%$ de frequência com material interveniente sendo $5 \%$ de pronome demonstrativo, $5 \%$ de sintagma nominal e $5 \%$ de oração.

Tabela 4: Estrutura formal x função semântica

\begin{tabular}{|l|l|l|l|}
\hline função semântica & Para + verbo & O+ verbo & $\begin{array}{l}\text { Para + verbo } \\
\text { (subentendido })\end{array}$ \\
\hline finalidade & 7 & 2 & 2 \\
\hline $\begin{array}{l}\text { desbotamento } \\
\text { semântico }\end{array}$ & 0 & 0 & 0 \\
\hline ambígua & 2 & 0 & 0 \\
\hline discursiva & 1 & 0 & 0 \\
\hline encaixada & 3 & 0 & 0 \\
\hline Total & 13 & 2 & 2 \\
\hline
\end{tabular}

Por fim, a tabela 4 demonstra que a maioria dos dados analisados apresentam a estrutura para + verbo, $65 \%$, sendo que $35 \%$ apresentam valor semântico de finalidade, $10 \%$ de ambiguidade, $5 \%$ de discursividade e $15 \%$ de encaixamento. A estrutura $0+$ verbo assim como a estrutura para + verbo (subentendido) apresentaram $10 \%$ de frequência cada uma, ambas com valor de finalidade.

\subsection{Análise do corpus constituído por elementos retirados do jornal Deutsch Welle} e do site de fóruns de discussão "Tagesschau" 
(29 ocorrências)

Códigos utilizados para a análise:

\section{Estrutura formal:}

1. $u m \ldots z u$

2. $z u+$ infinitivo;

3. damit

\section{Material interveniente:}

n - não há material interveniente

$\mathrm{p}$ - pronome pessoal

$\mathrm{d}$ - pronome demonstrativo

$\mathrm{s}$ - sintagma nominal

o - oração

\section{Valor semântico:}

$\mathrm{f}$ - finalidade

e - encaixada - desempenha a função de sujeito, de objeto direto etc.

d - discursiva - tem relação com o ato de fala, com o discurso e não com uma ideia relatada

a - ambígua - pode ser final e também causal ou outra circunstância

$\mathrm{v}$ - a estrutura somente indica o verbo principal da oração no infinitivo

\section{Polaridade:}

$\mathrm{p}$ - positiva

n - negativa 


\section{Identidade entre sujeitos}

$\mathrm{s}-\operatorname{sim}$

n - não

A língua alemã apresenta muitas especificidades em relação ao uso de grande parte de seu léxico e de estruturas, como ocorre em muitas línguas. Tais especificidades, aplicadas à estrutura sob análise neste trabalho, traduz-se na escolha correta entre duas maneiras de codificação: $u m . . . z u$, quando o sujeito da oração subordinada coincidir com o sujeito da oração-núcleo, ou damit, quando o sujeito da oração final não for o mesmo da oração-núcleo.

Em geral, as gramáticas normativas da língua alemã, ou seja, aquelas que transmitem os modelos associados à variedade culta, chamada de Hochdeutsch, descrevem exatamente essas duas variantes para a codificação de finalidade. No entanto, como é de conhecimento geral daqueles que estudam e analisam ocorrências do discurso oral ou escrito coloquial, existem grandes diferenças entre o discurso que obedece aos padrões normativos de uma língua e o discurso informal/coloquial, quanto à utilização de determinadas palavras e construções. Tal diferenciação é uma das motivações para os que estudam a gramaticalização como um processo iniciarem suas reflexões.

Analisando o português falado pelos informantes alemães, identifiquei ocorrências da estrutura para $+v$ infinitivo que não apresentavam valor semântico 
exclusivo de finalidade, revelando novas nuances semânticas, conforme apresentado anteriormente nas tabelas 1, 2, 3 e 4 .

E, analisando o corpus constituído por elementos retirados do jornal Deutsch Welle, encontrei ocorrências das três estruturas de infinitivo do alemão: $z u+$ infinitivo, um...zu e damit + infinitivo, conforme segue:

\section{b.1) Estrutura formal (tabela 8):}

$u m$... zu:

(76) Bitte einloggen, um zu antworten! (Por favor, acesse para responder!) (Deustch Welle)

(88)Obwohl von mir gelesen, ist es komisch zum Party-Smalltalk über einen Carmelengo zu parlieren, der eine Antimaterie-Explosion über Rom herberführt, um dann mit einem $\quad$ Fallschirm abzuspringen. (http://forum.spiegel.de/showthread.php?t=62)

Apesar de lido por mim, é engraçado para Party-Smalltalk falar sobre um Carmelengo que trouxe uma explosão de anti-matérias sobre a Roma, para depois saltar de páraquedas

Com exceção do exemplo 88, todos os demais elementos que apresentam a estrutura $u m \ldots z u, 16$ dados no total, deixam bem clara a ideia de finalidade. O exemplo 88, no entanto, apresenta com maior ênfase a noção de tempo ao invés de finalidade, sugerindo ambiguidade. 
(93) Die Ausstellung ist bis 20. April im Museum "Complesso del Vittoriano" in Rom zu sehen. (Ver a exposição até 20 de abril no museu "Complesso del Vittoriano" em Roma.) (Deustch Welle)

Nenhum dos exemplos, 6 no total, apresentou uma ideia de finalidade ao invés de somente indicar que o verbo está no infinitivo $(z u+v e r b o)$.

Damit + infinitivo ( 6 dados no total):

(98) Ganze vier Tage brauchte im Sommer 2008 das deutsche Forschungsschiff Polarstern(...)und damit in gut zwei Monaten den Nordpol komplett umrundete. (Todos os quatro dias serão necessários, no verão de 2008 , ao navio de investigação alemão Polarstern, (...), e para que complete a circunavegação pelo pólo norte em bons dois meses. (Deutsch Welle)

(99) "Da muss man sehr genau nachrechnen, damit man nicht nur ins Eis hineinfährt, sondern auch wieder heraus. (...)" ("Então você tem que calcular muito cuidadosamente para que você não caia dentro do gelo, mas também volte para fora. (,,,)"(Deustch Welle)

O que as gramáticas normativas da língua alemã em geral apresentam, é que a conjunção damit deve ser utilizada para expressar a ideia de finalidade quando não houver a correspondência entre o sujeito da oração principal e o sujeito da oração subordinada. No entanto, pode-se observar que o exemplo 99 indica que os sujeitos de ambas as orações são, exatamente, o mesmo. Nesse caso, então, o mais correto, segundo o Hochdeustch, seria utilizar a expressão conjuntiva um...zu, ao invés de damit. 
b.2) Material interveniente (tabela 7): Só foi possível analisar o material interveniente nas orações que apresentam a estrutura $u m \ldots z u$. Como se pode observar, a estrutura possibilita a existência de um material interveniente que, no caso, é toda a oração subordinada final, menos o verbo que se apresenta no infinitivo, pois esse aparece somente ao final da estrutura. Dos 16 dados, 8 (50\%) apresentaram a oração como material interveniente e $8(50 \%)$ não apresentaram qualquer tipo de material interveniente.

(85) "Viren brauchen Lebewesen, um zu überleben und sich zu vermehren. (Precisa de um ser vivo, para sobreviver e para multiplicar-se.) (Deustch Welle)

\section{b.3) Valor semântico (tabelas 5, 6, 7 e 8):}

. Entre os dados que apresentam a estrutura um...zu, somente o exemplo 88 pode apresentar a ideia de tempo. No entanto, como foi descrito no capítulo 4, "Replicação da estrutura v+para+infinitivo no Português L2", item b1, a estrutura é utilizada pelos alemães também para indicar situações temporais.

. Entre os dados que apresentam a estrutura zu+infinitivo, 6 no total, o exemplo 92 deixa uma dúvida quanto à sua significação, indicando ambiguidade (16,66\% de frequência), os demais $83,34 \%$ indicam finalidade.

. Entre os dados que apresentam a estrutura damit, 6 no total, encontrei exemplos que indicam finalidade $(66,66 \%)$ e desbotamento $(33,33 \%)$.

\section{b.4) Polaridade (tabela 5):}

. Entre os dados que apresentam a estrutura um...zu: somente o exemplo 87 apresenta a polaridade negativa +positiva $(6,25 \%$ do total de dados "um...zu);

\section{b.5) identidade entre sujeitos (tabela 6):}


. Entre os dados que apresentam a estrutura $u m . . . z u$ : todos os dados obedecem à estrutura padrão da língua, ou seja, há correferencialidade entre os sujeitos.

. Entre os dados que apresentam a estrutura damit: os exemplos 98 e 99 apresentam correferencialidade entre os sujeitos, portanto, a estrutura correta, segundo o padrão da língua, seria $u m \ldots z u$.

Tabela 5: polaridade x função semântica para todas as estruturas

\begin{tabular}{|l|l|l|}
\hline função semântica & polaridade positiva & polaridade negativa \\
\hline finalidade & 16 & 5 \\
\hline $\begin{array}{l}\text { desbotamento } \\
\text { semântico }\end{array}$ & 0 & 0 \\
\hline ambígua & 3 & 0 \\
\hline discursiva & 0 & 0 \\
\hline encaixada & 0 & 0 \\
\hline $\begin{array}{l}\text { Verbo principal no } \\
\text { infinitivo }\end{array}$ & 4 & 0 \\
\hline Total & 23 & 5 \\
\hline
\end{tabular}

Tabela 6: identidade dos sujeitos x função semântica para todas as estruturas

\begin{tabular}{|l|l|l|}
\hline função semântica & Identidade entre sujeitos & Não há identidade entre sujeitos \\
\hline finalidade & 16 & 5 \\
\hline $\begin{array}{l}\text { desbotamento } \\
\text { semântico }\end{array}$ & 0 & 0 \\
\hline ambígua & 3 & 0 \\
\hline discursiva & 0 & 0 \\
\hline encaixada & 0 & 0 \\
\hline $\begin{array}{l}\text { Verbo principal no } \\
\text { infinitivo }\end{array}$ & 3 & 1 \\
\hline Total & 22 & 6 \\
\hline
\end{tabular}

Tabela 7: Material interveniente x função semântica para todas as estruturas

\begin{tabular}{|l|l|l|l|l|l|}
\hline função semântica & $\begin{array}{l}\text { Não há } \\
\text { material } \\
\text { interveni- } \\
\text { ente }\end{array}$ & $\begin{array}{l}\text { Prono- } \\
\text { me } \\
\text { pessoal }\end{array}$ & $\begin{array}{l}\text { Pronome } \\
\text { demonstrati- } \\
\text { vo }\end{array}$ & $\begin{array}{l}\text { Sintag- } \\
\text { ma } \\
\text { nominal }\end{array}$ & oração \\
\hline finalidade & 14 & 0 & 0 & 3 & 4 \\
\hline
\end{tabular}




\begin{tabular}{|l|l|l|l|l|l|}
\hline $\begin{array}{l}\text { desbotamento } \\
\text { semântico }\end{array}$ & 0 & 0 & 0 & 0 & 0 \\
\hline ambígua & 2 & 0 & 0 & 0 & 0 \\
\hline discursiva & 0 & 0 & 0 & 0 & 0 \\
\hline encaixada indica & 0 & 0 & 0 & 0 & 0 \\
\hline $\begin{array}{l}\text { Somente principal no } \\
\text { verbo } \\
\text { infinitivo }\end{array}$ & 0 & 0 & 0 & 0 \\
\hline Total & 20 & & & 3 & 4 \\
\hline
\end{tabular}

Tabela 8: Estrutura formal x função semântica para todas as estruturas

\begin{tabular}{|l|l|l|l|}
\hline função semântica & Um ...zu & $\begin{array}{l}\text { Zu+ verbo no } \\
\text { infitivo }\end{array}$ & Damit \\
\hline finalidade & 15 & 0 & 6 \\
\hline $\begin{array}{l}\text { desbotamento } \\
\text { semântico }\end{array}$ & 0 & 0 & 0 \\
\hline ambígua & 1 & 2 & 0 \\
\hline discursiva & 0 & 0 & 0 \\
\hline encaixada & 0 & 0 & 0 \\
\hline $\begin{array}{l}\text { Verbo principal no } \\
\text { infinitivo }\end{array}$ & 0 & 4 & 0 \\
\hline Total & 15 & 4 & 6 \\
\hline
\end{tabular}

3.3. Análise da tradução para o alemão do corpus produzido pelos informantes entrevistados

Códigos utilizados para a análise:

\section{Estrutura formal:}

1. um...zu

2. $z u+$ infinitivo;

3. damit;

4. für.

5. somente o verbo

Material interveniente: 
n - não há material interveniente

$\mathrm{p}$ - pronome pessoal

$\mathrm{d}$ - pronome demonstrativo

$\mathrm{s}$ - sintagma nominal

o - oração

a - advérbio

\section{Valor semântico:}

$\mathrm{f}$ - finalidade

e - encaixada - desempenha a função de sujeito, de objeto direto etc.

d - discursiva - tem relação com o ato de fala, com o discurso e não com uma ideia relatada

a - ambígua - pode ser final e também causal ou outra circunstância

$\mathrm{v}-\mathrm{a}$ estrutura somente indica o verbo principal da oração no infinitivo

1 - local, direção ou para +algo ou alguém.

\section{Polaridade:}

$\mathrm{p}$ - positiva

n - negativa

\section{Identidade entre sujeitos}

s - sim

n - não

\section{c.1) Estrutura formal (tabela 12)-}


um...zu (para+infinitivo):

(104) Ich bliebe von den Deutsch entfern denn um eine Sprache kennenzulernen musst du mit von gesprechen.

(...)eu fiquei bem distante de alemães...porque para aprender a língua você precisa falar com o povo(...) - inf 4

$z u+v e r b o$ no infinitivo:

(106) dann, der Kurs ist immer das gleiche...was ich getan habe zu liefern

(...) então, é, no curso a mesma coisa ... o que eu fiz para entregar(...) - inf. 3

Für:

(118) (...)ruhig, keine Verantwortung für alles(...)

(...)C: eu gostaria de saber como você definiria o povo brasileiro...qual a maior característica que faz com ele seja bem diferente dos alemães...G: tranquila, sem responsabilidade para nada(..) - inf. 3

O colaborador alemão não entendeu os exemplos 112 e 115 como ideia de finalidade, dessa forma, traduziu os dados da seguinte forma:

(116)(...)dann ist diese... nach der Arbeit an der Universität ging zum Interview(...)

(...)então para isso .... após o trabalho na universidade fui para entrevista(...)

(119) (...)ich ging einmal dort zur Hochzeit meiner Tochter(...)

(...) eu fui uma vez lá pra casamento do meu filha (...) 
Assim, percebi que o colaborador entendeu "entrevista" e "casamento" como eventos, portanto a ideia subentendida de finalidade ("para fazer uma entrevista" e "para assistir ao casamento") não correspondeu com minha análise inicial.

c.2) Material interveniente (tabela 11) - A própria estrutura final $u m \ldots z u$ sugere uma pos-

sível presença de material interveniente.

(verbo no infinitivo)

(105) Ich glaube dass in Deutschland na den Universitäten wenig Platz ist um Portugiesisch zu lernen.

(...) eu acho que na Alemanha ... nas Universidades ... não tem muitos lugares para estudar português, né?(...) - inf. 5

c.3) Valor semântico (tabelas 9, 10, 11 e 12): O valor semântico de cada dado foi avaliado segundo sua própria estrutura formal:

valor de finalidade:

(105) Ich glaube dass in Deutschland na den Universitäten wenig Platz ist um Portugiesisch zu lernen.

(...) eu acho que na Alemanha ... nas Universidades ... não tem muitos lugares para estudar português, né?(...) - inf. 5

desbotamento semântico:

não há;

encaixamento: 
(115) Das ist schwierig zu sagen... ich habe Brazilien aus gesucht ich bin bewusst gekommen. Ich wollte nach Brasil hier wohnen mir gefällte es ist alles gut aber ich kam nicht sagen fallt ist nicht züruckgehen aber ich kam auch hier bleiben.

(...)ah, isso é difícil dizer ... eu escolhi o Brasil pra...eu vim de propósito, né?...queria vim ao Brasil... morar aqui... eu gosto... - inf. 4

\section{ambiguidade:}

(107) Ich batt jemand es anzuschauen

(...) eu pediu alguém para dar uma olhada(...) - inf. 3

Os exemplos 116 e 119, segundo a tradução para o alemão, não indicariam nenhuma ideia de finalidade. O exemplo 118 apresenta a preposição für que pode apresentar como significados "para, por ou a favor de" acompanhando objetos diretos. No entanto, o s exemplo deixa um verbo implícito, como "para fazer nada" (ex. 118). Portanto, conclui que esse exemplo pertence à ambiguidade como valor semântico.

c.4) Polaridade (tabela 9): Aplicando aos dados, identifiquei as seguintes combinações nas orações:

positivo + positivo

(110) (...)lernen ... manchmal habe ich zum Beispiel etwas mehr (?) unvollkommen, perfekte, zum Beispiel, nicht wahr? sondern nur zu reden und zu hören, nicht wahr?(...) 
(...)aprendo...às vezes eu, por exemplo, pouco mais (?) imperfeito, perfeito, por exemplo, né? mas só pra falar e ouvir, né?(...) - inf. 2

negativo + positivo

(117) Ich finde dass es viel Deutsch zum Beispiel nicht gut ist sich im Klub oder Erliches zu treffen. Kürche ja aber... ich schätze nicht und war auch nie dafür

(...)Eu não gosta disso. Instituto eu acho...bastante ... e também eu acho não bom para alemãos, por exemplo. eles reunion para clubes, ou qualquer coisa... - inf. 2

\section{c.5) identidade entre sujeitos (tabela 10):}

\section{correferencialidade dos sujeitos}

(109) Also bis Heute vorstehe ich mehr alzusprechen lesen ist ein Problem aber auch

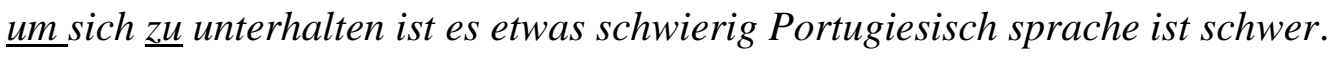

(...)por isso até hoje, né, eu entender mais com eu falar, né? ler, é claro, é um problema, mas também pra conversar é um pouco difícil...língua portuguesa já/já difícil(...)- inf.2

\section{não-correferencialidade dos sujeitos}

(104) Ich bliebe von den Deutsch entfern denn um eine Sprache kennenzulernen musst du mit von gesprechen.

(...)eu fiquei bem distante de alemães...porque para aprender a língua você precisa falar com o povo(...) - inf 4

Tabela 9: polaridade x função semântica para todas as estruturas 


\begin{tabular}{|l|l|l|}
\hline função semântica & polaridade positiva & polaridade negativa \\
\hline finalidade & 8 & 4 \\
\hline $\begin{array}{l}\text { desbotamento } \\
\text { semântico }\end{array}$ & 0 & 0 \\
\hline ambígua & 0 & 2 \\
\hline discursiva & 0 & 0 \\
\hline encaixada & 1 & 1 \\
\hline $\begin{array}{l}\text { Verbo principal no } \\
\text { infinitivo }\end{array}$ & 2 & 0 \\
\hline $\begin{array}{l}\text { Local, direção ou } \\
\text { para+algo ou alguém }\end{array}$ & 3 & 0 \\
\hline Total & 14 & 6 \\
\hline
\end{tabular}

Tabela 10: identidade dos sujeitos x função semântica para todas as estruturas

\begin{tabular}{|l|l|l|}
\hline função semântica & Identidade entre sujeitos & Não há identidade entre sujeitos \\
\hline finalidade & 8 & 3 \\
\hline $\begin{array}{l}\text { desbotamento } \\
\text { semântico }\end{array}$ & 0 & 0 \\
\hline ambígua & 1 & 1 \\
\hline discursiva & 0 & 0 \\
\hline encaixada & 1 & 1 \\
\hline $\begin{array}{l}\text { Verbo principal no } \\
\text { infinitivo }\end{array}$ & 1 & 2 \\
\hline $\begin{array}{l}\text { Local, direção ou } \\
\text { para+algo ou alguém }\end{array}$ & 3 & 0 \\
\hline Total & 14 & 7 \\
\hline
\end{tabular}

Tabela 11: Material interveniente x função semântica para todas as estruturas

\begin{tabular}{|l|l|l|l|l|l|l|}
\hline função semântica & $\begin{array}{l}\text { Não há } \\
\text { material } \\
\text { interveni- } \\
\text { ente }\end{array}$ & $\begin{array}{l}\text { Prono- } \\
\text { me } \\
\text { pessoa } \\
1\end{array}$ & $\begin{array}{l}\text { Pronome } \\
\text { demonstra } \\
\text {-tivo }\end{array}$ & $\begin{array}{l}\text { Sintag- } \\
\text { ma } \\
\text { nominal }\end{array}$ & $\begin{array}{l}\text { Ad } \\
\text { vér } \\
\text { bio }\end{array}$ & $\begin{array}{l}\text { Ora } \\
\text { ção }\end{array}$ \\
\hline finalidade & 1 & 0 & 0 & 5 & 3 & 2 \\
\hline $\begin{array}{l}\text { desbotamento } \\
\text { semântico }\end{array}$ & 0 & 0 & 0 & 0 & 0 & 0 \\
\hline ambígua & 0 & 0 & 0 & 0 & 1 & 1 \\
\hline discursiva & 0 & 0 & 0 & 0 & 0 & 0 \\
\hline encaixada no & 1 & 1 & 0 & 0 & 0 & 0 \\
\hline $\begin{array}{l}\text { Somente verbo principal no } \\
\text { infinitivo }\end{array}$ & 2 & 0 & 0 & 0 & 0 & 0 \\
\hline $\begin{array}{l}\text { Local, direção ou } \\
\text { para+algo ou alguém }\end{array}$ & 3 & 0 & 0 & 0 & 0 & 0 \\
\hline Total & 7 & 1 & 0 & 5 & 4 & 3 \\
\hline
\end{tabular}


Tabela 12: Estrutura formal x função semântica para todas as estruturas

\begin{tabular}{|l|l|l|l|l|l|}
\hline função semântica & Um ... zu & $\begin{array}{l}\text { Zu+ } \\
\text { verbo no } \\
\text { infitivo }\end{array}$ & Damit & Für & $\begin{array}{l}\text { Somen- } \\
\text { te o } \\
\text { verbo }\end{array}$ \\
\hline finalidade & 10 & 0 & 0 & 0 & 5 \\
\hline $\begin{array}{l}\text { desbotamento } \\
\text { semântico }\end{array}$ & 0 & 0 & 0 & 0 & 0 \\
\hline ambígua & 2 & 0 & 0 & 0 & 0 \\
\hline discursiva & 0 & 0 & 0 & 0 & 0 \\
\hline encaixada & 1 & 1 & 0 & 0 & 0 \\
\hline $\begin{array}{l}\text { Verbo principal no } \\
\text { infinitivo }\end{array}$ & 0 & 2 & 0 & 0 & 0 \\
\hline $\begin{array}{l}\text { Local, direção ou } \\
\text { para+algo ou alguém }\end{array}$ & 0 & 0 & 0 & 3 & 0 \\
\hline Total & 13 & 3 & 0 & 3 & 3 \\
\hline
\end{tabular}

Uma questão emerge dessas constatações: o indício de gramaticalização verificado no discurso em português dos informantes seria uma internalização - ou aprendizagem - de tal estrutura da própria língua portuguesa, ou haveria uma replicação de uma estrutura que em alemão também estaria passando pelo processo de gramaticalização?

Para responder a essa questão, pesquisei a gramática de usos da língua alemã, Gramática Alemã, do autor Herbert Andreas Welker, que trata também da variante coloquial da língua alemã. A única informação diferenciada que consta dessa gramática foi a seguinte observação: "Em português, há outras conjunções que permitem o uso do infinitivo (antes de, apesar de, depois de). Nesses casos, em alemão só pode ser empregada uma oração subordinada, com uma forma finita do verbo.” (WELKER, pág. 52) 
A hipótese de gramaticalização do infinitivo alemão $u m$ (...) zu, que indica a ideia de finalidade numa relação entre orações num mesmo período, é a dessemantização (perda do sentido original).

Sabe-se que a gramaticalização ocorre, principalmente, em situações informais, em discursos mais coloquiais, pois são momentos nos quais as pessoas estão mais preocupadas em fazer-se entender que, necessariamente, seguir à risca todas as regras normativas de uma língua. Uma espécie de "licença linguística". Por esse motivo, para dar continuidade a essa pesquisa, além das transcrições das entrevistas em português feitas com os informantes alemães, era necessário colher material linguístico para estabelecer uma analogia entre o alemão padrão e o alemão coloquial e determinar se a gramaticalização da estrutura que indica finalidade $-u m \ldots z u$ - também poderia estar ocorrendo na língua alemã.

A estratégia que utilizei foi a de colher material de blogs alemães, escritos por cidadãos alemães para o jornal Deutsch Welle, ou mesmo debates promovidos também por esse jornal via internet. A análise de todo o corpus está apresentada no capítulo 5 a seguir. 


\section{Considerações finais}

Dentre os informantes, aquele que considerei o mais importante é o Inf.1, pois por apresentar a idade de 92 anos, foi o responsável por estabelecer uma conexão com a história social dos alemães na cidade de São Paulo apresentada no capítulo 3, “Aspectos da História social da imigração alemã: um olhar sobre São Paulo”. Os dados gerados por esse informante permitiram que eu fizesse uma análise para estabelecer se os desvios cometidos pelos outros alemães já aconteciam na metade do século XIX, época em que ele já estava estabelecido em São Paulo, há 56 anos, ou se são ocorrências mais novas. Além disso, auxiliou, também, na percepção dos desvios: se são cometidos por replicação, ou se acontecem somente em L2.

Essa análise foi possível, pois como foi apresentado no capítulo 1, item 2, o discurso em L2 gerado por alguém que mantém um contato com a língua há 5 anos, já está cristalizado, ou seja, já se encerrou o período do processo de aprendizagem de uma língua. Por isso, muito provavelmente, o tipo de linguagem apresentado pelo Inf. 1, é o mesmo que ele apresentava há 50 anos, quando já se encontrava estabelecido no Brasil há 6 anos.

As ocorrências da estrutura para + infinitivo da entrevista desse informante são:

(124) (...)o homem cozinha, assa, frita, grelha até cinzas a comida, que já era pronto para comer(...) - inf.1

(125) (...)remédios milagrosos de todos os tipos (...) somente são usados para suprimir os sintomas $(\ldots)-\inf .1$

(126) (...)eu querer voltar para ter uma saúde completa(...) - inf.1 
(127) (...)para comparar pegamos um homem de cinquenta anos(...)- inf.1

(128) (...)você precisa saber para querer(...) - inf.1

(129)Schultz mandou construir uma ampliação para a igreja, o coro (...) - inf.1

Os exemplos 125, 126 e 127 indicam, sem dúvida, a ideia de finalidade. Porém os exemplos 124 e 129 apresentam novas nuances semânticas. O exemplo 124 pode ser entendido, ainda, como orações encaixadas, podendo ser entendidas como "A comida estava pronta para ser 'comida'", O exemplo 126 apresenta ambiguidade, pois pode ser reescrito da seguinte forma: "Schultz mandou construir um coro, para ampliar a igreja", e nesse caso a relação de sentido seria de finalidade, ou "Schultz mandou construir uma ampliação, um coro, para a igreja”, ou seja, "para contribuir com a igreja", "para promover melhorias na igreja", "para dar à igreja", ou ainda, "para favorecer a igreja" e nesses últimos casos, estaríamos diante da nova estrutura definida por mim como para +0 (sendo 0, um verbo subentendido).

Por último, o exemplo 128 sugere a ideia de condição, indicando, portanto, um desbotamento semântico.

Os exemplos anteriores sugerem, então, que na metade do século XIX, já havia indícios de um processo de gramaticalização no português falado por alemães estabelecidos na cidade de São Paulo.

Em seguida, apresento algumas considerações a respeito dos três grupos de dados analisados: discurso em português dos informantes, tradução para o alemão do discurso dos informantes e dados colhidos de blogs e jornais digitais alemães:

1. Em relação ao processo de pidginização: 
O inf. 2 foi o único que apresentou maior dificuldade em relação à língua portuguesa. Durante a entrevista, percebi dificuldades com o vocabulário, com a correspondência entre os gêneros em alemão e português, algumas inversões sintáticas e a elipse de elementos dentro de orações tais como conjunções, preposições e verbos.

Levando-se em conta o que já foi conceituado a respeito do pidgin e aprendizagem de L2 no capítulo 1, "Fundamentação teórica", item 2.1, que "o pidgin, basicamente, 'é uma língua auxiliar que surge quando falantes de diversas línguas mutuamente ininteligíveis entram em contato estreito" " (COUTO, 1996) e que "o 'pidgin não é uma língua nativa de nenhum de seus usuários', 'é uma língua de emergência, de contato, drasticamente simplificada estruturalmente' " (Robert A. Hall Jr. apud Couto, 1996), posso concluir que somente o seu discurso (inf.2) apresentou uma estrutura próxima ao conceito de pidginização. No entanto, como sua L2 já apresenta-se cristalizada, ou seja, o informante não está mais no processo de aprendizagem de L2, e como a estrutura dessa mesma L2 diferencia-se bastante de sua L1 e da própria L2, concluo que seu discurso é próximo ao que chamaríamos de língua crioula.

Quando analisei os dados de seu discurso referentes à utilização da estrutura em português de para+infinitivo, identifiquei ocorrências (desvios) que levavam à ideia de finalidade, mas a estrutura se apresentava incompleta. Indiquei-as como estrutura formal para+O(sendo o 0 um verbo subentendido). São referentes aos exemplos 69 e 71 :

(69)(...)Eu não gosta disso. Instituto eu acho...bastante ... e também eu acho não bom para alemãos (“frequentar", por exemplo), por exemplo. eles reunion para clubes, ou qualquer coisa... - inf.2 
(71)(...) eu fui uma vez lá pra (“assistir ao”, por exemplo)casamento do meu filha (...) inf.2

Outros dois informantes, inf. 3 e inf.4, também produziram discursos em que essa mesma estrutura descrita anteriormente também aparece, exemplos 68 e 70: (68)(...)então para isso ("acontecer", por exemplo).... após o trabalho na universidade fui para ("fazer uma", por exemplo) entrevista (...) - inf.3

(70)(...) tranquila, sem responsabilidade para nada(..) - inf.4

Como já mencionei anteriormente, excetuando-se o inf. 2, todos os outros informantes apresentavam bastante fluência em L2, demonstrando amplo conhecimento vocabular e sobre a estruturação sintática da língua portuguesa. Portanto, não posso correlacionar a ocorrência dessa nova estrutura à fluência em L2 dos informantes.

No entanto, quando meu colaborador alemão traduziu tais ocorrências para a língua alemã, os exemplos 116 e 119 foram entendidos como local ou evento, portanto a preposição utilizada foi $z u$ contraída com artigos declinados no dativo (de maneira geral, o dativo corresponde ao objeto indireto da língua portuguesa). Para o exemplo 118, foi utilizada a preposição für formando um complemento nominal:

(118) (...)ruhig, keine Verantwortung für alles(...) 
(...)C: eu gostaria de saber como você definiria o povo brasileiro...qual a maior característica que faz com ele seja bem diferente dos alemães...G: tranquila, sem responsabilidade para nada(..) - inf. 3

Ou seja, nenhuma dessas ocorrências foi entendida como oração final. Esse fato é um grande indício de que somente na língua portuguesa proferida por alemães, eu poderia pressupor a nova estrutura gramatical para+O(sendo o 0 um verbo subentendido), pois a estrutura da oração em alemão não deixa dúvidas quanto ao entendimento como local ou evento para tais exemplos.

Estabelecendo uma comparação entre esses três informantes, posso concluir que as ocorrências 68, 69, 70 e 71 sejam resquícios de um processo de pidginização durante a aprendizagem de L2 que acabou permanecendo em seus discursos. Consequentemente, o processo de pidginização serviu como um grande estímulo para se desencadear um processo de gramaticalização em L2 a partir da “aparição" da nova estrutura.

2. Em relação ao processo de replicação:

Como já foi sugerido anteriormente neste trabalho, os informantes entrevistados por mim, passaram por um processo de aprendizagem informal, tal como os dados analisados por Heine \& Kuteva (2005). Os autores "vivenciaram experiências de contato linguístico sem intermediação do ensino formal. Da mesma forma, orientaram trabalhos que reforçaram suas intuições acerca dos efeitos de uma língua sobre a outra em situação comunicativa" (presente trabalho, capítulo 1, item 1.1). 
Baseei-me no trabalho desses dois autores para o desenvolvimento de meu estudo, pois possuo o mesmo objetivo: de maneira diferenciada em relação a estudos que analisam os efeitos de um contato linguístico, focalizando as interferências no léxico e na fonologia, também pretendo demonstrar a invalidade do axioma linguístico referente à ideia de que a gramática estaria imune a esses tipos de interferências.

Dentre os tipos de materiais linguísticos que geralmente sofrem replicação, segundo Heine \& Kuteva (2006), procurei ater-me às relações semântico- sintáticas (novos significados a elementos sintáticos significativos pré-existentes, bem como mudanças estruturais).

Segundo Heine \& Kuteva (2006), a replicação gramatical tem como condição necessária de manifestação um grau acentuado de bilinguismo extensivo (uma comunidade precisa se comunicar em L2 cotidianamente) ou de bilinguismo intensivo (um indivíduo é exigido, na L2, em situações diárias de interação) (presente trabalho, capítulo 1, item 1.1). Todos os informantes, exceto o inf.2, apresentam o bilinguismo intensivo.

Os autores indicam variáveis que podem desencadear a replicação e, segundo o contexto social de meus informantes, as que mais se destacam são: necessidades e intenções comunicativas, bem como o comportamento criativo ativado para o uso de recursos linguísticos avaliados de novas maneiras, dadas as grandes diferenças estruturais entre as duas línguas em questão, a língua portuguesa e a alemã.

Pareceu-me que meus informantes, tal como os autores descreveram em seus estudos, desenvolveram novas estruturas de expressão gramatical que lhes pareceram mais adequadas em determinadas situações, através da manipulação dos recursos linguísticos disponíveis. 
Se, segundo Heine \& Kuteva (2006) a "replicação gramatical por contato entre línguas ocorre quando um elemento gramatical Mx de uma língua $\mathrm{M}$, que servirá como modelo nesse contato, é replicado na língua R surgindo, assim, uma nova estrutura Rx", posso concluir que no presente trabalho $M$ refere-se à língua alemã, Mx refere-se à estrutura $u m . . . z u$ e damit, $\mathrm{R}$ refere-se à língua portuguesa e $\mathrm{Rx}$ refere-se aos desvios produzidos pelos informantes.

Entretanto, houve uma grande dificuldade para analisar as ocorrências em português, pois as estrutras alemãs $u m . . . z u$, für, damit e $z u$, ainda que semântica e gramaticalmente diferentes, quando traduzidas para o português apresentam basicamente o mesmo significado: "para". Por esse motivo, pedi a um colaborador que traduzisse para a língua alemã todas as ocorrências selecionadas, a fim de estabelecer uma comparação entre os correferentes em alemão e português.

Ao analisar as traduções, verifiquei que nem todas as estruturas apresentavam correspondência semântica, estabelecida, principalmente, pelas estruturas alemãs.

Como a língua alemã apresenta estruturas muito bem definidas para cada contexto, a tendência é que haja um número muito menor de ambiguidades e desbotamentos semânticos quanto aos valores semânticos de cada ocorrência. Foi exatamente o que percebi ao analisar as traduções. Como descrevi no parágrafo anterior, "nem todas as estruturas apresentavam correspondência semântica, estabelecida, principalmente, pelas estruturas alemãs”. Algumas estruturas, quando traduzidas, eliminavam a presença de ambiguidade, tais como os exemplos 116, 117, 118 e 119.

Todavia, as estruturas 107 , que apresenta a forma $z u+$ infinitivo indica que há um encaixamento, as estruturas 109 e 113, que apresentam a forma um ... zu também apresentam encaixamento e o exemplo 112 não deixa clara a ideia de que é oração 
subordinada reduzida de infinitivo ou oração subordinada final. Ou seja, mesmo em alemão, demonstram as nuances semânticas de encaixamento ou ambiguidade, acumulando dois valores sintáticos distintos. Esses mesmos exemplos indicam, portanto, o processo de gramaticalização ocorrendo na própria língua alemã.

Posso inferir daí que é possível a replicação ter ocorrido da língua alemã para a língua portuguesa L2, ainda que em nível semântico, já que a tradução das expressões alemãs para o português é exatamente a mesma, "para".

Para finalizar, cito, então, um argumento desenvolvido por Heine \& Kuteva (2006) para corroborar com minha conclusão: “a estrutura Rx não é inteiramente nova, pois ela é "construída” a partir de uma antiga estrutura Ry existente anteriormente em R e que a replicação transformou em Rx. Em outras palavras, a replicação não parte de um vazio, ao contrário, ela requer um discurso padrão apropriado na língua $\mathrm{R}$ para tomar lugar" (presente trabalho, capítulo 1, item 1.1).

\section{Em relação ao code-switching:}

O processo definido como code-switching por Shana Poplak (1991), segundo as explanações feitas no capítulo2, item 2, “é a combinação de sentenças, ou fragmentos de sentenças, pertencentes a dois sistemas gramaticais, ou subsistemas gramaticais a um mesmo ato de fala de falantes bilíngues. No entanto, as regras gramaticais desses dois sistemas não podem ser prejudicadas. Ou seja, ocorre a troca de uma língua para outra durante uma interação comunicativa justapondo-se num mesmo período L1 e L2 resultando numa estrutura sintática final mista e coerente. Tal troca é determinada pela função de cada língua no comportamento de cada indivíduo e pelo grau de competência em cada uma delas." 
Reavaliando os exemplos 68, 69, 70 e 71, percebo que se encaixam nas explanações que fiz a respeito de code-switching no capítulo 2:

"Enquanto o code-switching é, basica e literalmente, a alternância de sentenças, ou fragmentos de sentenças de diferentes línguas - estimulada por diversos fatores, na fala de um bilíngue, a gramaticalização no contato entre línguas apresenta-se como uma espécie de tradução dessas mesmas sentenças de L1 para L2, obedecendo-se a uma correspondência morfológica, fonética e/ou sintática com os elementos de L1, e encaixando-as em sentenças originais de L2 de modo que as alterações, ou adaptações ocorridas em L2 não sejam tão estranhas a ponto de tornar uma fala incoerente. Às vezes, trata-se de adaptações imperceptíveis ao próprio bilíngue. Portanto, de maneira geral, os dois processos baseiam-se em alternâncias, adaptações e substituições de sentenças (ou fragmentos de sentenças) de L1 em L2, ou vice-versa.”

Não houve, no processo de tradução, a percepção de verbos subentendidos nos exemplos citados acima, ocorrendo a substiuição literal dos sintagmas nominais sem a presença do verbo no infinitivo. Consequentemente, houve o surgimento de uma nova estrutura formal, para+O (sendo 0 um verbo subentendido).

Percebi, também, através das entrevistas feitas com os informantes, que algumas sentenças ou fragmentos de sentenças em alemão eram utilizados durante uma fala, quando o informante não conseguia encontrar um correspondente em português.

Logo, a partir dessas análises, pude entender ainda, que o code-switching pode funcionar como um estímulo para se chegar a um resultado final de um processo de gramaticalização no contato entre línguas. Como uma espécie de processo anterior à gramaticalização, alteram-se as duas línguas num mesmo período. De acordo com a adaptação do falante da língua alemã à língua portuguesa, ou seja, sua fluência em 
português, elementos fonéticos, morfológicos e sintáticos da língua alemã passam por uma espécie de "aportuguesamento" que resultaria na gramaticalização.

Os dados colhidos de blogs e jornais digitais alemães indicam poucos desvios semânticos quanto à utilização das estruturas um...zu, damit, zu+verbo no infinitivo $\mathrm{e}$ für, segundo a análise demonstrada. Das 29 ocorrências coletadas, somente 3 apresentaram desvios quanto à aplicação em contextos semânticos determinados: o exemplo 92, que apresenta a estrutura $z u+v e r b o$ no infinitivo, gera ambiguidade quanto à sua significação, podendo apresentar-se como reduzida de infinitivo ou subordinada final; os exemplos 94 e 95 apresentam correferencialidade entre os sujeitos das orações, devendo portanto, segundo o Hochdeutsch, apresentar a estrutura um...zu ao invés de damit, como foi produzida.

Mesmo que sejam poucas as ocorrências dos desvios semânticos identificados nesse grupo, os exemplos citados no parágrafo anterior reforçam a ideia de que a gramaticalização também é um processo interno da língua.

A maior parte dos desvios coletados de todo o corpus que utilizei para análise e posterior desenvolvimento deste tabalho aponta para um processo de gramaticalização envolvendo, principalmente, a estrutura zu+verbo no infinitivo, bem como seu correspondente morfológico para+infinitivo. Segundo a definição (capítulo 4) para a utilização das estruturas alemãs estudadas, a forma zu+verbo no infinitivo é a que apresenta um maior número de contextos semânticos para sua aplicação. A diversidade semântica dessa estrutura confere maior flexibilidade quanto ao seu uso, criando, assim, maiores possibilidades de aplicações em novos contextos até então não definidos pelo Hochdeutsch. Consequentemente a ocorrência do processo de gramaticalização 
envolvendo essa estrutura é, sem dúvida, muito maior quando suas possibilidades de usos são comparadas às possibilidades das demais estruturas citadas. Estas apresentamse muito mais restritas e definidas. 


\section{Referências bibliográficas}

BARANOW, Ulf Gregor. Studien zum Deutsch - Portugiesischen Sprachkontakt in Brasilien". Doutorado em Lingüística Germânica e Filosofia . Ludwig Maximilian Universität München, LMU, Alemanha, 1972.

BARROSO, Paulo Henrique de Oliveira. Vias de abstratização do verbo BUSCAR no Português brasileiro culto: interface entre gramaticalização e gêneros do discurso. Dissertação de Mestrado. Programa de Filologia e Língua Portuguesa. São Paulo: FFLCHUSP, 2008.

BATISTA, Adriana Santos. Rotas de Gramaticalização no português: estruturas tirarque noportuguês culto de São Paulo. Relatório Final de Pesquisa de Iniciação Científica entregue à Fapesp (processo 07/01331-0). São Paulo, 2008.

BECHARA, Evanildo. Moderna Gramática Portuguesa. Rio de Janeiro: Lucerna, 1999.

BICKERTON, D. The language bioprogram hypothesis. The Brain and Behavioral Sciences 7, 2, 1984, p. 173-221.

BRAGA, Maria Luiza. As orações encaixadas no dialeto carioca. Conferência apresentada em concurso para Professor Titular junto ao Departamento de Línguística e Filologia da Faculdade de Letras da Universidade Federal do Rio de Janeiro, 1999.

CASTILHO, Ataliba T. \& PRETI, Dino (orgs.) A linguagem falada culta na cidade de São Paulo - Materiais para seu estudo, vol. I - Elocuções formais. São Paulo: T. A. Queiroz, 1986.

CEGALlA, Domingos Paschoal. Novíssima Gramática da Língua Portuguesa. São Paulo: Nacional, 2005.

CEREJA, William Roberto e MAGALHÃES, Thereza Cochar. Português: Linguagens. São Paulo: Ed. Atual, 2004.

CIPRO NETO, Pasquale e INFANTE, Ulisses. Gramática da Língua Portuguesa. São Paulo: Scipione, 1997.

COUTO, Hildo Honório. Introdução ao estudo das línguas crioulas e pidgins. Brasília: editora UnB, 1996.

CUNHA, Celso \& CINTRA, Lindley. Nova Gramática do Português Contemporâneo. Rio de Janeiro: Nova Fronteira, 1985.

DEFENDI, Cristina Lopomo. A reduplicação no português culto falado em São Paulo: possível gramaticalização?. Dissertação de Mestrado. São Paulo: Universidade de São Paulo, 2008.

DIAS, Augusto Epiphanio da Silva. Sintaxe Histórica Portuguesa. São Paulo: Livraria Clássica Editora, 1970. 
DIAS, Nilza Barrozo. As cláusulas de finalidade. São Paulo: Universidade Estadual de Campinas, 2001.

DREHER, Martin N. Igreja e germanidade. São Leopoldo: Sinodal, 2003.

FOUQUET, Carlos. O imigrante alemão e seus descendentes no Brasil - 1808 -1824 1974. São Paulo: Instituto Hans Staden, 1974.

GONÇALVES, Sebastião Carlos Leite. Gramaticalização, modalidade epistêmica e evidencialidade: um estudo de caso no Português do Brasil. Campinas: IEL/UNICAMP,2003.

GONÇALVES, Sebastião Carlos Leite, LIMA-HERNANDES, Maria Célia, CASSEBGALVÃO, Vânia Cristina. Introdução à gramaticalização. São Paulo: editora Parábola, 2007.

HEINE, CLAUDI \& HÜNNEMEYER. Grammaticalization: a Conceptual Framework. Chicago: University of Chicago Press, 1991.

HEINE \& KUTEVA. Language Contact and Grammatical Change. Cambrigde: Cambrigde University Press, 2006.

HEINE, Bernd \& MIYASHITA, Hiroyuki. Grammaticalization and language contact: auxiliation in the languages of Europe. 2007

LIMA-HERNANDES, Maria Célia. Gramaticalização de Combinação de Cláusulas: Orações de tempo no português do Brasil. São Paulo: Universidade de São Paulo, 1998.

LIMA-HERNANDES, Maria Célia \& FROMM, Guilherme. Domínios de Linguagem $V$ - Diálogo entre a universidade, a escola e a sociedade. São Paulo: Editora Plêiade, 2005.

LYRA, Marcelo. Documentário com Ficção revela M. Leopoldina. O Estado de São Paulo, São Paulo, pg. D2. Data: 30-01-2001.

NEVES, Maria Helena de Moura. Gramática de usos do português. São paulo: Ed. Unesp, 2002.

NEVES, Maria Helena de Moura; BRAGA, Maria Luiza. Hipotaxe e gramaticalização. Uma análise das construções de tempo e de condição. DELTA. Documentação de Estudos em Lingüística Teórica e Aplicada São Paulo, v. 14, n. esp., p. 191-208, 1998.

OXFORD, R. Language Learning Strategies: what every teachershould know. Nova York: Newbury House Publishers, 1990.

POPLACK, Shana. Linguistic variation and language contact. In: PRESTON, D. (ed.). American dialect research: an anthology celebrating the $100^{\text {th }}$ aniversary of the American Dialect Society. Philadelphia: University of Pennsylvania Press, 1991.

PRETI, Dino (2004). Estudos de língua oral e escrita. Rio de Janeiro: Editora Lucerna. 
REIMANN, Monika. Grundstufen - Grammatik für Deutsch als Fremdsprache: Erklärung und Übungen. Ed. Max Hueber Verlag. ISBN:3-19-011575-3.0, 2005.

REZAGLI, Caroline Calderon \& DEL GROSSI, Beatriz. Panorama sobre a história da imigração alemã: um olhar sobre São Paulo. Monografia apresentada ao curso Sociolinguísticado Português Brasileiro: Variação e Mudança, 2007.

ROTERMUND, Wilhelm. Die ersten deutschen Schulbücher. Aus Das Schulbuch, Ausgabe Juli 1917. Manuscrito s/d

SAID ALI, Manuel. Gramática histórica da Língua Portuguesa. Rio de Janeiro: Melhoramentos, 1971.

SARTIN, Elisângela Baptista de Godoy. Gramaticalização de combinações de orações: estruturas para+infinitivo no português. Dissertação de mestrado. São Paulo: Universidade de São Paulo, 2008.

SIRIANE, Silvia Cristina Lambert. Uma São Paulo alemã: vida quotidiana dos imigrantes germânicos na região da capital (1827 - 1889). São Paulo: Arquivo do Estado, Imprensa Oficial do Estado, 2003.

SPAZIANI, Lídia. Deslizamentos gramaticais da estrutura fora+que. Trabalho apresentado no VI Simpósio Internacional do Projeto Caipira. São Paulo: USP, 2007.

TARALLO, F. \& ALKMIN, T. (1987) Falares crioulos. Linguas em contato. São Paulo: Editora Ática.

TRAUGOTT \& HEINE. Approaches to grammaticalization. Vol I. Philadelphia: John Benjamins Publishing Company, 1991.

WELKER, Herbert Andreas. Gramática Alemã. Brasília: Fundação Universidade de Brasília. 2. edição: Editora Universidade de Brasília, 2008.

WILLEMS, Emílio. A aculturação dos alemães no Brasil. 2. ed. São Paulo: Companhia Editora Nacional, 1980.

\section{Referências eletrônicas:}

HARPAZ, Yehouda. "Myths and misconceptions in Cognitive Science". Human Cognition in the Human Brain. <http://human-brain.org/myths.html>. Online. Nov 1, 2003.

http://www.dw-world.de/article/0,4753666,00.html - Acesso em abril de 2009.

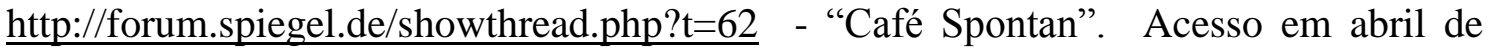
2009. 
SAOUB, Esther. Alles ist möglich, so lange es dezent passiert. Kategorie: Auslandskorrespondenten, Naher Osten, Saudi-Arabien-Reise. http://blog.tagesschau.de/ Acesso em 28 de setembro de 2009.

SAOUB, Esther. Das grösste Frauengefängnis der Welt. Kategorie: Auslandskorrespondenten, Naher Osten, Saudi-Arabien-Reise. http://blog.tagesschau.de/ Acesso em 29 de setembro de 2009. 


\section{Anexos:}

1nfpn (56) (...)eu fiquei bem distante de alemães...porque para aprender a língua você precisa falar com o povo(...) - inf. 4 -

1nfps (57)(...) eu acho que na Alemanha ... nas Universidades ... não tem muitos lugares para estudar português, né?(...) - inf.5 1

1nfps (58)(...) então, é, no curso a mesma coisa ... o que eu fiz para entregar(...) - inf.3 1nepn (59)(...) eu pediu alguém para dar uma olhada(...) - inf.3

1ndns $(60)(. .$.$) de fazer uma coisa melhor...C: interessante...isso eu nunca tinha$ ouvido...M: mas, mas... só pra completar talvez, mas às vezes, eu sou aqui responsável pelos projetos culturais.(..) - inf. 3

1nens $(61)(\ldots)$ por isso até hoje, né, eu entender mais com eu falar, né? ler, é claro, é um problema, mas também pra conversar é um pouco difícil...língua portuguesa já/já difícil(...) - inf. 2 - sujeito

1nfps $(62)(. .$.$) aprendo...às vezes eu, por exemplo, pouco mais (?) imperfeito, perfeito,$ por exemplo, né? mas só pra falar e ouvir, né?(...) - inf.2

1nfnn (63)(...)mais fácil...porque você veja... às vezes só pra ler um palavra, por exemplo, né (...) - inf.2

1nann (64)(...)língua português tem, é, também um pouco de influência pra inglês, por exemplo, muitas palavras, né...também da língua francesa ... e esse coisas...pra falar depende sempre também a pessoas(...) - inf.4

1nens (65)(...)que eu não trabalho como professor aqui, mas eu acho que pra trabalha é $\operatorname{igual}(\ldots)-\inf .2$ 
1nfps $(66)(. .$.$) eles tem bastante idade...eles já chegou aqui pra visita...uma gosta, outra$ já non(...) - inf.2

2ofps (67)(...)ah, isso é difícil dizer ... eu escolhi o Brasil pra...eu vim de propósito, né?...queria vim ao Brasil... morar aqui... eu gosto... - inf.4

3nfps (68)(...)então para isso .... após o trabalho na universidade fui para entrevista(...) $-\inf .3$

3(69)(...)Eu não gosta disso. Instituto eu acho...bastante ... e também eu acho não bom para alemãos, por exemplo. eles reunion para clubes, ou qualquer coisa... - inf.2

3(70)(...) tranquila, sem responsabilidade para nada(..) - inf.4

3(71)(...) eu fui uma vez lá pra casamento do meu filha (...) - inf.2

2sfps (72)(...)isso é minha experiência aqui...tudo faça para...para...as coisas acontecer(...) - inf.4

3dfpn (73) (...)eu trabalhei, ãã, volunta/não voluntariamente, não, como free lancer para uma revista brasileira-alemã, então para isso (acontecer).... - inf.4

1nfpn (74) (...)eu fiquei bem distante de alemães...porque para aprender a língua você precisa falar com o povo(...) - inf.5

1naps (75) (...) eu vim pra cá com, tipo, curso básico de português, mas eu vim pra/ fui pra Porto Alegre, fiz um estágio no Instituto Goethe onde todo mundo falava alemão então não ajudava muito pra... aprender o português ... - inf.3

(76) Bitte einloggen, um zu antworten! (Por favor, acesse para responder!) (Deustch Welle)

(77) Wir müssen lernen, um zu verstehen!!! (Nós podemos aprender, para entender!!) (Deustch Welle) 
(78) Gekommen Um Zu Bleiben (Chegar para ficar.) (propaganda de produto alemão in Deustch Welle)

(79) Zurückgekommen... um zu bleiben. (Voltar para ficar.) (Deustch Welle)

(80) (...) geboren um zu sterben. (Nascer para morrer.) (Deustch Well)

(81) Ich kam genau an, um zu einigen Leuten im Netz zu fragen ... (Eu cheguei, para perguntar a algumas pessoa na rede...) (Deustch Welle)

(82) Anmelden oder registrieren um zu kommentieren. (Anuncie ou registre para comentar) (propaganda in Deustch Welle)

(83) Ich Bin Gebildet Genug . . . um zu lieben und zu trauern: Wilhelm Meister's Apprenticeship in Mourning ( $\mathrm{Eu}$ compus muito ... para viver e para sonhar...) (entrtevista em jornal alemão - Deuscth Welle)

(84) Wanderers zu stecken, einen $\underline{\text { Schlitten über den Sand ziehen, einen Benzinkocher }}$ anwerfen, gefriergetrocknete Expeditionsnahrung zubereiten und verspeisen zu lassen, um dann das total entspannte Foto des Tages $z u$ schießen? (...mostrar turistas, colocar um trenó sobre a areia, acender um fogão a gás, preparar a comida congelada da expedição, só para tirar uma foto normal do dia?) (Deustch Welle)

(85) "Viren brauchen Lebewesen, um zu überleben und sich zu vermehren. (Precisa de um ser vivo, para sobreviver e para multiplicar-se.) (Deustch Welle - Acesso em)

(86) Um die Ausdauer zu verbessern, jogge ich. (Para a resistência melhorar, eu jogo.) (Deustch Welle)

(87) Dort hat man viele Meldungen auf einen Blick und muss nicht lange scrollen um einen Überblick zu gewinnen. (http://forum.spiegel.de/showthread.php?t=62) $19 / 12 / 2008$ 
Lá você tem muitas mensagens num piscar de olhos e não deve ser longo, a fim de obter uma panorâmica

(88)Obwohl von mir gelesen, ist es komisch zum Party-Smalltalk über einen Carmelengo zu parlieren, der eine Antimaterie-Explosion über Rom herberführt, um dann mit einem $\quad$ Fallschirm abzuspringen. (http://forum.spiegel.de/showthread.php?t=62)

Apesar de lido por mim, é engraçado para Party-Smalltalk falar sobre um Carmelengo que trouxe uma explosão de anti-matérias sobre a Roma, para depois saltar de páraquedas

(89)Gerade den Reporter beim ewig sinnlos gehypten Second Live abgezogen - um dann sofort beim nächsten Hype einzusteigen. (http://forum.spiegel.de/showthread.php?t=62)

Especialmente quando o repórter eliminou para sempre o sensacionalista Second Life para poder imediatamente entrar na próxima campanha publicitária

(90) (...)Keeper Sacha Burchert musste jeweils herauseilen um für seine indisponierten Verteidiger zu retten(...) (http://www.dw-world.de/dw/article) Keeper Sacha Burchert precisava correr para salvar o seu indisposto Defensor (...)

(91)Kleine Empfehlung als Sekundärliteratur, um die Wartezeit zu verkürzen: (...) (http://forum.spiegel.de/showthread.php?t=62)

Pequena recomendação como literatura secundária, para encurtar o tempo de espera 
(92) Dann vielleicht nach Rom. Dort gibt es Vespas und einen historischen Frauenraub $z u$ sehen. (Lá, há vespas e uma histórica prisão de mulheres para ver.) (http://blog.tagesschau.de)

(93) Die Ausstellung ist bis 20. April im Museum "Complesso del Vittoriano" in Rom zu sehen. (Ver a exposição até 20 de abril no museu "Complesso del Vittoriano" em Roma.) (Deustch Welle)

(94) Als Symbol für die Kunst, Design und Funktion zu vereinen, wird etwa die Vespa GS 150 aus dem Jahr 1955 gefeiert. (Concentrar como símbolo da arte, design e funcionalidade...) (Deustch Welle)

(95) Auf Spruchbändern war zum Beispiel "Freihandel = Weltwirtschaftskrise" zu lesen und "keine Spekulation mit Nahrung". (Ler em banners, por exemplo,"livre comércio = crise econômica global“ e „nenhuma especulação com os alimento“) (Deustch Welle)

(96) Auf Transparenten war zu lesen: "Menschen vor Profit", "Raus aus Irak und Afghanistan" sowie "Jobs, Gerechtigkeit, Klima". (Foi ler em cartazes: "As pessoas antes dos lucros", "Saiam do Iraque e do Afeganistão" e "postos de trabalho, a justiça, o clima" (http://blog.tagesschau.de)

(97) Man wolle sich bemühen, den G20-Gipfel in London mit konkreten Vorschlägen zu verlassen, sagte Biden. (Seria tentar sair da cimeira do G20 em Londres, com propostas concretas, "Biden disse.) (Deustch Welle)

(98) Ganze vier Tage brauchte im Sommer 2008 das deutsche Forschungsschiff $\underline{\text { Polarstern }}(. .$.$) und damit in gut zwei Monaten den Nordpol komplett umrundete. (Todos$ os quatro dias serão necessários, no verão de 2008, ao navio de investigação alemão Polarstern, (...), e para que complete a circunavegação pelo pólo norte em bons dois meses. (Deutsch Welle) 
(99) "Da muss man sehr genau nachrechnen, damit man nicht nur ins Eis hineinfährt, sondern auch wieder heraus. (...)" ("Então você tem que calcular muito cuidadosamente para que você não caia dentro do gelo, mas também volte para fora. (,,,)"(Deustch Welle)

(100) Darüber wird eine Plastiktüte gezogen, damit der Schweiß in der Socke und der Schuh trocken bleibt. (Por isso usou um saco de plástico, para que o suor da meia e do sapato seque. (Deustch Welle)

(101) Professor Uhlenbruck empfiehlt eine "Fitness wie beim Marathontraining", mit Joggen und Kraftübungen, damit der Körper optimal durchblutet sei. (Professor Uhlenbruck recomenda um "exercícios como o treinamento para uma maratona",com corrida e musculação para que o corpo tenha uma ótima circulação sanguínea.) (Deustch Welle)

(102) Zum einen gebe es also keine Viren in der arktischen Luft, zum anderen stimuliere der Kältereiz die Atemwege und mache sie damit gewissermaßen fit. (Em primeiro lugar, não há, portanto, nenhum vírus no ar ártico, segundo, o estímulo frio estimula o sistema respiratório, e para eles se tornarem aptos por assim dizer.) (Deustch Welle)

(103) Wir freuen uns, unser Angebot mit der deutschsprachigen Fassung der Community nun auszubauen, und damit der wachsenden Zahl unser deutschsprachigen Nutzer Rechnung zu tragen. (Estamos muito satisfeitos por expandir nossa oferta com a versão alemã da comunidade agora, e para trazer um crescente número de nossos falantes alemães.) (Deustch Welle) 
(104) Ich bliebe von den Deutsch entfern denn um eine Sprache kennenzulernen musst du mit von gesprechen.

(...)eu fiquei bem distante de alemães...porque para aprender a língua você precisa falar com o povo(...) - inf 4

(105) Ich glaube dass in Deutschland na den Universitäten wenig Platz ist um Portugiesisch zu lernen.

(...) eu acho que na Alemanha ... nas Universidades ... não tem muitos lugares para estudar português, né?(...) - inf. 5

(106) dann, der Kurs ist immer das gleiche...was ich getan habe zu liefern

(...) então, é, no curso a mesma coisa ... o que eu fiz para entregar(...) - inf. 3

(107) Ich batt jemand es anzuschauen

(...) eu pediu alguém para dar uma olhada(...) - inf. 3

(108) Aber um es vielleicht zu beenden aber manchmal ich bin verantwortlich für kulturelle Projekte

M: mas, mas... só pra completar talvez, mas às vezes, eu sou aqui responsável pelos projetos culturais.(..) - inf. 3

(109) Also bis Heute vorstehe ich mehr alzusprechen lesen ist ein Problem aber auch

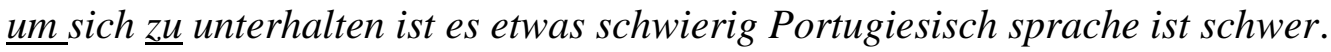


(...)por isso até hoje, né, eu entender mais com eu falar, né? ler, é claro, é um problema, mas também pra conversar é um pouco difícil...língua portuguesa já/já difícil(...)- inf.2

(110) (...)lernen ... manchmal habe ich zum Beispiel etwas mehr (?) unvollkommen, perfekte, zum Beispiel, nicht wahr? sondern nur zu reden und zu hören, nicht wahr?(...) (...)aprendo...às vezes eu, por exemplo, pouco mais (?) imperfeito, perfeito, por exemplo, né? mas só pra falar e ouvir, né?(...) - inf. 2

(111) Leichter denn schau hier manchmal zum Beispiel nur um ein Wort zu sprechen. mais fácil..porque você veja...às vezes só pra ler um palavra, por exemplo, né (...)-inf.2

(112) Die Portugiesisch Sprache hat wenig Einfluz in Englisch zum Beispiel viele Wörter auch Französisch und um diese sachen zu sprechen kommt es immer auf die Personen.

(...)língua português tem, é, também um pouco de influência pra inglês, por exemplo, muitas palavras, né...também da língua francesa ... e esse coisas...pra falar depende sempre também a pessoas (...) - inf. 4

(113)(...) ich arbeite nicht als Lehrer hier, aber ich glaube um hier zu arbeiten ist es gleich.

(...)que eu não trabalho como professor aqui, mas eu acho que pra trabalha é igual(...) $\inf .2$ 
(114) Sie haben schon ein gewisses alter sie kammen hierher um eine Besuch zu zu machen.

(...) eles tem bastante idade...eles já chegou aqui pra visita...uma gosta, outra já non(...) - inf. 2

(115) Das ist schwierig zu sagen... ich habe Brazilien aus gesucht ich bin bewusst gekommen. Ich wollte nach Brasil hier wohnen mir gefällte es ist alles gut aber ich kam nicht sagen fallt ist nicht züruckgehen aber ich kam auch hier bleiben.

(...)ah, isso é difícil dizer ... eu escolhi o Brasil pra...eu vim de propósito, né?...queria vim ao Brasil... morar aqui... eu gosto... - inf. 4

(116) (...)dann ist diese... nach der Arbeit an der Universität ging für das $\operatorname{Interview}(\ldots)$

(...)então para isso .... após o trabalho na universidade fui para entrevista (...) - inf. 3

(117) Ich finde dass es viel Deutsch zum Beispiel nicht gut ist sich im Klub oder Erliches zu treffen. Kürche ja aber... ich schätze nicht und war auch nie dafür

(...)Eu não gosta disso. Instituto eu acho...bastante ... e também eu acho não bom para alemãos, por exemplo. eles reunion para clubes, ou qualquer coisa... - inf. 2

(118) (...)ruhig, keine Verantwortung für alles(...)

(...)C: eu gostaria de saber como você definiria o povo brasileiro...qual a maior característica que faz com ele seja bem diferente dos alemães...G: tranquila, sem responsabilidade para nada(..) - inf. 3 
(119) (...)ich war einmal dort für die Hochzeit meiner Tochter(...)

(...) eu fui uma vez lá pra casamento do meu filha (...) - inf. 2

(120) Das ist meine Erfahrung hier (...) ich mache alles um die Sachen zu machen. Ich arbeite nicht als Lehrer hier aber ich glaube um hier zu arbeiten ist es Gleich.

(...)isso é minha experiência aqui...tudo faça para...para...as coisas acontecer(...) - inf. 4 (121) Ich arbeitest nicht Freiwilig sondern als Free-lancer vier eine Deutsch Brasilianische Zeitschrift also um das zu tun nach der Arbeit andern Universität bin ich

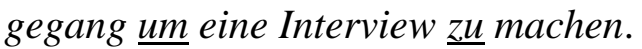

(...)eu trabalhei, ãã, volunta/não voluntariamente, não, como free lancer para uma revista brasileira-alemã, então para isso (acontecer).... após o trabalho na universidade fui para (fazer uma) entrevista(...) - inf. 4

(122) Das ist meine "Experiência” hier (...) ich mache alles um die Sachen zu machen. Ich arbeite nicht als Lehrer hier aber ich glaube um hier zu arbeiten ist es Gleich.

(...)isso é minha experiência aqui...tudo faça para...para...as coisas acontecer(...) - inf.4

(123) Ich bliebe von den Deutsch entfern denn um eine Sprache kennenzulernen musst du mit von gesprechen.

(...)eu fiquei bem distante de alemães...porque para aprender a língua você precisa falar com o povo(...) - inf. 5 
